Prepared in cooperation with the City of Fayetteville, Arkansas, and Beaver Water District

Ambient Conditions and Fate and Transport Simulations of Dissolved Solids, Chloride, and Sulfate in Beaver Lake, Arkansas, 2006-10

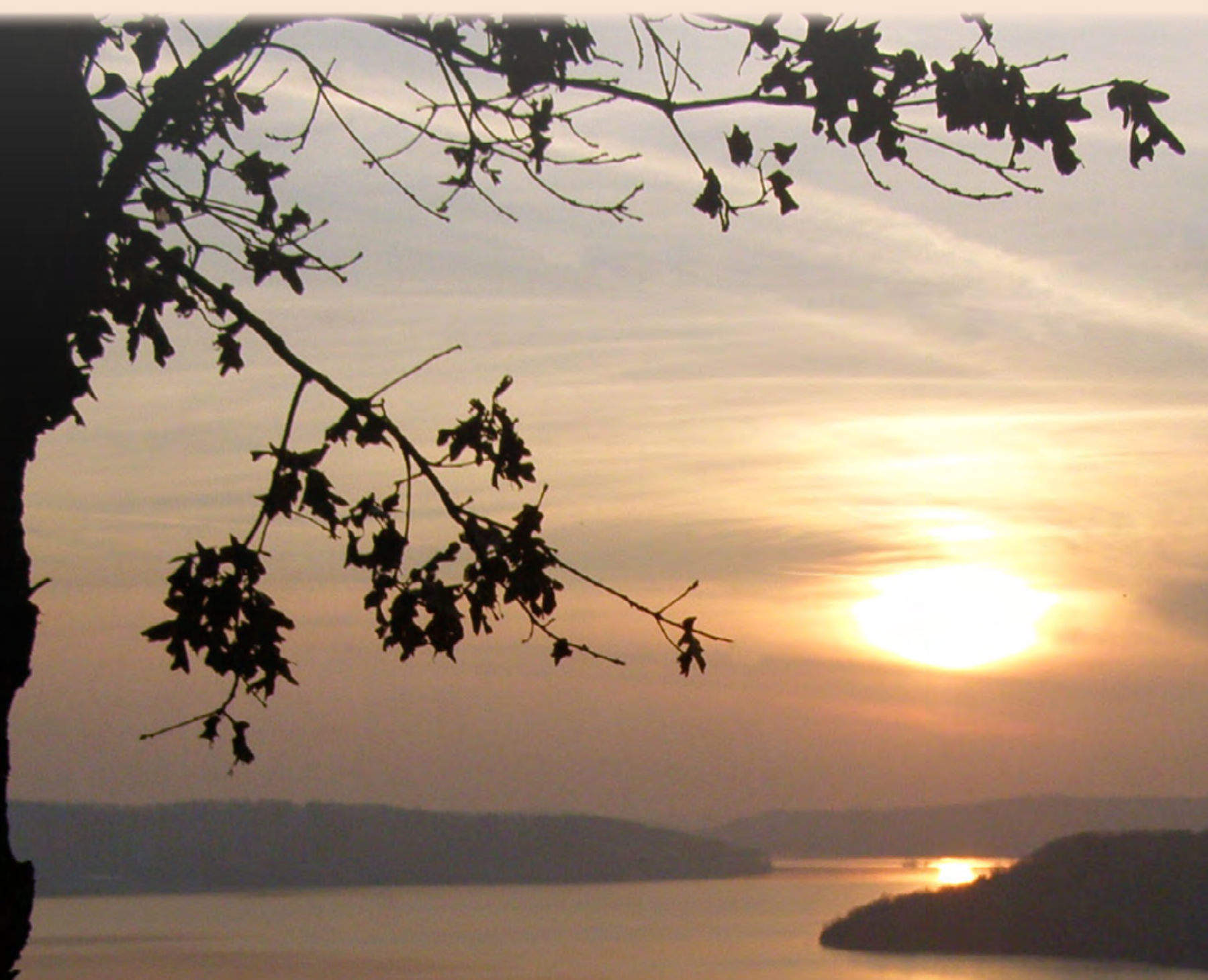

Scientific Investigations Report 2013-5019

U.S. Department of the Interior U.S. Geological Survey 
Cover:

Photo by Robert Morgan, Beaver Water District. 


\section{Ambient Conditions and Fate and Transport Simulations of Dissolved Solids, Chloride, and Sulfate in Beaver Lake, Arkansas, 2006-10}

By W. Reed Green

Prepared in cooperation with the City of Fayetteville, Arkansas, and Beaver Water District

Scientific Investigations Report 2013-5019 


\section{U.S. Department of the Interior \\ KEN SALAZAR, Secretary}

\section{U.S. Geological Survey \\ Suzette M. Kimball, Acting Director}

U.S. Geological Survey, Reston, Virginia: 2013

This and other USGS information products are available at http://store.usgs.gov/
U.S. Geological Survey
Box 25286, Denver Federal Center
Denver, CO 80225
To learn about the USGS and its information products visit http://www.usgs.gov/
1-888-ASK-USGS

Any use of trade, product, or firm names is for descriptive purposes only and does not imply endorsement by the U.S. Government.

Although this report is in the public domain, permission must be secured from the individual copyright owners to reproduce any copyrighted materials contained within this report.

Suggested citation:

Green, W. Reed, 2013, Ambient conditions and fate and transport simulations of dissolved solids, chloride, and sulfate in Beaver Lake, Arkansas, 2006-10: U.S. Geological Survey Scientific Investigations Report 2013-5019, 50 p. 


\section{Contents}

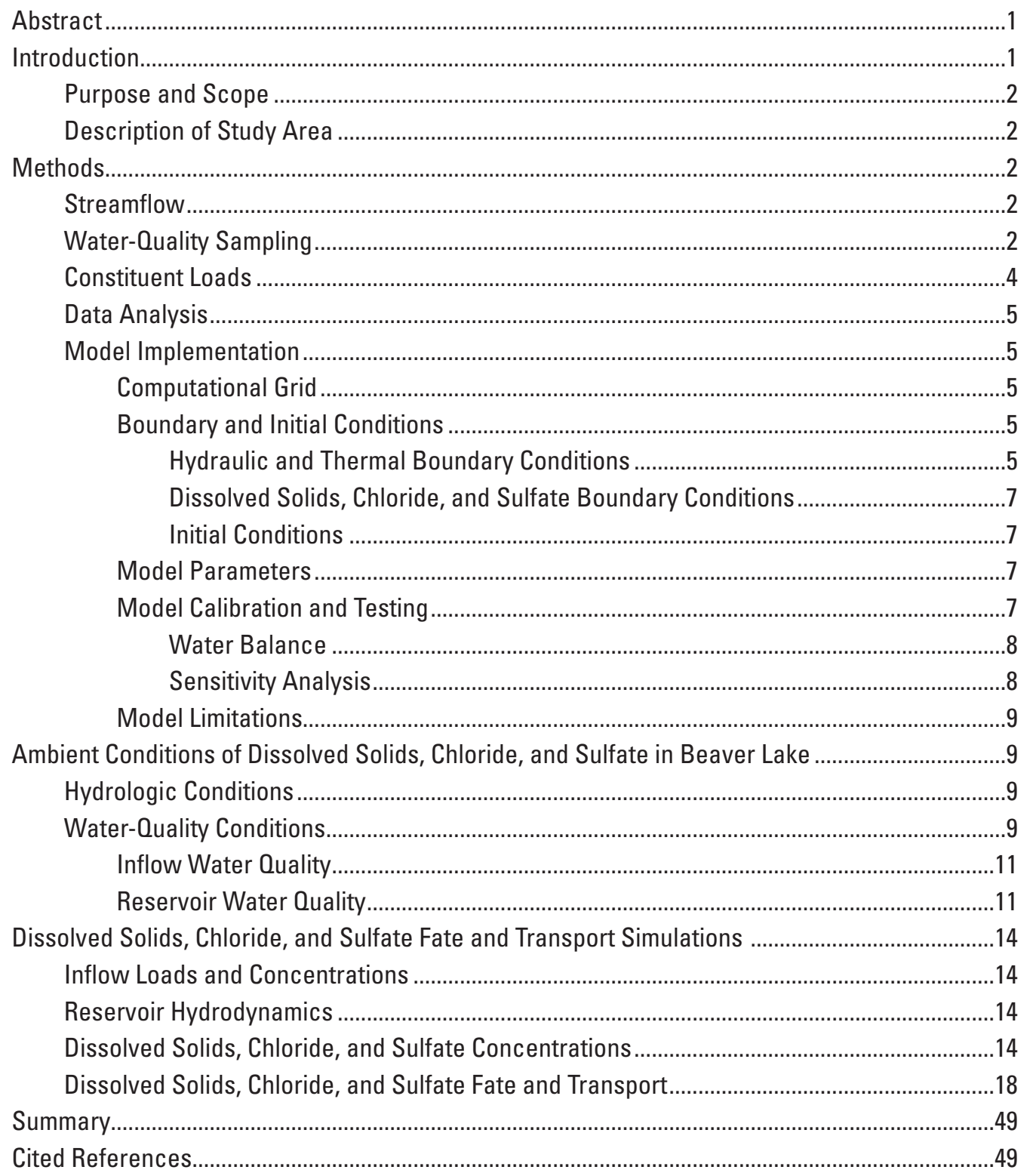




\section{Figures}

1. Map showing Beaver Lake study area, Arkansas, with locations of water-quality sampling sites.

2. Composite showing side view $(A)$, top view $(B)$, and face view from the dam (C) of the computational grid of Beaver Lake, Arkansas, used in the CE-OUAL-W2 model.

Graphs showing:

3. Simulated and measured water-surface elevations near Beaver Lake dam, Arkansas, January 2006 through December 2010.

4. Mean daily streamflow for White River (site S1), Richland Creek (site S2), and War Eagle Creek (site S3), and hourly outflow at Beaver Lake dam.

5. Distribution of dissolved solids, chloride, and sulfate concentrations for White River (site S1), Richland Creek (site S2), and War Eagle Creek (site S3), 2006-10.

6. Distribution of dissolved solids, chloride, and sulfate concentrations 2 meters $(\mathrm{m})$ below the surface at lake sites $L 1-L 5$, $L 9$, and $L 10,2006-10$

7. Time-series distributions of measured and S-LOADEST estimated dissolved solids, chloride, and sulfate concentrations at White River (site S1)

8. Time-series distributions of measured and S-LOADEST estimated dissolved solids, chloride, and sulfate concentrations at Richland Creek (site S2)

9. Time-series distributions of measured and S-LOADEST estimated dissolved solids, chloride, and sulfate concentrations at War Eagle Creek (site S3).

10. Selected simulated and measured water-temperature profiles for Beaver Lake at Highway 412 bridge near Eureka Springs, Arkansas (site L5, segment 35 ).

11. Simulated and measured dissolved solids concentrations 2 meters below the surface in Beaver Lake, Arkansas.

12. Simulated and measured dissolved solids concentrations 2 meters above the bottom in Beaver Lake, Arkansas.

13. Simulated and measured chloride concentrations 2 meters below the surface in Beaver Lake, Arkansas

14. Simulated and measured chloride concentrations 2 meters above the bottom in Beaver Lake, Arkansas

15. Simulated and measured sulfate concentrations 2 meters below the surface in Beaver Lake, Arkansas

16. Simulated and measured sulfate concentrations 2 meters above the bottom in Beaver Lake, Arkansas

17. Dissolved solids, chloride, and sulfate concentrations 2 meters below the surface at model segments 2, 5, 48, 14, 16, 23 and 35 from baseline model and increased loading scenarios from both White River near Fayetteville, Arkansas, (site S1) and War Eagle Creek near Hindsville, Ark. (site S3)

18. Average daily dissolved solids for the period January 2006 through December 2010 from White River near Fayetteville, Arkansas, (site S1) only. 
19. Average daily dissolved solids for the period January 2006 through December 2010 from War Eagle Creek near

Hindsville, Arkansas, (site S3) only.....

20. Average daily dissolved solids for the period January 2006 through December 2010 from both White River near Fayetteville, Arkansas, (site S1) and War Eagle Creek near Hindsville, Ark. (site S3).

21. Average daily chloride concentrations for the period January 2006 through December 2010 from White River near Fayetteville, Arkansas, (site S1) only .....

22. Average daily chloride concentrations for the period January 2006 through December 2010 from War Eagle Creek near Hindsville, Arkansas, (site S3) only.

23. Average daily chloride concentrations for the period January 2006 through December 2010 from both White River near Fayetteville, Arkansas, (site S1) and War Eagle Creek near Hindsville, Ark. (site S3).

24. Average daily sulfate concentrations for the period January 2006 through December 2010 from White River near Fayetteville, Arkansas, (site S1) only

25. Average daily sulfate concentrations for the period January 2006 through December 2010 from War Eagle Creek near Hindsville, Arkansas, (site S3) only.

26. Average daily sulfate concentrations for the period January 2006 through December 2010 from both White River near Fayetteville, Arkansas, (site S1) and War Eagle Creek near Hindsville, Ark. (site S3)

\section{Tables}

1. Streamflow and water-quality sites for Beaver Lake, Arkansas

2. Parameters and values used in the CE-QUAL-W2 model of Beaver Lake, January 2006 to December 2010

3. Statistics measuring error between measured and S-LOADEST estimated dissolved solids, chloride, and sulfate concentrations at White River (S1), Richland Creek (S2), and War Eagle Creek (S3)

4. CE-QUAL-W2 model calibration evaluation statistics for water temperature, dissolved solids, chloride, and sulfate for Beaver Lake sites, January 2006 through December 2010

5. Average daily dissolved solids, chloride, and sulfate concentrations for baseline condition and increasing loading factor scenarios from White River near Fayetteville (site S1) only, for the period January 2006 through December 2010.

6. Average daily dissolved solids, chloride, and sulfate concentrations for baseline condition and increasing loading scenarios from War Eagle Creek (site S3) only, for the period January 2006 through December 2010.

7. Average daily dissolved solids, chloride, and sulfate concentrations for baseline condition and increasing loading factor scenarios from White River near Fayetteville (site S1) and War Eagle Creek near Hindsville (site S3), for the period January 2006 through December 2010. 


\section{Conversion Factors}

SI to Inch/Pound

\begin{tabular}{|c|c|c|}
\hline Multiply & By & To obtain \\
\hline \multicolumn{3}{|c|}{ Length } \\
\hline centimeter $(\mathrm{cm})$ & 0.3937 & inch (in.) \\
\hline millimeter $(\mathrm{mm})$ & 0.03937 & inch (in.) \\
\hline meter $(\mathrm{m})$ & 3.281 & foot $(\mathrm{ft})$ \\
\hline kilometer $(\mathrm{km})$ & 0.6214 & mile (mi) \\
\hline kilometer $(\mathrm{km})$ & 0.5400 & mile, nautical (nmi) \\
\hline meter $(\mathrm{m})$ & 1.094 & yard $(y d)$ \\
\hline \multicolumn{3}{|c|}{ Area } \\
\hline square kilometer $\left(\mathrm{km}^{2}\right)$ & 247.1 & acre \\
\hline \multicolumn{3}{|c|}{ Volume } \\
\hline cubic meter $\left(\mathrm{m}^{3}\right)$ & 6.290 & barrel (petroleum, 1 barrel $=42$ gal) \\
\hline liter (L) & 33.82 & ounce, fluid (fl. oz) \\
\hline liter $(\mathrm{L})$ & 2.113 & pint (pt) \\
\hline liter $(\mathrm{L})$ & 1.057 & quart (qt) \\
\hline liter $(\mathrm{L})$ & 0.2642 & gallon (gal) \\
\hline cubic meter $\left(\mathrm{m}^{3}\right)$ & 0.0002642 & million gallons (Mgal) \\
\hline liter $(\mathrm{L})$ & 61.02 & cubic inch $\left(\mathrm{in}^{3}\right)$ \\
\hline cubic meter $\left(\mathrm{m}^{3}\right)$ & 35.31 & cubic foot $\left(\mathrm{ft}^{3}\right)$ \\
\hline cubic meter $\left(\mathrm{m}^{3}\right)$ & 1.308 & cubic yard $\left(\mathrm{yd}^{3}\right)$ \\
\hline \multicolumn{3}{|c|}{ Flow rate } \\
\hline cubic meter per second $\left(\mathrm{m}^{3} / \mathrm{s}\right)$ & 70.07 & acre-foot per day (acre-ft/d) \\
\hline \multicolumn{3}{|c|}{ Mass } \\
\hline $\operatorname{gram}(\mathrm{g})$ & 0.03527 & ounce, avoirdupois (oz) \\
\hline kilogram (kg) & 2.205 & pound avoirdupois (lb) \\
\hline
\end{tabular}

Temperature in degrees Celsius $\left({ }^{\circ} \mathrm{C}\right)$ may be converted to degrees Fahrenheit $\left({ }^{\circ} \mathrm{F}\right)$ as follows:

${ }^{\circ} \mathrm{F}=\left(1.8 x^{\circ} \mathrm{C}\right)+32$

Vertical coordinate information is referenced to the National Geodetic Vertical Datum of 1929 (NGVD 1929)

Altitude, as used in this report, refers to distance above the vertical datum. 


\title{
Ambient Conditions and Fate and Transport Simulations of Dissolved Solids, Chloride, and Sulfate in Beaver Lake, Arkansas, 2006-10
}

\author{
By W. Reed Green
}

\section{Abstract}

Beaver Lake is a large, deep-storage reservoir located in the upper White River Basin in northwestern Arkansas, and was completed in 1963 for the purposes of flood control, hydroelectric power, and water supply. Beaver Lake is affected by point and nonpoint sources of minerals, nutrients, and sediments. The City of Fayetteville discharges about half of its sewage effluent into the White River immediately upstream from the backwater of the reservoir. The City of West Fork discharges its sewage effluent into the West Fork of the White River, and the City of Huntsville discharges its sewage effluent into a tributary of War Eagle Creek.

A study was conducted to describe the ambient conditions and fate and transport of dissolved solids, chloride, and sulfate concentrations in Beaver Lake. Dissolved solids, chloride, and sulfate are components of wastewater discharged into Beaver Lake and a major concern of the drinking water utilities that use Beaver Lake as their source. A two-dimensional model of hydrodynamics and water quality was calibrated to include simulations of dissolved solids, chloride, and sulfate for the period January 2006 through December 2010. Estimated daily dissolved solids, chloride, and sulfate loads were increased in the White River and War Eagle Creek tributaries, individually and the two tributaries together, by $1.2,1.5,2.0,5.0$, and 10.0 times the baseline conditions to examine fate and transport of these constituents through time at seven locations (segments) in the reservoir, from upstream to downstream in Beaver Lake.

Fifteen dissolved solids, chloride, and sulfate fate and transport scenarios were compared to the baseline simulation at each of the seven downstream locations in the reservoir, both 2 meters $(\mathrm{m})$ below the surface and $2 \mathrm{~m}$ above the bottom. Concentrations were greater in the reservoir at model segments closer to where the tributaries entered the reservoir. Concentrations resulting from the increase in loading became more diluted farther downstream from the source. Differences in concentrations between the baseline condition and the $1.2,1.5$, and 2.0 times baseline concentration scenarios were smaller than the differences in the 5.0 and 10.0 times baseline concentration scenarios. The results for both the $2 \mathrm{~m}$ below the surface and $2 \mathrm{~m}$ above the bottom were similar, with the exception of concentrations resulting from the increased loading factors (5.0 and 10.0 times), where concentrations $2 \mathrm{~m}$ above the bottom were consistently greater than those $2 \mathrm{~m}$ below the surface at most segments.

\section{Introduction}

Beaver Lake is a large, deep-storage reservoir located in the upper White River Basin in northwestern Arkansas. The reservoir was completed in 1963 for the purposes of flood control, hydroelectric power, and water supply. In addition, the reservoir is used for fish and wildlife habitat, recreation, and waste assimilation.

Beaver Lake is affected by point and nonpoint sources of minerals, nutrients, and sediments. The City of Fayetteville discharges about half of its sewage effluent into the White River immediately upstream from the backwater of the reservoir. The City of West Fork discharges its sewage effluent into the West Fork of the White River, and the City of Huntsville discharges its sewage effluent into a tributary of War Eagle Creek. Water-quality constituents like dissolved solids (DS), chloride $(\mathrm{Cl})$, sulfate $\left(\mathrm{SO}_{4}\right)$, nutrients, sediment, pathogenic bacteria, and others enter Beaver Lake through its tributaries and around its shoreline and through precipitation on the pool.

In 2006, a study was conducted by Galloway and Green (2006) that analyzed ambient water-quality conditions. In Galloway and Green (2006), a two-dimensional model of hydrodynamics and water-quality characteristics was developed and calibrated for the period 2001 through 2003. For the present study, conducted by the U.S. Geological Survey (USGS) in cooperation with the City of Fayetteville and Beaver Water District (BWD), their model was modified and recalibrated to examine ambient conditions of DS, Cl, and $\mathrm{SO}_{4}$ and fate and transport of these compounds and elements in Beaver Lake from January 2006 through December 2010. 


\section{Purpose and Scope}

The purpose of this report is to describe the ambient conditions and fate and transport of $\mathrm{DS}, \mathrm{Cl}$, and $\mathrm{SO}_{4}$ concentrations in Beaver Lake. DS, $\mathrm{Cl}$, and $\mathrm{SO}_{4}$ are components of wastewater discharged into Beaver Lake and a major concern of the drinking water utilities that use Beaver Lake as their source. A previously developed CE-QUAL-W2 two-dimensional model of hydrodynamics and water quality in Beaver Lake (Galloway and Green, 2006) was modified and recalibrated to include simulations of $\mathrm{DS}, \mathrm{Cl}$, and $\mathrm{SO}_{4}$ for the period of January 2006 through December 2010. Estimated daily DS, $\mathrm{Cl}$, and $\mathrm{SO}_{4}$ loads were increased in the White River and War Eagle Creek tributaries, individually and the two tributaries together, by 1.2, 1.5, 2.0, 5.0, and 10.0 times the baseline conditions to examine fate and transport of these constituents through time at seven locations in the reservoir, from upstream to downstream in Beaver Lake.

\section{Description of Study Area}

Beaver Lake (fig. 1) was impounded in 1963 on the White River, is located northeast of the City of Fayetteville, Ark., and near Eureka Springs, Ark., and had reached conservation capacity in 1968 (Haggard and Green, 2002). The conservation capacity of the reservoir is the storage capacity used for hydroelectric power, water supply, fish and wildlife habitat, and recreation (U.S. Army Corps of Engineers, 1997). The main inflows into Beaver Lake are the White River, Richland Creek, and War Eagle Creek (fig. 1). Several smaller tributaries also flow into the reservoir. The reservoir has a drainage area of 3,087 square kilometers $\left(\mathrm{km}^{2}\right)$ at the Beaver Lake dam. Beaver Lake contains 2,040 million cubic meters $\left(\mathrm{m}^{3}\right)$ of water at the top of the current conservation pool (341.4 meters (m) above NGVD of 1929) and the surface area is $114 \mathrm{~km}^{2}$ (Haggard and Green, 2002). The length of the reservoir is 80 kilometers $(\mathrm{km})$ from the White River at the Highway 45 bridge to the Beaver Lake dam. The depth of the reservoir at the dam at conservation pool elevation is $60 \mathrm{~m}$, and the average depth throughout the reservoir is $18 \mathrm{~m}$ (Haggard and Green, 2002).

The USGS in cooperation with BWD has monitored water quality in Beaver Lake since 2001. Currently, waterquality samples are collected at seven lake sites (L1-L5, L9, and L10) and three tributary inflow sites (S1-S3) (table 1, fig. 1). Continuous streamflow data are also collected at S1, S2, and S3 and used to calculate constituent loading into Beaver Lake.

\section{Methods}

This section describes the methods of data collection and analysis used to describe the ambient $\mathrm{DS}, \mathrm{Cl}$, and $\mathrm{SO}_{4}$ conditions in Beaver Lake used in this report. Streamflow and water-quality samples were collected at three tributaries to Beaver Lake from January 2006 through December 2010. Annual DS, $\mathrm{Cl}$, and $\mathrm{SO}_{4}$ loads were estimated from streamflow and water-quality data at these three sites. Waterquality samples were also collected at seven fixed sites along the downstream gradient in the reservoir during the same time period.

\section{Streamflow}

Stream stage was measured continuously at White River near Fayetteville (site S1), Richland Creek at Goshen (site S2), and War Eagle Creek near Hindsville (site S3) (table 1 and fig. 1). Stage and instantaneous discharge were measured to compute the continuous streamflow from stage-discharge rating curves by using methods described by Rantz and others (1982). Outflow data from Beaver Lake were provided by the U.S. Army Corps of Engineers (USACE), Little Rock District, for the period January 2006 through December 2010.

\section{Water-Quality Sampling}

Water-quality data were collected from January 2006 through December 2010 at five fixed sites along the downstream gradient of Beaver Lake. Sample sites in the lake were located along the original stream channel, the deepest location within the lake cross section. Samples were collected six times annually at White River at Goshen (site L1), at Beaver Lake at Highway 412 bridge near Sonora (site L2), near Beaver Lake near Lowell (site L3), at Beaver Lake at Highway 12 bridge near Rogers (site L4), and Beaver Lake near Eureka Springs (site L5) (table 1 and fig.1). Samples were collected six times annually at War Eagle Creek above White River near Lowell (site L9) from October 2007 through December 2010 and monthly (12 times annually) at Beaver Lake downstream from Hickory Creek landing near Springdale (site L10) from August 2008 through December 2010.

Water-quality samples were collected at lake sites by using a peristaltic pump and weighted hose to collect samples $2 \mathrm{~m}$ below the water surface when isothermal and well-mixed conditions were present. During thermal stratification, samples were collected at $2 \mathrm{~m}$ below the water surface to represent the epilimnion (near surface), at various depths in the metalimnion (middle depth) depending on the depth of the thermocline, and at $2 \mathrm{~m}$ above the reservoir bottom to represent the hypolimnion (near bottom). Water-quality samples were analyzed for concentrations of DS (analytically determined by weighing residue after drying at 180 degrees Celsius $\left({ }^{\circ} \mathrm{C}\right)$, not the sum of individual constituents), $\mathrm{Cl}$, and $\mathrm{SO}_{4}$. All sample analyses were conducted at the USGS National Water Quality Laboratory according to USGS procedures (Fishman, 1993). Field measurements of water temperature were also recorded at various depths at the time of sample collection. 


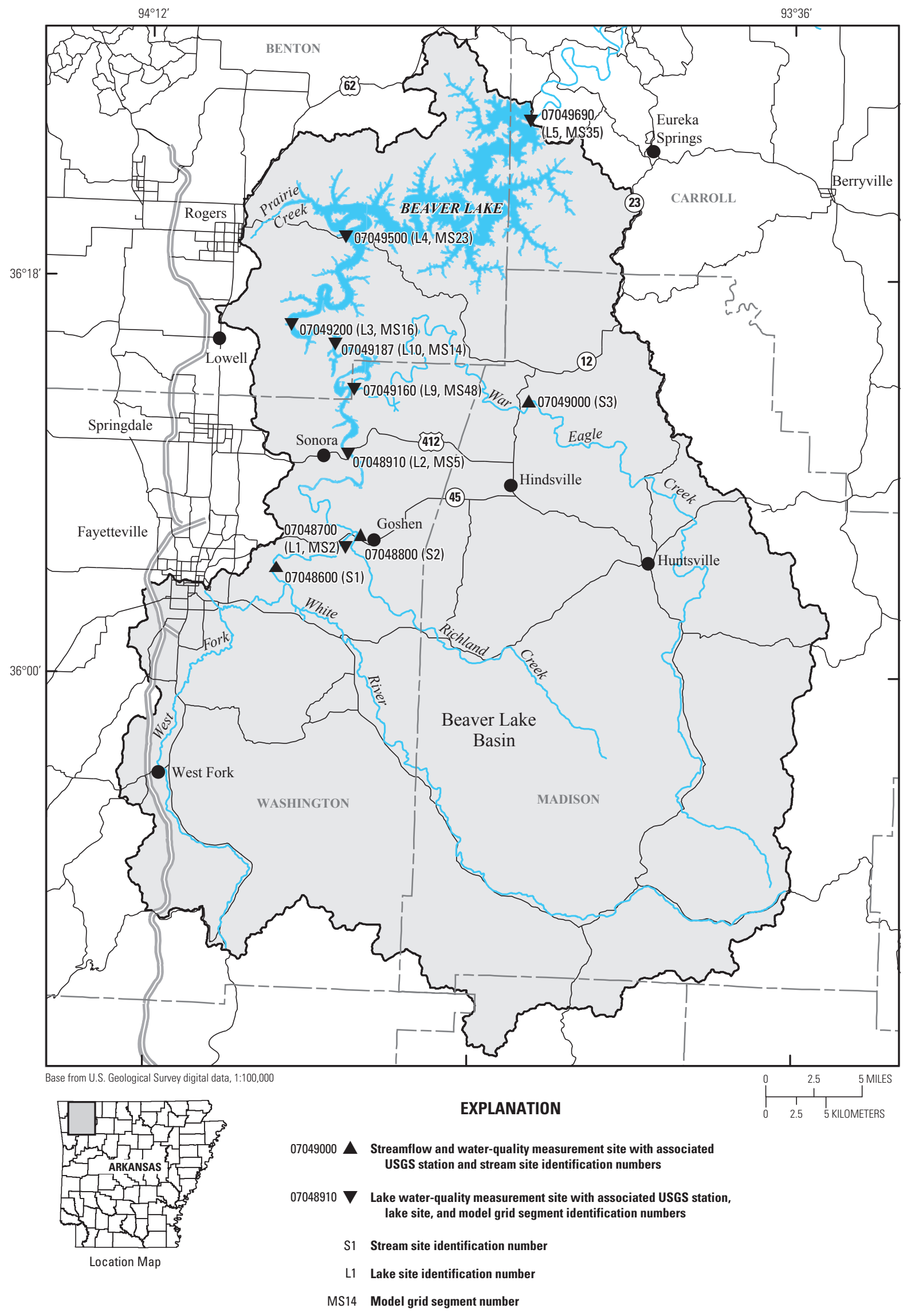

Figure 1. Beaver Lake study area, Arkansas, with locations of water-quality sampling sites. 
Table 1. Streamflow and water-quality sites for Beaver Lake, Arkansas

\begin{tabular}{|c|c|c|c|c|c|c|}
\hline $\begin{array}{c}\text { Site } \\
\text { identification } \\
\text { number (fig. 1) }\end{array}$ & $\begin{array}{c}\text { U.S. Geological } \\
\text { Survey station } \\
\text { number }\end{array}$ & $\begin{array}{l}\text { Model grid } \\
\text { segment } \\
\text { (fig. 2) }\end{array}$ & Station name & Station type & $\begin{array}{c}\text { Latitude } \\
\text { (degree,minute, } \\
\text { second) }\end{array}$ & $\begin{array}{c}\text { Longitude } \\
\text { (degree, minute, } \\
\text { second) }\end{array}$ \\
\hline $\mathrm{S} 1$ & 07048600 & - & White River near Fayetteville & $\begin{array}{l}\text { Streamflow, } \\
\text { water quality }\end{array}$ & $36^{\circ} 04^{\prime} 23^{\prime \prime}$ & $94^{\circ} 04^{\prime} 52^{\prime \prime}$ \\
\hline $\mathrm{S} 2$ & 07048800 & - & Richland Creek at Goshen & $\begin{array}{l}\text { Streamflow, } \\
\text { water quality }\end{array}$ & $36^{\circ} 06^{\prime} 15^{\prime \prime}$ & $94^{\circ} 00^{\prime} 28^{\prime \prime}$ \\
\hline S3 & 07049000 & - & $\begin{array}{l}\text { War Eagle Creek } \\
\text { near Hindsville }\end{array}$ & $\begin{array}{l}\text { Streamflow, } \\
\text { water quality }\end{array}$ & $36^{\circ} 12^{\prime} 00^{\prime \prime}$ & $93^{\circ} 51^{\prime} 18^{\prime \prime}$ \\
\hline L1 & 07048700 & 2 & White River near Goshen & Water quality & $36^{\circ} 06^{\prime} 21^{\prime \prime}$ & $94^{\circ} 00^{\prime} 41^{\prime \prime}$ \\
\hline L2 & 07048910 & 5 & $\begin{array}{l}\text { Beaver Lake at Highway } 412 \\
\text { bridge near Sonora }\end{array}$ & Water quality & $36^{\circ} 10^{\prime} 00^{\prime \prime}$ & $94^{\circ} 00^{\prime} 26^{\prime \prime}$ \\
\hline L3 & 07049200 & 16 & Beaver Lake near Lowell & Water quality & $36^{\circ} 15^{\prime} 33^{\prime \prime}$ & $94^{\circ} 04^{\prime} 08^{\prime \prime}$ \\
\hline L4 & 07049500 & 23 & $\begin{array}{l}\text { Beaver Lake at Highway } 12 \\
\text { bridge near Rogers }\end{array}$ & Water quality & $36^{\circ} 19^{\prime} 56^{\prime \prime}$ & $94^{\circ} 01^{\prime} 08^{\prime \prime}$ \\
\hline L5 & 07049690 & 35 & $\begin{array}{l}\text { Beaver Lake near Eureka } \\
\text { Springs }\end{array}$ & Water quality & $36^{\circ} 25^{\prime} 15^{\prime \prime}$ & $93^{\circ} 50^{\prime} 50^{\prime \prime}$ \\
\hline L9 & 07049160 & 48 & $\begin{array}{l}\text { War Eagle Creek above White } \\
\text { River near Lowell }\end{array}$ & Water quality & $36^{\circ} 13^{\prime} 24^{\prime \prime}$ & $94^{\circ} 00^{\prime} 38^{\prime \prime}$ \\
\hline L10 & 07049187 & 14 & $\begin{array}{l}\text { Beaver Lake downstream } \\
\text { from Hickory Creek } \\
\text { landing near Springdale }\end{array}$ & Water quality & $36^{\circ} 15^{\prime} 01^{\prime \prime}$ & $94^{\circ} 01^{\prime} 35^{\prime \prime}$ \\
\hline
\end{tabular}

Water-quality samples also were collected from three fixed inflow sites: White River near Fayetteville (site S1), Richland Creek at Goshen (site S2), and War Eagle Creek near Hindsville (site S3) (table 1, fig. 1). Water-quality samples were collected following equal-width increment methods by using depth-integrated samplers and processed by using protocols described in Wilde and Radke (1998) and Wilde and others (1998a, 1998b, 1998c, 1999a, and 1999b). Water-quality samples were analyzed for concentrations of DS, $\mathrm{Cl}$, and $\mathrm{SO}_{4}$. Field measurements including water temperature were collected with each sample. Water-quality samples were collected six times annually and during selected surface-runoff events.

\section{Constituent Loads}

DS, $\mathrm{Cl}$, and $\mathrm{SO}_{4}$ loads were estimated for the three main inflows to Beaver Lake: the White River near Fayetteville (site S1), Richland Creek at Goshen (site S2), and War Eagle Creek near Hindsville (site S3) (fig. 1). Constituent load $(L)$ is a function of the volumetric rate of water passing a point in the stream $(Q)$ and the constituent concentration within the water (C). Regression methods used to estimate constituent loads use the natural logarithm $(\ln )$ transformed relation between $Q$ and $C$ to estimate daily load $(L)$ of the constituent. The regression method can account for nonnormal data distributions, seasonal and long-term cycles, censored data, biases associated with using logarithmic transformations, and serial correlations of the residuals (Cohn, 1995). The regression method uses discrete water-quality samples often collected over several years and a daily streamflow hydrograph. The relations between natural logarithmic-transformed $L(\mathrm{QC})$ and $Q$ were used:

$$
\ln (L)=\beta_{0}+\beta_{1} \ln (Q)
$$

where

$$
\begin{array}{cl}
\text { In } & \text { is natural logarithm; } \\
L & \text { is constituent load, in kilograms per day } \\
& (\mathrm{kg} / \mathrm{d}) ; \\
\beta_{\mathrm{o}} & \text { is regression constant, dimensionless; } \\
\beta_{1} & \text { is a regression coefficient, dimensionless; and } \\
Q & \text { is daily streamflow, in cubic meters per } \\
& \text { second }\left(\mathrm{m}^{3} / \mathrm{s}\right) .
\end{array}
$$

Transformation of the results of the model from logarithmic space to real space was accomplished by using two methods: an adjusted maximum likelihood estimator (AMLE) and a least absolute deviation (LAD) (Cohn and others, 1992). The AMLE method was used if the constituent had censored values, and the LAD method was used to transform the results if no censored values were included in the data or if outliers in the residuals were present. The S-LOADEST computer program (Runkel and others, 2004) was used to estimate daily loads for 2006 through 2010. 


\section{Data Analysis}

The resulting measured streamflow, water-quality (DS, $\mathrm{Cl}$, and $\mathrm{SO}_{4}$ concentrations - inflow and lake samples), and S-LOADEST loading rates were analyzed and summarized by using several graphical techniques for data collected from January 2006 through December 2010. Time-series plots were used to describe inflow and outflow. Boxplots and time-series plots were used to compare concentrations of DS, $\mathrm{Cl}$, and $\mathrm{SO}_{4}$ among sites. Boxplots, scatter plots, line plots, and bar charts were used to describe model simulation results.

\section{Model Implementation}

A two-dimensional, laterally averaged, hydrodynamic and water-quality model using CE-QUAL-W2 Version 3.1 (Cole and Wells, 2003) had been developed for Beaver Lake and calibrated on the basis of vertical profiles of temperature and dissolved oxygen, and water-quality constituent concentrations were collected at various depths at four sites in the reservoir from April 2001 to April 2003 (Galloway and Green, 2006). This Beaver Lake CE-QUAL-W2 model had simulated water-surface elevation and vertical and longitudinal gradients in water-quality constituents. The model had included routines for 18 state variables in addition to temperature and dissolved oxygen, including any number of inorganic suspended solids groups, phytoplankton groups, nitrogen and phosphorus species, dissolved and particulate organic matter, total inorganic carbon, and organic sediment. Additionally, CE-QUAL-W2 had the capability of computing more than 60 derived variables from the state variables (Cole and Wells, 2003); however, for the purposes of this report, only water temperature, $\mathrm{DS}, \mathrm{Cl}$, and $\mathrm{SO}_{4}$ were simulated. DS, $\mathrm{Cl}$, and $\mathrm{SO}_{4}$ were considered to be conservative constituents and changed concentration only through advection and dilution, as a conservative tracer might be expected to behave.

Implementation of the CE-QUAL-W2 model for Beaver Lake included development of the computational grid, specification of boundary and initial conditions, and preliminary selection of model parameter values. Model development and associated assumptions in the selection of boundary and initial conditions are described and model parameters are listed in the "Boundary and Initial Conditions" and "Model Parameters" sections.

\section{Computational Grid}

The computational grid used by Galloway and Green (2006) and used in this study provides the geometric scheme that numerically represents the space and volume of Beaver Lake. The grid extends $80 \mathrm{~km}$ from the upstream boundary (White River at the Highway 45 bridge) to the Beaver Lake dam (figs. 1 and 2). The grid originally was developed by Haggard and Green (2002) to simulate the hydrodynamics and distribution of temperature and dissolved oxygen in
Beaver Lake for calendar years 1994 and 1995. Thirty-five computational segments exist along the main stem branch of the White River and 12 computational segments are in War Eagle Creek branch in Beaver Lake. In addition, four other downstream branches are modeled with three computational segments each. Volumes of the smaller embayments not included in the computational grid were added to associated main stem segments so that reservoir volume was preserved. Each segment was divided vertically into 1-m layers. Tributaries were linked geometrically to the segment they enter and allow for the application of inflow without affecting the geometry. Two tributaries were included in the model at the most upstream segment. One tributary was used to simulate the discharge from the Fayetteville wastewatertreatment plant (WWTP) at the upstream segment although WWTP discharge concentrations were not included for the purposes of this study; $\mathrm{DS}, \mathrm{Cl}$ and $\mathrm{SO}_{4}$ concentration data in WWTP discharge were limited and uncertain. A second tributary was used to simulate the inflow from Richland Creek, and a third to simulate the inflow from Prairie Creek (fig. 1). Model grid segments 2, 5, 14, 16, 23, 35, and 48 (fig. 2) relate to water-quality monitoring sites L1, L2, L10, L3, L4, L5, and L9, respectively (table 1).

\section{Boundary and Initial Conditions}

\section{Hydraulic and Thermal Boundary Conditions}

Daily reservoir inflow data (upstream hydraulic boundaries) used in the model were obtained from streamflowgaging station data on the three main inflows (White River, Richland Creek, and War Eagle Creek) and were estimated for the three smaller ungaged branches and the tributary, Prairie Creek. The mean daily streamflow recorded for War Eagle Creek near Hindsville (site S3, upstream from L9) was used to estimate the streamflow for the three ungaged branches and tributary, based on the ratio between the drainage area for War Eagle Creek at site S3 and the drainage areas of the three ungaged branches and tributary.

The downstream hydraulic boundary for the Beaver Lake model consisted of the outflow from Beaver Lake dam. The USACE produced hourly outflow data by using stagedischarge relations and hourly power generation records for the period of January 2006 through December 2010 (U.S. Army Corps of Engineers, written commun., 2011). The release structure (penstock) was simulated as a point release, and the middle of the penstock was located at an elevation of 302.2 m above NGVD of 1929, model layer 45 (fig. 2).

Hydraulic boundary conditions also included water withdrawal by four public water-supply districts (Beaver Water District, Carroll-Boone County Water District, Madison County Water District, and Benton-Washington County Water District). Annualized mean daily withdrawal rates for each water-supply district were applied (Terrance W. Holland, U.S. Geological Survey, written commun., 2011). 


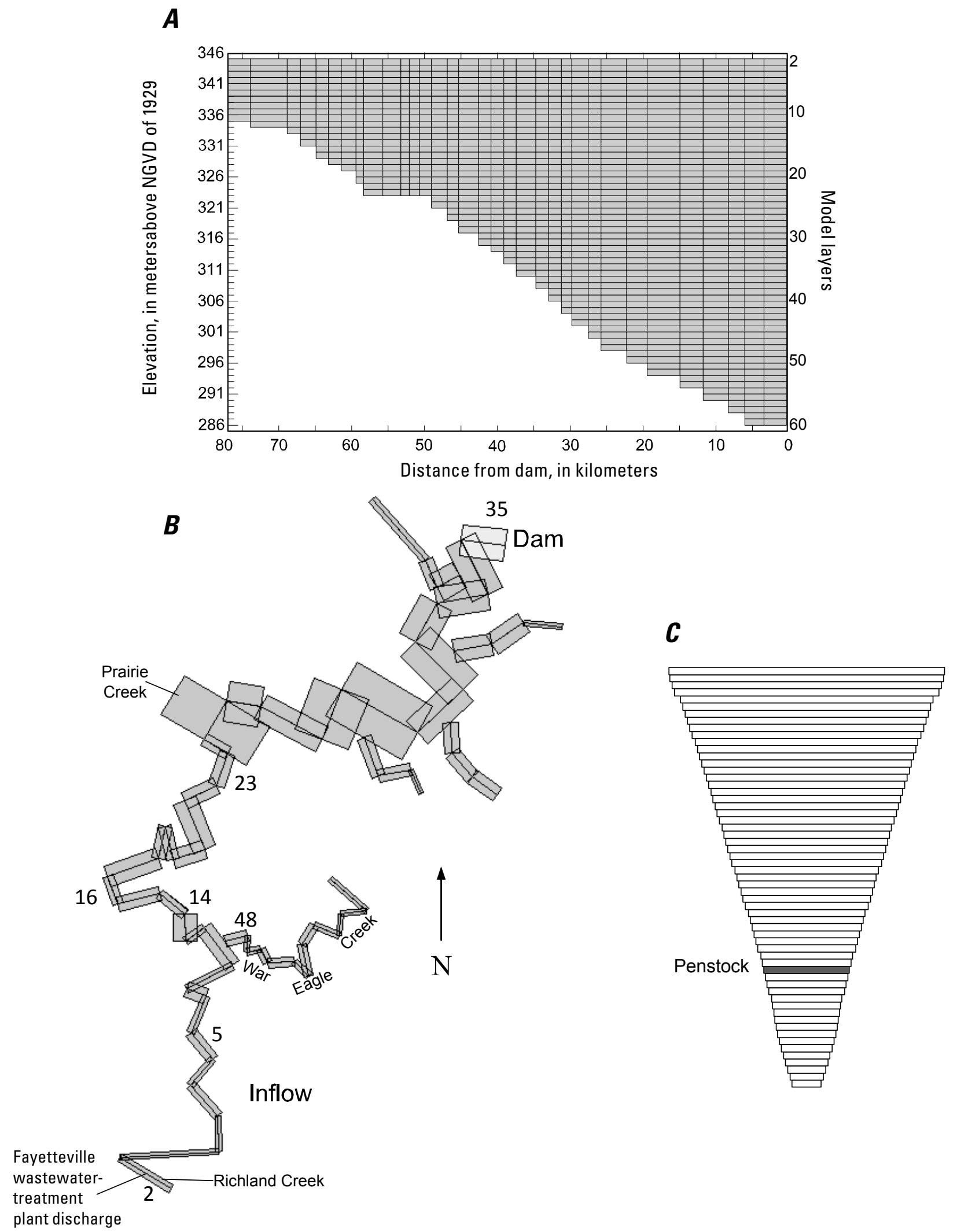

Figure 2. Side view $(A)$, top view $(B)$, and face view from the dam $(C)$ of the computational grid of Beaver Lake, Arkansas, used in the CE-QUAL-W2 model. 
Hydraulic boundary conditions at the water surface included evaporation, wind stress, and surface heat exchange. Meteorological data required for these computations were measured hourly at a weather station southwest of Rogers (fig. 1) (National Climatic Data Center, Asheville, North Carolina, written commun., 2011).

Hourly inflow water temperatures were estimated from air temperature in the meteorological data by using the Marciano and Harbeck (1954) method and from periodic measurements at the three main inflow sites (White River, Richland Creek, and War Eagle Creek). Water temperatures for the three smaller branches and Prairie Creek were estimated only from air temperature.

\section{Dissolved Solids, Chloride, and Sulfate Boundary Conditions}

Chemical boundary conditions were estimated daily, by dividing daily S-LOADEST loads ( $\mathrm{kg} / \mathrm{d})$ by the daily mean streamflow $\left(\mathrm{m}^{3} / \mathrm{s}\right)$ to provide a daily mean concentration $(\mathrm{mg} / \mathrm{L})$ for each of the main inflow sites. Daily mean streamflow was used to calculate daily mean concentrations from daily S-LOADEST loads because it probably more accurately reflected the variation in constituent concentrations compared to using discrete concentrations as input, where the model linearly interpolates daily concentrations between sample collection dates.

\section{Initial Conditions}

Initial water-surface elevation, water temperature, and $\mathrm{DS}, \mathrm{Cl}$, and $\mathrm{SO}_{4}$ concentrations for each model segment are required at the start of a model simulation. Initial watersurface elevations were set to the measured value (337.0 $m$ above NGVD of 1929) on January 1, 2006. At this time, Beaver Lake was assumed to be in isothermal conditions throughout the entire reservoir with an initial water temperature of $6{ }^{\circ} \mathrm{C}$. Initial DS, $\mathrm{Cl}$, and $\mathrm{SO}_{4}$ concentrations also were assumed to be uniform and were set at 80, 4.0, and $9.0 \mathrm{mg} / \mathrm{L}$, respectively.

\section{Model Parameters}

Parameters are used to describe the physical and chemical processes that are not explicitly modeled and to provide the chemical kinetic rate information. Many parameters cannot be measured directly and often are adjusted during the model calibration process until simulated values, for example, water temperature, dissolved oxygen, and others, agree with measured observations. Most of the hydrodynamic and thermal processes are modeled in CE-QUAL-W2, which results in very few adjustable hydraulic and thermal parameters. There are many chemical and biological rate coefficients required for the application of CE-QUAL-W2, which were all temporally constant (table 2). Many of the coefficients were based on suggested values given as default values for CE-QUAL-W2, and others were based on other model applications (Bales and others, 2001; Haggard and Green, 2002; Galloway and Green, 2002 and 2003; Green and others, 2003; Sullivan and Rounds, 2005).

\section{Model Calibration and Testing}

Successful model application requires model calibration that includes comparing simulated results with measured reservoir conditions. The Beaver Lake model calibration was completed by adjusting parameters for the 5-year period from January 2006 through December 2010. Calibration was achieved generally by calibrating the water balance first and then the thermodynamics.

Two statistics were used to compare simulated and measured water temperature and $\mathrm{DS}, \mathrm{Cl}$, and $\mathrm{SO}_{4}$ concentrations. The absolute mean error (AME) indicated the average difference between simulated and measured values and was computed by equation 2 :

$$
A M E=\frac{\sum \mid \text { simulated value }- \text { measured value } \mid}{\text { number of observations }}
$$

Table 2. Parameters and values used in the CE-QUAL-W2 model of Beaver Lake, January 2006 to December 2010.

\begin{tabular}{lcl}
\hline \multicolumn{1}{c}{ Parameter description } & Values & \multicolumn{1}{c}{ Units } \\
\hline Coefficient of bottom heat exchange & 0.3 & watts/square meter/ second \\
Sediment temperature & 20.0 & degrees Celsius \\
Wind-sheltering coefficient & 0.7 & dimensionless \\
Horizontal eddy viscosity & 1.0 & square meters /second \\
Horizontal eddy diffusivity & 1.0 & square meters/second \\
Light extinction coefficient for pure water & 0.35 & $1 /$ meter \\
Fraction of incident solar radiation absorbed at water surface & 0.32 & dimensionless \\
\hline
\end{tabular}


An AME of $1.5^{\circ} \mathrm{C}$, for example, means that the average difference between simulated temperatures and measured temperature is $1.5^{\circ} \mathrm{C}$.

The root mean square error (RMSE) indicated the spread of how far simulated values deviated from the measured values and was computed by equation 3 :

$$
R M S E=\sqrt{\frac{\sum(\text { simulated value }- \text { measured value })^{2}}{\text { number of observations }}}
$$

An RMSE of $1.5^{\circ} \mathrm{C}$, for example, means that the simulated temperatures are within $1.5^{\circ} \mathrm{C}$ of the measured temperatures about 67 percent of the time.

\section{Water Balance}

Simulated water-surface elevations in Beaver Lake were adjusted to the measured water-surface elevation near the dam for the model period of January 2006 through December 2010 (fig. 3). The simulated water-surface elevations were corrected to the measured values by adjusting the unmeasured inflow into the lake that had been distributed to all the segments within a branch. Inflow was added or subtracted so that the simulated water-surface elevation reflected the measured water-surface elevation, therefore accounting for unmeasured inflow and groundwater interaction in Beaver Lake. By correcting the distributed inflow, the temperature and water quality could be calibrated without the uncertainty incurred with having differences between simulated and measured water-surface elevations.

\section{Sensitivity Analysis}

A sensitivity analysis is the determination of the effects of small changes in the calibrated model parameters and input on model results. A complete sensitivity analysis for the Beaver Lake model was not conducted. Testing of how changes in different parameters affect the hydrodynamics, temperature, and water quality, however, was conducted as part of the model development and calibration. Results from the model development and calibration runs plus information from previous model studies (Bales and others, 2001;

Haggard and Green, 2002; Galloway and Green, 2002, 2003; Green and others, 2003; Sullivan and Rounds, 2005) were used to identify several parameters for partial evaluation in the sensitivity analysis.

The sensitivity of simulated water temperature and water quality was assessed with changes in the windsheltering coefficient and light-extinction coefficient (for pure water). Simulated vertical profiles of water temperature, at 1-m depth intervals, were compared with measured water-temperature profiles.

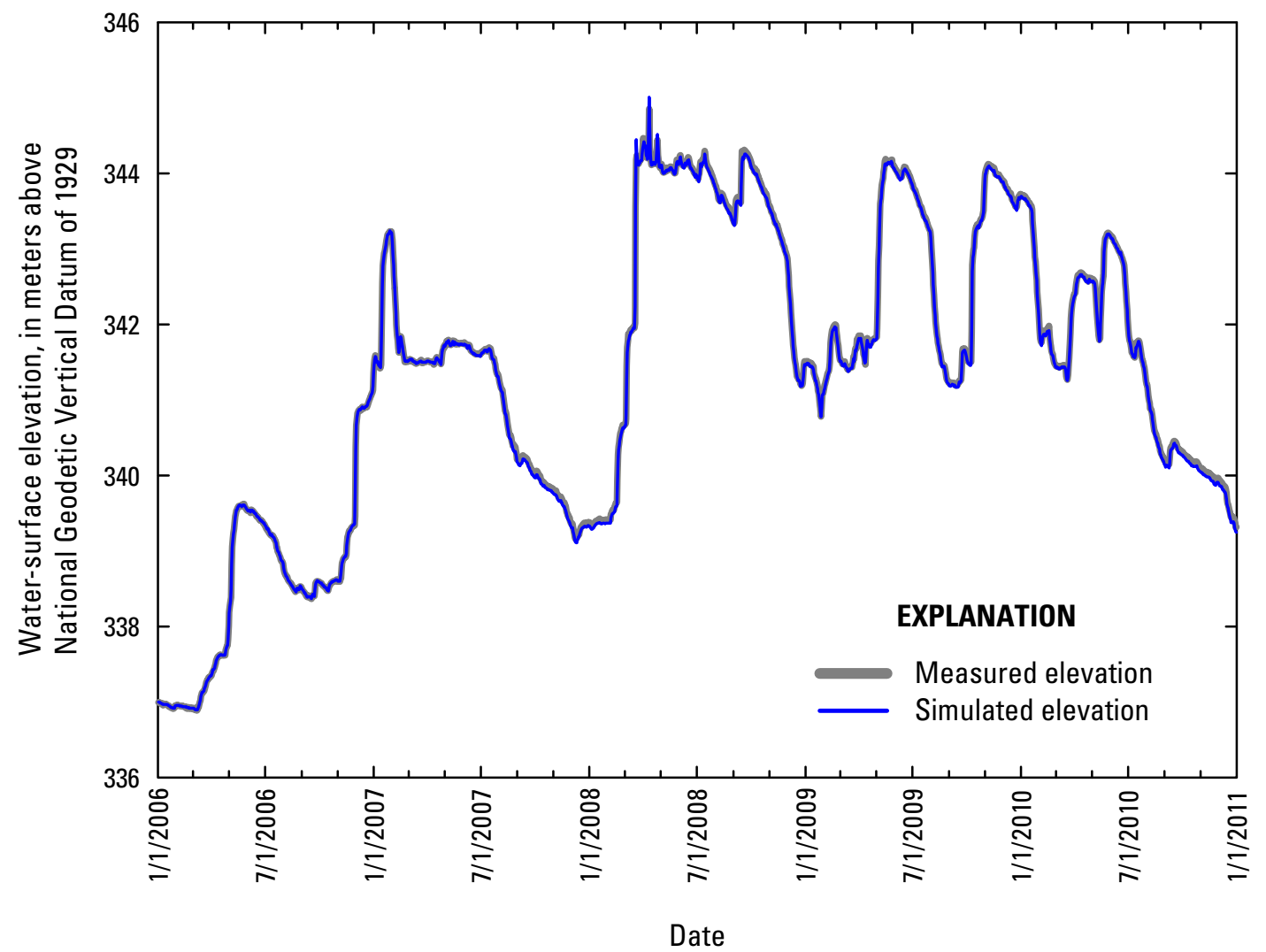

Figure 3. Simulated and measured water-surface elevations near Beaver Lake dam, Arkansas, January 2006 through December 2010. 
Water temperature in the Beaver Lake model was the most sensitive to wind speed (wind-sheltering coefficient, table 2). The wind speed, adjusted by using the windsheltering coefficient, affects the amount of mixing in the reservoir, which can change the depth of the thermocline and increase or decrease the evaporative cooling.

Sensitivity analysis of DS, $\mathrm{Cl}$, and $\mathrm{SO}_{4}$ was not conducted. These water-quality constituents were considered conservative and only changed concentration through advection and dilution, as a conservative tracer might be expected to behave.

\section{Model Limitations}

The accuracy of the Beaver Lake model was limited by the simplification of the complexities of the hydrodynamics within the reservoir, by spatial and temporal discretization effects, and by assumptions made in the formulation of the governing equations. Model accuracy also was limited by segment size, boundary conditions, accuracy of calibration, and parameter sensitivity. Moreover, model accuracy was limited by the availability of data and by the interpolations and extrapolations that were inherent in using data in a model. Although a model might be calibrated, calibration parameter values are generally not necessarily unique in yielding acceptable values for the selected water-quality constituents and reservoir water-surface elevation.

Another limitation of the Beaver Lake model was that it is a two-dimensional representation of a three-dimensional water body. The governing equations are laterally and vertically averaged within layers. Although the model may have accurately represented vertical and longitudinal processes within the reservoir, processes that occur laterally, or from shoreline to shoreline perpendicular to the downstream axis, may not have been properly represented.

\section{Ambient Conditions of Dissolved Solids, Chloride, and Sulfate in Beaver Lake}

This section describes the ambient hydrologic and waterquality conditions for Beaver Lake from January 2006 through December 2010. Streamflow in the three major tributaries, outflow at Beaver Lake dam, and pool elevation for Beaver Lake are described for the period. In addition, water-quality conditions for the three major tributaries and for seven sites on Beaver Lake are described for January 2006 through December 2010. These data were retrieved and are still available from the USGS National Water Quality Information System Web site: http://waterdata.usgs.gov/ar/nwis/qw/.

\section{Hydrologic Conditions}

Streamflow varied substantially from January 2006 through December 2010 for the three major tributaries that provide inflow to Beaver Lake (fig. 4). The White River is the main inflow into Beaver Lake, and approximately 34 percent of the drainage area at Beaver Lake dam is above the streamflow-gaging station near Fayetteville (site S1, fig. 1). The daily mean streamflow for the White River ranged from 0.01 to $1,215 \mathrm{~m}^{3} / \mathrm{s}$ for the period of January 2006 through December 2010. Mean daily streamflow for the period was $16.3 \mathrm{~m}^{3} / \mathrm{s}$. The drainage area of Richland Creek above the gaging station at Goshen (site S2, fig. 1) composes 12 percent of the drainage area at Beaver Lake dam. The daily mean streamflow for Richland Creek ranged from 0.003 to $957 \mathrm{~m}^{3} / \mathrm{s}$ for the period of January 2006 through December 2010, with a mean daily streamflow of $6.06 \mathrm{~m}^{3} / \mathrm{s}$ for the period. War Eagle Creek at the gaging station near Hindsville (site S3, fig. 1) has a drainage area that composes 22 percent of the drainage area at Beaver Lake dam. The daily mean streamflow for War Eagle Creek ranged from 0.312 to $767 \mathrm{~m}^{3} / \mathrm{s}$ for the period of January 2006 through December 2010, with a mean daily streamflow of $9.90 \mathrm{~m}^{3} / \mathrm{s}$ for the period.

The outflow from Beaver Lake also varied substantially for the period of January 2006 through December 2010 (fig. 4). Outflow discharge at Beaver Lake dam ranged from 1.76 $\mathrm{m}^{3} / \mathrm{s}$ to $2,254 \mathrm{~m}^{3} / \mathrm{s}$, with a mean outflow discharge of $35.3 \mathrm{~m}^{3} / \mathrm{s}$ for the period. Four public water-supply withdrawals also are located on Beaver Lake near the dam.

The water-surface elevation for Beaver Lake varied according to changes in the inflow and outflow for the reservoir (fig. 3). Water-surface elevation started off low in January 2006 reaching a minimum elevation March 7, 2006, at $336.9 \mathrm{~m}$ above NGVD of 1929 and remained below the top of conservation pool (341.4 m above NGVD of 1929) for most of 2006. Water-surface elevation reached a maximum elevation of 344.9 m above NGVD of 1929 on April 11, 2008.

\section{Water-Quality Conditions}

Water quality has been monitored in Beaver Lake by the USGS in cooperation with Beaver Water District since 2001. Water-quality samples are collected from both highflow events and base flow to characterize conditions within the entire hydrograph. Samples are collected in the reservoir at sites positioned along the downstream gradient. Vertical samples are collected within the water column when the lake is thermally stratified in the epilimnion, metalimnion, and hypolimnion. When the lake is not thermally stratified, only one sample (epilimnion) is collected. Both inflow and reservoir samples are analyzed for a number of constituents, $\mathrm{DS}, \mathrm{Cl}$, and $\mathrm{SO}_{4}$, included. 

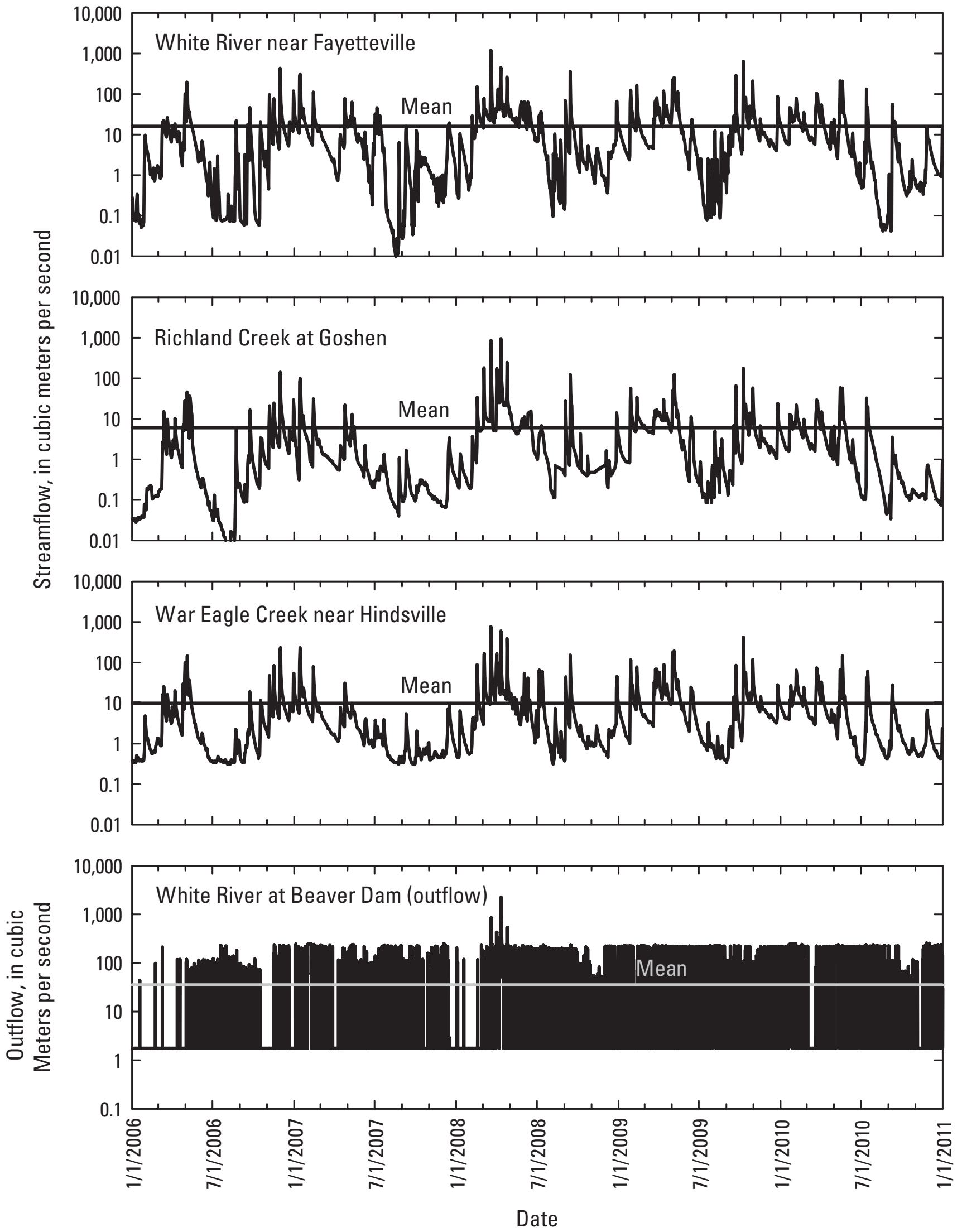

Figure 4. Mean daily streamflow for White River (site S1), Richland Creek (site S2), and War Eagle Creek (site S3), and hourly outflow at Beaver Lake dam. 


\section{Inflow Water Quality}

Water-quality samples were collected at the three main inflows to Beaver Lake: the White River near Fayetteville (site S1), Richland Creek at Goshen (site S2), and War Eagle Creek near Hindsville (site S3) (fig. 1). Measured DS, Cl, and $\mathrm{SO}_{4}$ concentrations varied among the tributaries because of differences in land use and contributions from point sources. DS concentrations were greater at Richland Creek and War Eagle Creek than White River (fig. 5). The median DS concentrations at White River, Richland Creek, and War Eagle Creek were 72, 96, and $109 \mathrm{mg} / \mathrm{L}$, respectively. $\mathrm{Cl}$ concentrations were greater at War Eagle Creek than Richland Creek and White River (fig. 5). The median Cl concentrations at White River, Richland Creek, and War Eagle Creek were 3.1, 4.1, and $6.9 \mathrm{mg} / \mathrm{L}$, respectively. The median $\mathrm{SO}_{4}$ concentration was greater at White River and Richland Creek than War Eagle Creek (fig. 5). The median $\mathrm{SO}_{4}$ concentrations at White River, Richland Creek, and War Eagle Creek were 10.6, 9.5, and $5.8 \mathrm{mg} / \mathrm{L}$, respectively.

The inflow of $\mathrm{DS}, \mathrm{Cl}$, and $\mathrm{SO}_{4}$ input from groundwater into Beaver Lake was not considered in this study. Groundwater inflow through the bottom of the reservoir was not considered a boundary condition in the model and therefore not simulated. Tributary base flow into Beaver Lake was considered to be dominated by groundwater; therefore, groundwater inflow was indirectly accounted for in tributary loading.

\section{Reservoir Water Quality}

Water-quality samples were collected at the seven sites in Beaver Lake: White River near Goshen (site L1), Beaver Lake at Highway 412 bridge near Sonora (site L2),
Beaver Lake near Lowell (site L3), Beaver Lake at Highway 12 bridge near Rogers (site L4), Beaver Lake near Eureka Springs (site L5), War Eagle Creek above White River near Lowell (site L9), and Beaver Lake downstream from Hickory Creek landing near Springdale (site L10) (table 1, fig. 1). Concentrations of $\mathrm{DS}, \mathrm{Cl}$, and $\mathrm{SO}_{4}$ were analyzed from samples collected $1 \mathrm{~m}$ below the surface at White River near Goshen (site L1) and $1 \mathrm{~m}$ above the bottom, when the water column was thermally stratified. When the water column was isothermal, one sample was collected $1 \mathrm{~m}$ below the surface. Samples were collected $2 \mathrm{~m}$ below the surface and $2 \mathrm{~m}$ above the reservoir bottom at the other six sampling sites. When the water column was isothermal, one sample was collected $2 \mathrm{~m}$ below the surface.

Measured DS, $\mathrm{Cl}$, and $\mathrm{SO}_{4}$ concentrations varied among lake sites relative to their downstream distance from the tributary point of entry to Beaver Lake (fig. 6). DS, $\mathrm{Cl}$, and $\mathrm{SO}_{4}$ concentrations were most variable at the upper end of the reservoir, White River near Goshen (site L1). The City of Fayetteville discharges wastewater into the White River, upstream from site L1 near Goshen and downstream from White River near Fayetteville (site S1). Although the variability in DS concentrations was greatest at White River near Goshen (site L1), the greatest median value $(98 \mathrm{mg} / \mathrm{L})$ occurred at War Eagle Creek above White River near Lowell (site L9), followed by Beaver Lake at Highway 412 bridge near Sonora (site L2, $93 \mathrm{mg} / \mathrm{L}$ ) and Beaver Lake downstream from Hickory Creek landing near Springdale (site L10, 91 $\mathrm{mg} / \mathrm{L}$ ). Variability and median concentrations for both $\mathrm{Cl}$ $(5.4 \mathrm{mg} / \mathrm{L})$ and $\mathrm{SO}_{4}(13.0 \mathrm{mg} / \mathrm{L})$ were greatest at White River near Goshen (site L1) and generally decreased the farther downstream the site was located. 

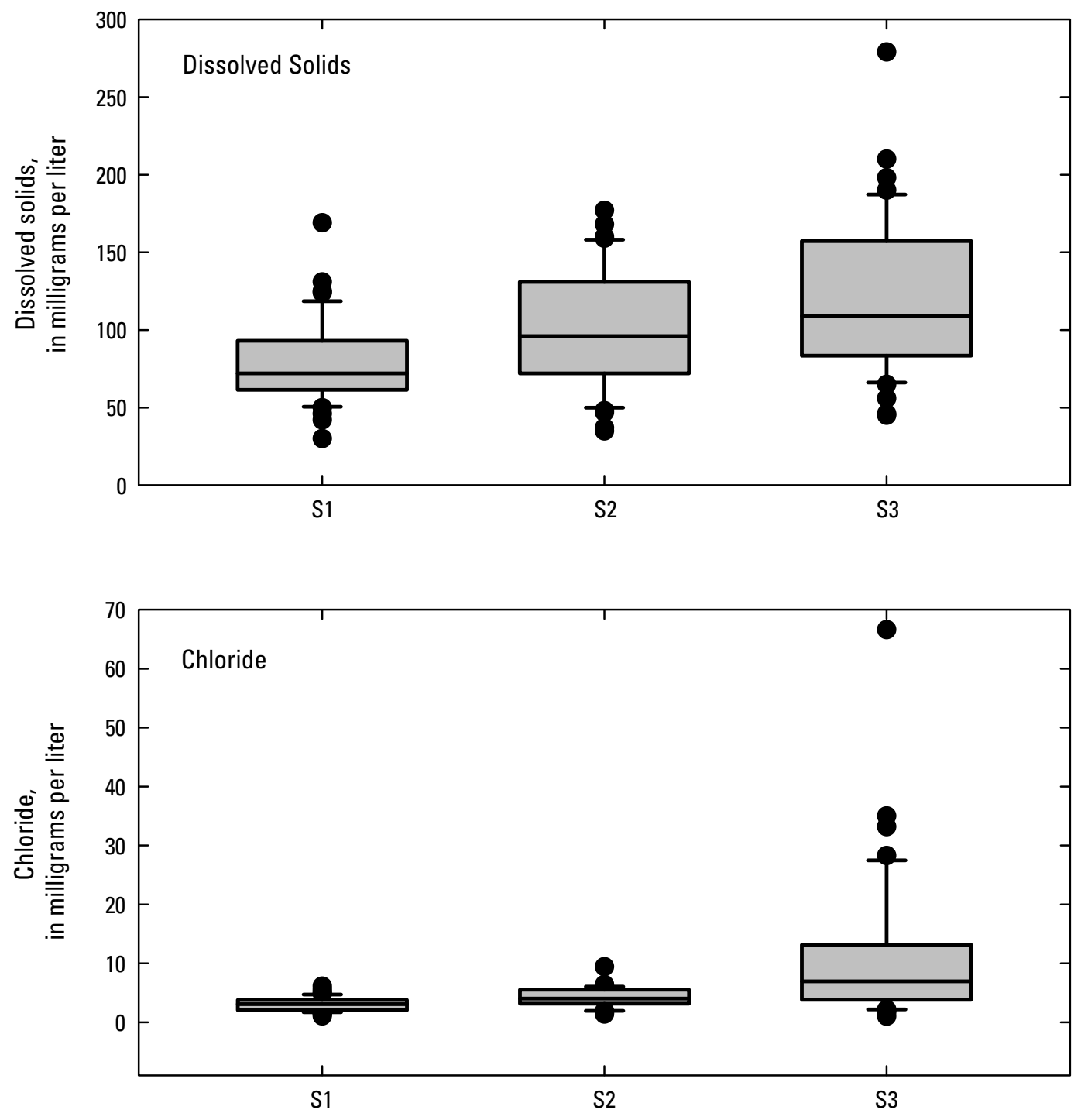

\section{EXPLANATION}

- Outlier

T 90th percentile

75 th percentile

50th percentile

25th percentile

$\perp$ 10th percentile

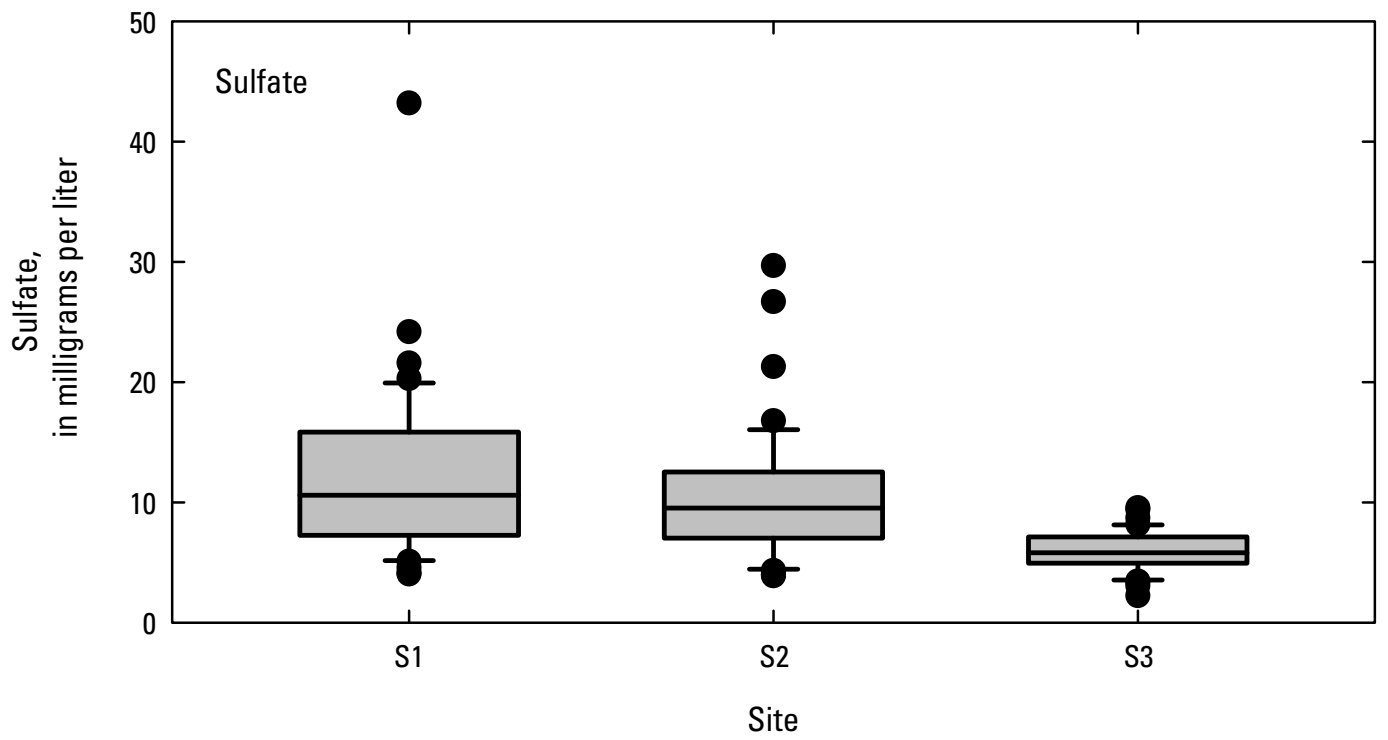

Figure 5. Distribution of dissolved solids, chloride, and sulfate concentrations for White River (site S1), Richland Creek (site S2), and War Eagle Creek (site S3), 2006-10. 

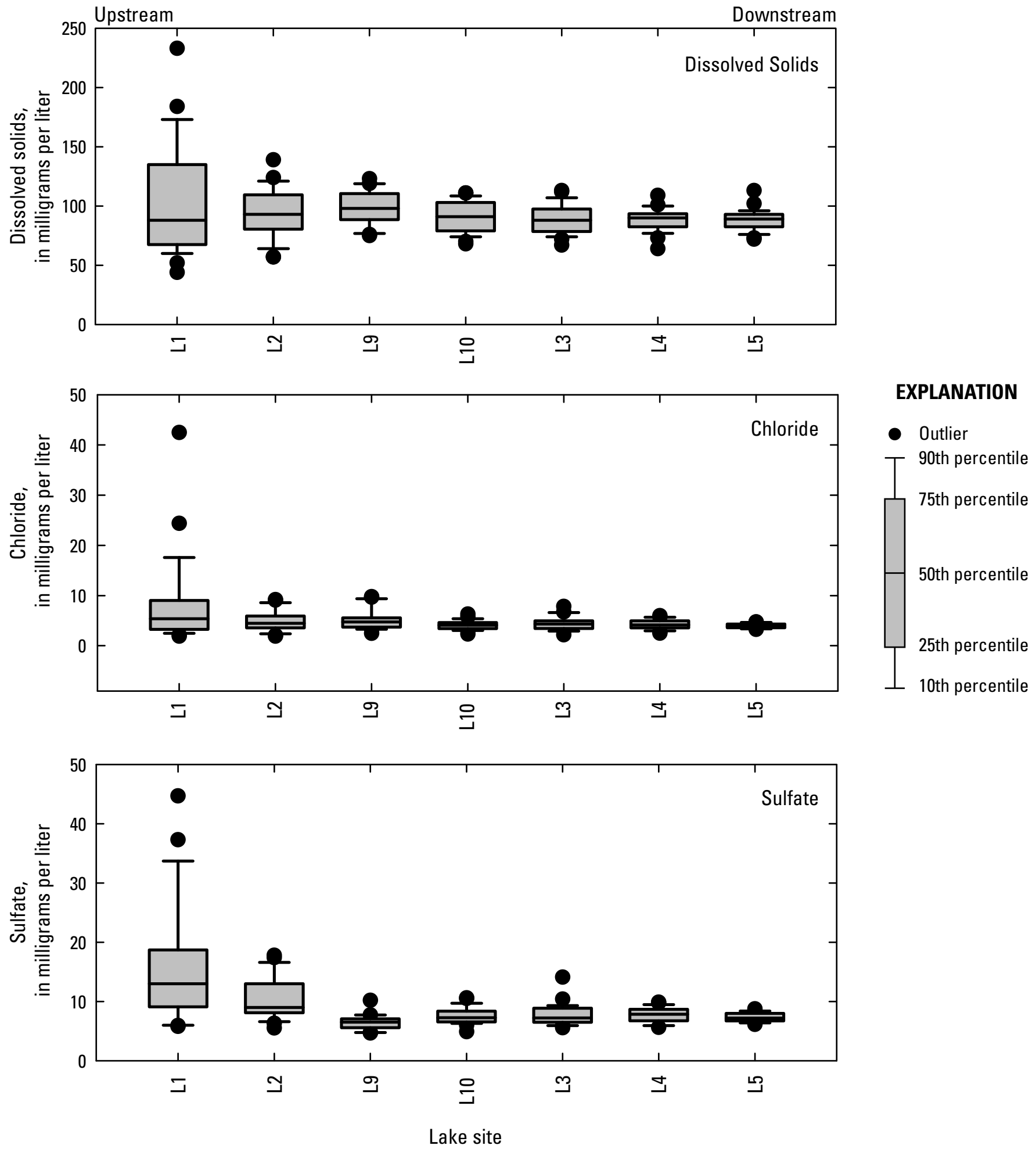

Figure 6. Distribution of dissolved solids, chloride, and sulfate concentrations 2 meters (m) below the surface at lake sites L1-L5, L9, and L10, 2006-10. 


\section{Dissolved Solids, Chloride, and Sulfate Fate and Transport Simulations}

\section{Inflow Loads and Concentrations}

Estimated daily DS, $\mathrm{Cl}$, and $\mathrm{SO}_{4}$ concentrations in the Beaver Lake model were determined by dividing daily S-LOADEST loads by daily discharge and converting to milligrams per liter. S-LOADEST daily concentrations were similar to measured instantaneous concentrations at all three inflow tributaries (figs. 7-9, table 3). In general, estimated mean daily concentrations followed the seasonal (high-flow/ low-flow) cycles of instantaneous measured concentrations.

\section{Reservoir Hydrodynamics}

Simulated water temperatures in Beaver Lake were compared to 197 depth profiles of temperature measured at seven sites on Beaver Lake (fig. 1). Temperatures were adjusted to the measured values for the model period, January 2006 through December 2010.

Simulated temperatures compared reasonably well with measured temperatures (fig. 10), and differences varied spatially in Beaver Lake for January 2006 through December 2010. Differences in temperature between simulated and measured values decreased from site L2 (segment 5) to site L5 (segment 35). The AME ranged from $1.75^{\circ} \mathrm{C}$ at site $\mathrm{L} 5$ to $2.68^{\circ} \mathrm{C}$ at $\mathrm{L} 2$, and the RMSE ranged from $2.22^{\circ} \mathrm{C}$ at site L5 to $3.35^{\circ} \mathrm{C}$ at site L2 from January 2006 through December 2010 (table 4). Among all the sites, the greatest differences between measured and simulated data occurred in the upstream part of the reservoir, which is the most dynamic part of the reservoir. The upstream part of the reservoir is the shallowest section of Beaver Lake and has more riverine characteristics than the deep downstream part of the reservoir. The upstream part also receives most of the inflow to the reservoir, which creates more dynamic conditions. The greatest differences between simulated and measured temperatures at any given site generally occurred in simulating the location of the thermocline. Higher wind speeds result in more mixing, resulting in a deeper thermocline and lower surface temperatures, whereas lower wind speeds result in a shallower thermocline and higher surface temperatures. Differences in the thermocline depth between the simulated and measured vertical profiles resulted in high temperature errors because of the rapid change and differences in water temperature with depth.

\section{Dissolved Solids, Chloride, and Sulfate Concentrations}

Simulated DS, $\mathrm{Cl}$, and $\mathrm{SO}_{4}$ concentrations in model segments 2, 5, 48, 14, 16, 23, and 35 matched well with measured concentrations at lake sites L1, L2, L9, L10, L3, L4, and L5, respectively (figs. 11-16). The greatest differences between measured and simulated $\mathrm{DS}, \mathrm{Cl}$, and $\mathrm{SO}_{4}$ concentrations occurred at the upstream sites on the White River main stem in Beaver Lake: White River near Goshen (site L1, model segment 2) and Beaver Lake at Highway 412 (site L2, model segment 5). The higher measured concentrations likely resulted from wastewater discharges upstream from station L1 that were not included in the model input, based on the measured and simulated increases in DS, $\mathrm{Cl}$, and $\mathrm{SO}_{4}$ concentrations between White River near Fayetteville (site S1) and White River near Goshen (site L1) (figs. 7-8). Not including sites L1 and L2, the AME for DS for sites L3, L4, L5, L9, and L10 ranged from $7.64 \mathrm{mg} / \mathrm{L}$ at site $\mathrm{L} 10$ to $11.5 \mathrm{mg} / \mathrm{L}$ at $\mathrm{L} 9$, and the RMSE ranged from 10.4 $\mathrm{mg} / \mathrm{L}$ at site $\mathrm{L} 5$ to $15.2 \mathrm{mg} / \mathrm{L}$ at site $\mathrm{L} 9$ from January 2006 through December 2010 (figs. 11-12, table 4). The AME for $\mathrm{Cl}$ ranged from $0.224 \mathrm{mg} / \mathrm{L}$ at site $\mathrm{L} 5$ to $1.20 \mathrm{mg} / \mathrm{L}$ at site $\mathrm{L} 9$, and the RMSE ranged from $0.286 \mathrm{mg} / \mathrm{L}$ at site $\mathrm{L} 5$ to 1.37 $\mathrm{mg} / \mathrm{L}$ at site L9 from January 2006 through December 2010 (figs. 13-14, table 4). The AME for $\mathrm{SO}_{4}$ ranged from 1.27 $\mathrm{mg} / \mathrm{L}$ at site $\mathrm{L} 4$ to $1.60 \mathrm{mg} / \mathrm{L}$ at site $\mathrm{L} 3$, and the RMSE ranged from $1.51 \mathrm{mg} / \mathrm{L}$ at site $\mathrm{L} 4$ to $1.95 \mathrm{mg} / \mathrm{L}$ at site $\mathrm{L} 9$ from January 2006 through December 2010 (figs. 15-16, table 4). 

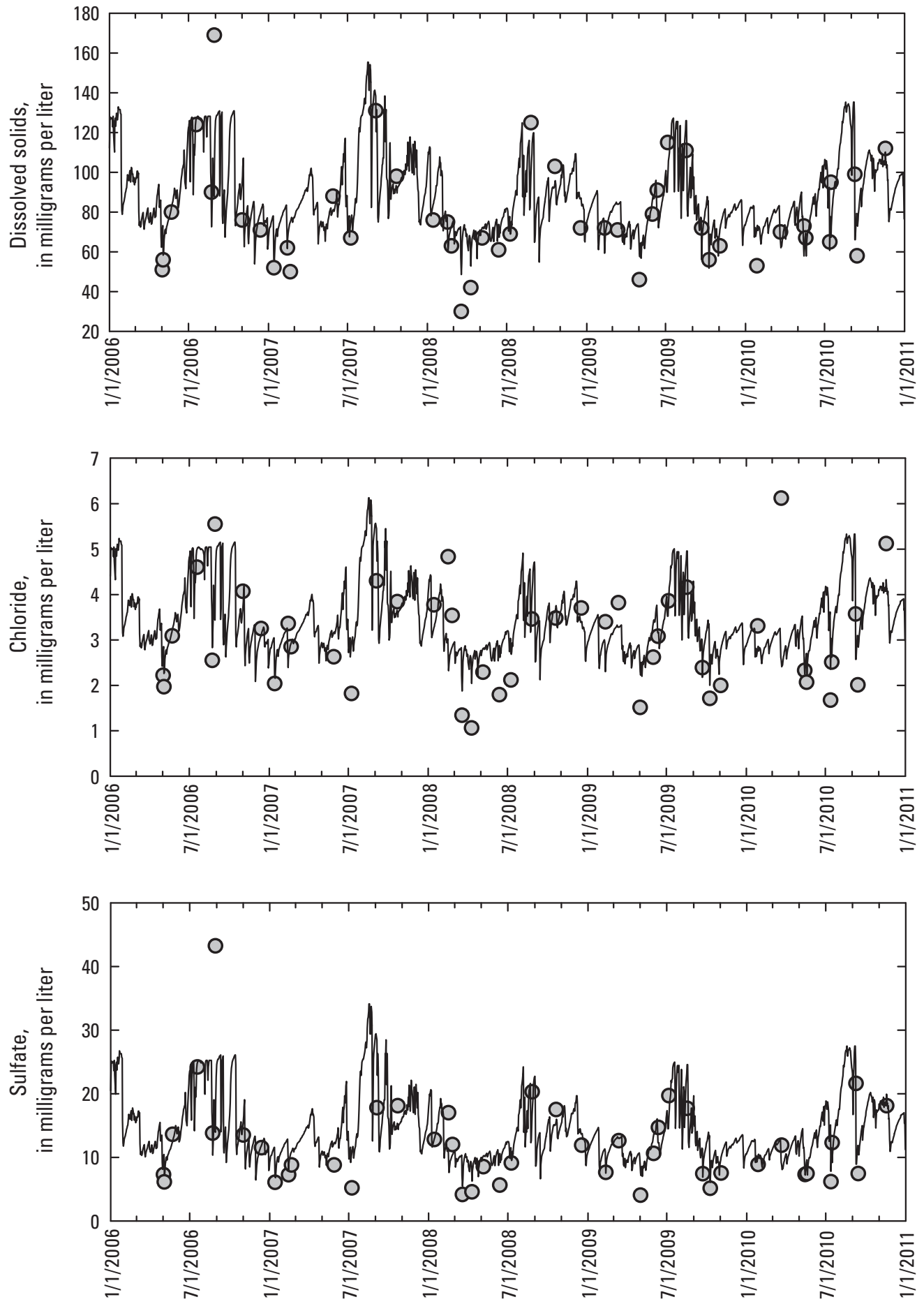

Date

\section{EXPLANATION}

O Measured concentration

Estimated concentration time series

Figure 7. Time-series distributions of measured and S-LOADEST estimated dissolved solids, chloride, and sulfate concentrations at White River (site S1). 

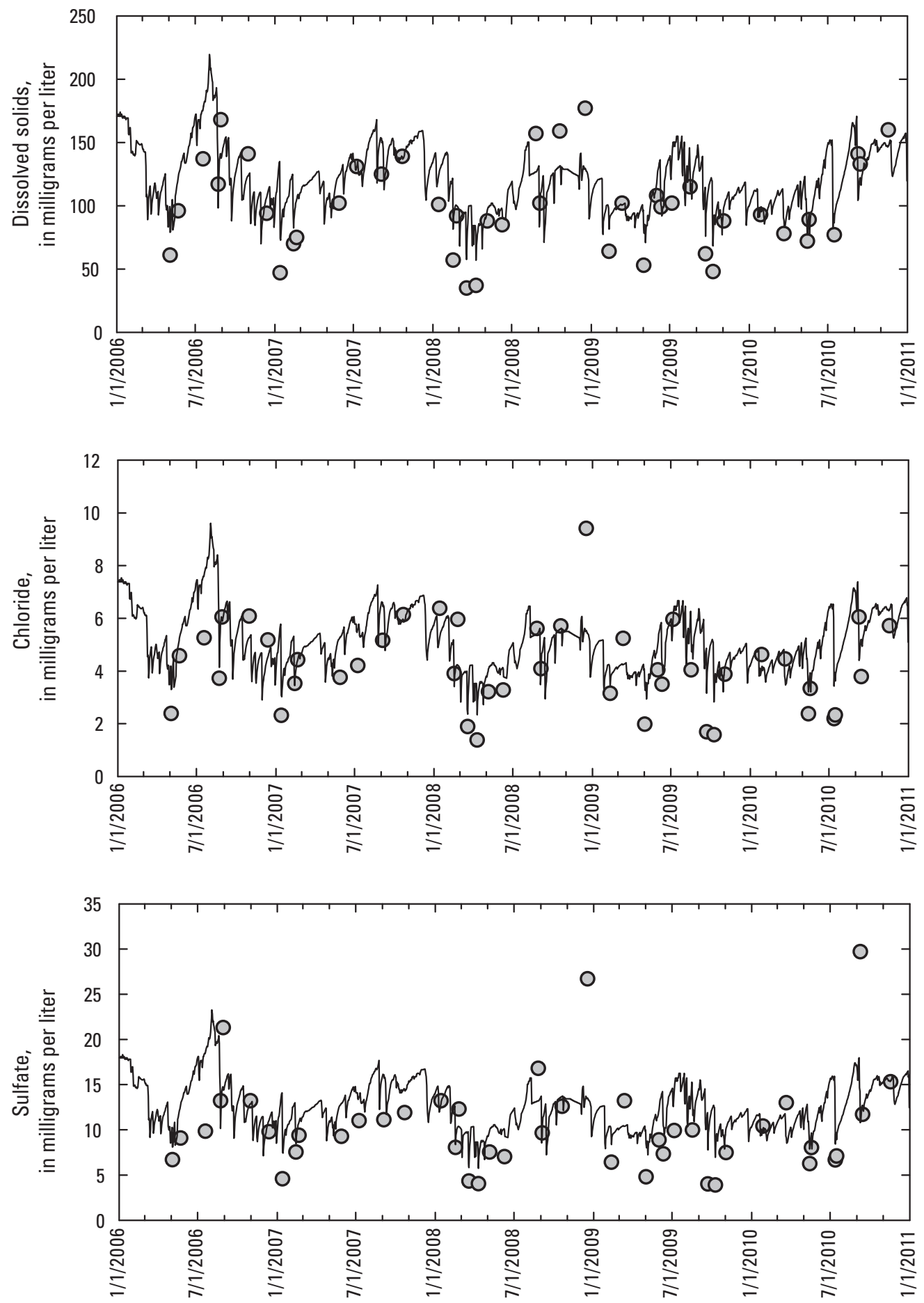

Date

\section{EXPLANATION}

O Measured concentration

Estimated concentration time series

Figure 8. Time-series distributions of measured and S-LOADEST estimated dissolved solids, chloride, and sulfate concentrations at Richland Creek (site S2). 

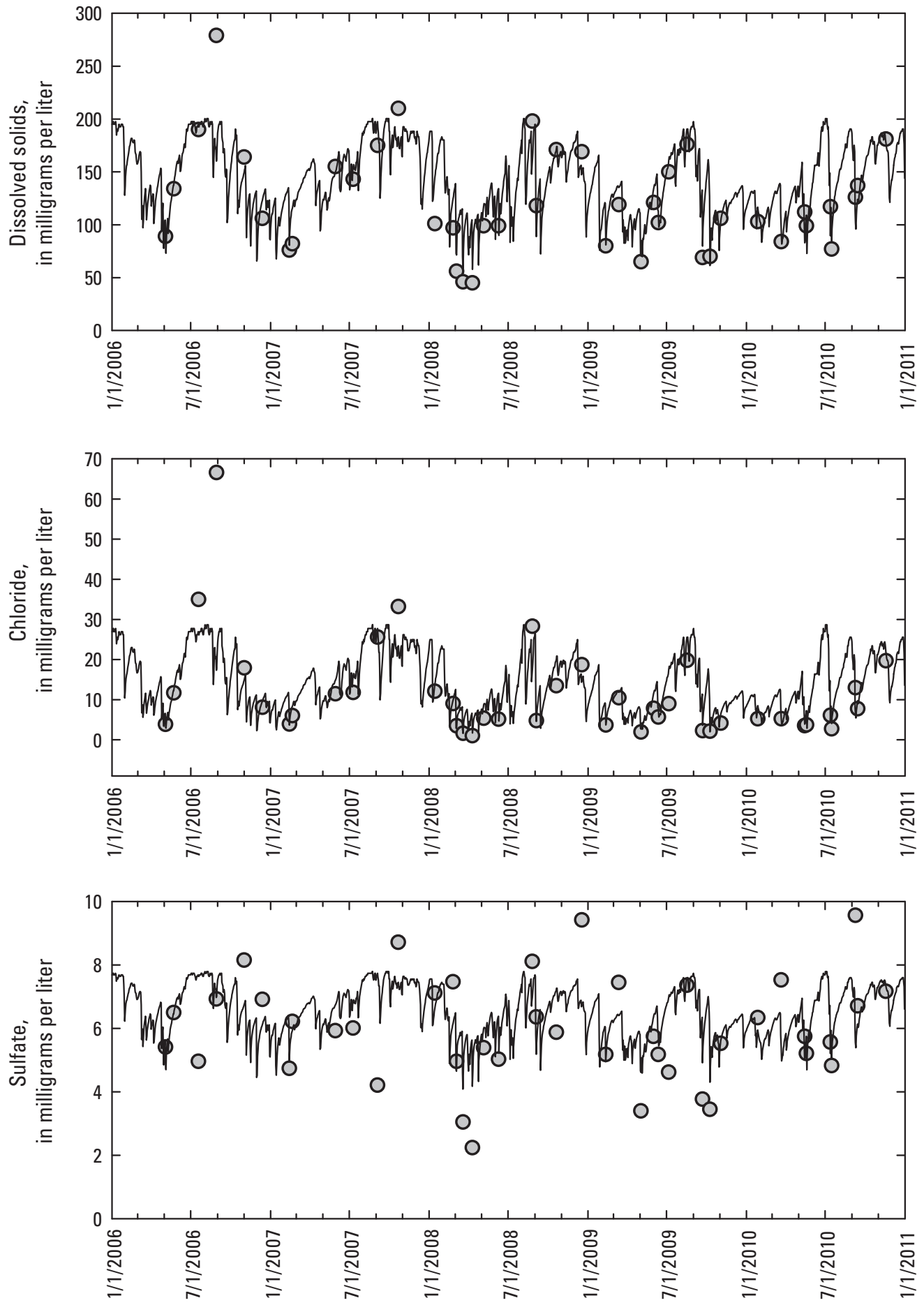

Date

\section{EXPLANATION}

O Measured concentration

Estimated concentration time series

Figure 9. Time-series distributions of measured and S-LOADEST estimated dissolved solids, chloride, and sulfate concentrations at War Eagle Creek (site S3). 
Table 3. Statistics measuring error between measured and S-LOADEST estimated dissolved solids, chloride, and sulfate concentrations at White River (S1), Richland Creek (S2), and War Eagle Creek (S3).

[AME, absolute mean error; RMSE, root mean square error; DS, dissolved solid; $\mathrm{Cl}$, chloride; $\mathrm{SO}_{4}$, sulfate]

\begin{tabular}{|c|c|c|c|c|c|c|}
\hline \multirow[b]{2}{*}{ Constituent } & \multicolumn{2}{|c|}{ White River (S1) } & \multicolumn{2}{|c|}{ Richland Creek (S2) } & \multicolumn{2}{|c|}{ War Eagle Creek (S3) } \\
\hline & AME & RMSE & AME & RMSE & AME & RMSE \\
\hline DS & 12.8 & 18.2 & 19.2 & 22.9 & 17.9 & 26.1 \\
\hline $\mathrm{SO}_{4}$ & 3.271 & 5.701 & 3.123 & 4.566 & 2.242 & 6.912 \\
\hline
\end{tabular}

\section{Dissolved Solids, Chloride, and Sulfate Fate and Transport}

Fifteen $\mathrm{DS}, \mathrm{Cl}$, and $\mathrm{SO}_{4}$ fate and transport scenarios were compared to the baseline (calibrated) simulation. Daily DS, $\mathrm{Cl}$, and $\mathrm{SO}_{4}$ concentrations in the baseline simulation from the White River near Fayetteville (site S1) and War Eagle Creek near Hindsville (site S3) (fig. 1), individually and the two tributaries together, were increased by factors of 1.2, 1.5, 2.0, 5.0, and 10.0 times; flow (discharge) remained unchanged. These scenarios resulted in increased inflow DS, $\mathrm{Cl}$, and $\mathrm{SO}_{4}$ loading in each tributary by a factor of 1.2, 1.5, 2.0, 5.0, and 10.0 times baseline. It should be noted again that contributions from the City of Fayetteville's WWTP were not included in either the baseline model or any of the loading scenarios. Daily DS, $\mathrm{Cl}$, and $\mathrm{SO}_{4}$ concentrations in the 15 scenarios were compared to daily baseline concentrations at the seven model segments $(2,5,48,14,16,23$, and 35$)$ corresponding to lake sites L1, L2, L9, L10, L3, L4, and L5, respectively. Daily baseline and scenario concentrations were reported at the seven model segments $2 \mathrm{~m}$ below the surface and $2 \mathrm{~m}$ above the bottom, corresponding to the depths where water samples were collected. A time-series plot of baseline and scenario results from increasing loading scenarios from White River near Fayetteville (site S1) and War Eagle Creek near Hindsville (site S3), individually and the two tributaries together, for each of the seven model segments at $2 \mathrm{~m}$ below the surface was prepared to visualize differences for the period January 2006 through December 2010 (fig. 17A-C). For all three constituents (DS, $\mathrm{Cl}$, and $\mathrm{SO}_{4}$ ), the loads that were increased by factors of $1.2,1.5$, and 2.0 times baseline produced only slightly higher concentrations in the model segments than those in the baseline condition. Much greater separation in concentrations from the baseline condition, at model segments 2, 5, 48, 14, 16, 23, and 35 at $2 \mathrm{~m}$ below the surface, occurred when loads were increased by a factor of 5.0 and 10.0 times baseline loads.

Average daily $\mathrm{DS}, \mathrm{Cl}$, and $\mathrm{SO}_{4}$ concentrations, from January 2006 through December 2010, for each constituent for the baseline and each loading scenario at each of the seven model segments both $2 \mathrm{~m}$ below the surface and 2 $\mathrm{m}$ above the bottom are presented in tables 5-7 and figures 18-26. Concentrations were greater in the reservoir at model segments closer to where the tributaries entered the reservoir: sites L1 and L2 (segments 2 and 5) for increased loads from White River near Fayetteville (site S1) and sites L9 and L10 (segments 48 and 14) for increased loads from War Eagle Creek near Hindsville. Concentrations resulting from the increase in loading became more diluted farther downstream from the source. Differences in concentrations between the baseline condition and the 1.2, 1.5, and 2.0 times baseline concentration scenarios were smaller than the differences in the 5.0 and 10.0 times baseline concentration scenarios. The results for both the $2 \mathrm{~m}$ below the surface and $2 \mathrm{~m}$ above the bottom were similar, with the exception of concentrations resulting from the increased loading factors (5.0 and 10.0 times), where concentrations $2 \mathrm{~m}$ above the bottom were consistently greater than those $2 \mathrm{~m}$ below the surface at most segments. During thermal stratification, inflow water temperature often is lower (more dense) than the surface of the reservoir, which causes the inflow to dip below the warmer surface layer into a layer of equal density, carrying DS, CL, and $\mathrm{SO}_{4}$ with it. During these times, concentrations will be higher in the deeper water than the surface, as shown in the average concentrations at the increased loading rates in tables 5-7 and figures 18-26. 

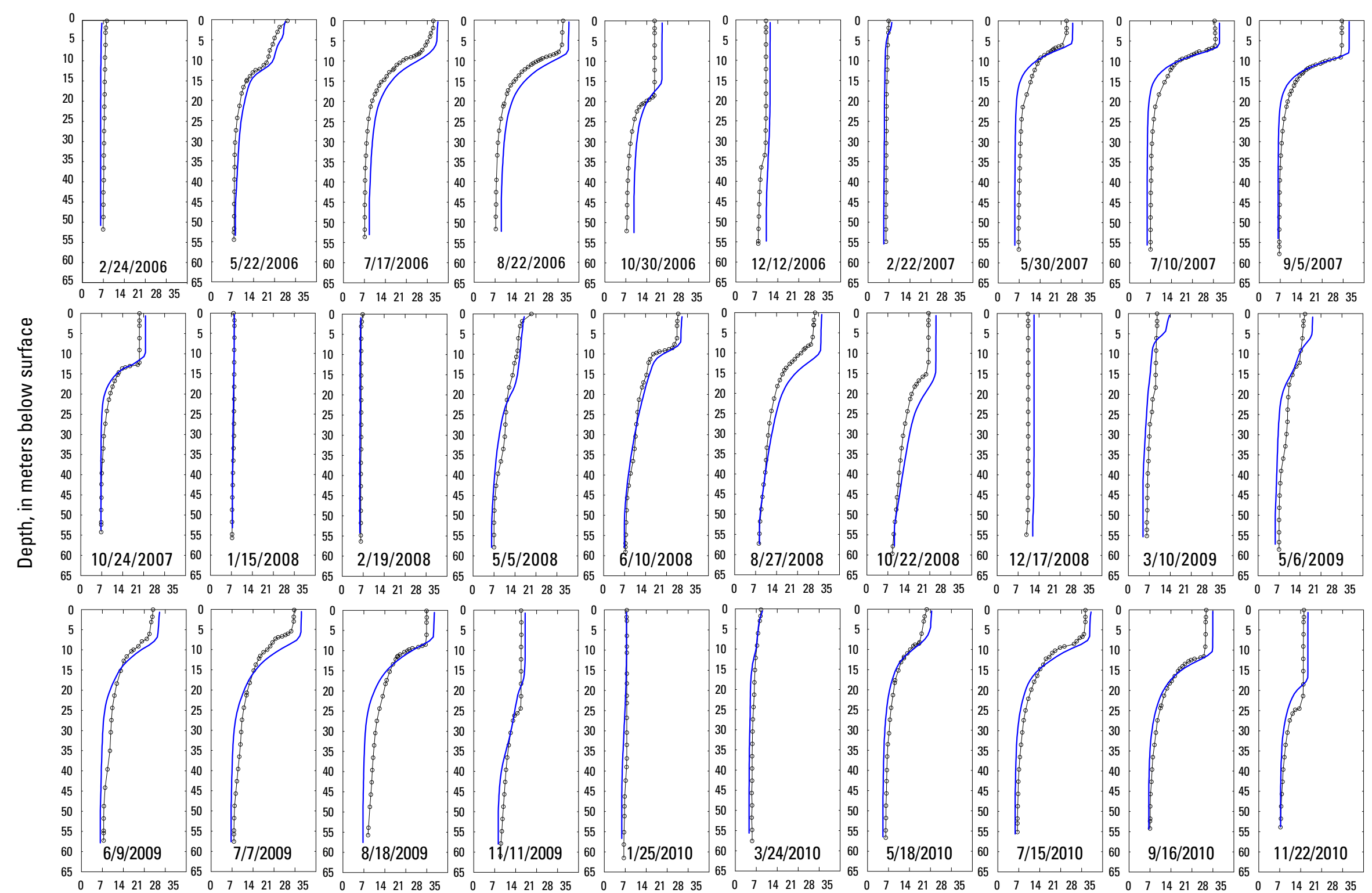

Water temperature, in degrees celsius

EXPLANATION

Measured temperature

Simulated temperature

Figure 10. Selected simulated and measured water-temperature profiles for Beaver Lake at Highway 412 bridge near Eureka Springs, Arkansas (site L5, segment 35). 
Table 4. CE-QUAL-W2 model calibration evaluation statistics for water temperature, dissolved solids, chloride, and sulfate for Beaver Lake sites, January 2006 through December 2010.

[Difference is simulated minus measured]

\begin{tabular}{|c|c|c|c|c|c|c|}
\hline Station & Year & $\begin{array}{l}\text { Minimum } \\
\text { difference }\end{array}$ & $\begin{array}{l}\text { Maximum } \\
\text { difference }\end{array}$ & $\begin{array}{c}\text { Mean } \\
\text { difference }\end{array}$ & $\begin{array}{c}\text { Absolute } \\
\text { mean error }\end{array}$ & $\begin{array}{l}\text { Root mean } \\
\text { square error }\end{array}$ \\
\hline \multicolumn{7}{|c|}{ Temperature, in degrees Celsius } \\
\hline $\begin{array}{l}\text { L2, Beaver Lake at Highway } 412 \\
\quad \text { bridge near Sonora (segment } 5)^{1}\end{array}$ & 2006-2010 & -3.66 & 9.77 & 2.15 & 2.68 & 3.35 \\
\hline $\begin{array}{l}\text { L10, Beaver Lake downstream from } \\
\text { Hickory Creek Landing near } \\
\text { Springdale (segment 14) }\end{array}$ & $2008-2010$ & -4.47 & 7.32 & 1.24 & 2.04 & 2.61 \\
\hline $\begin{array}{l}\text { L3, Beaver Lake near Lowell } \\
\text { (segment 16) }\end{array}$ & $2006-2010$ & -5.31 & 6.84 & 1.35 & 2.30 & 2.77 \\
\hline \multicolumn{7}{|c|}{ Dissolved solids, in milligrams per liter } \\
\hline $\begin{array}{l}\text { L1, White River near Goshen } \\
\quad(\text { segment } 2)^{1}\end{array}$ & $2006-2010$ & -153 & 19.8 & -24.1 & 29.2 & 45.1 \\
\hline $\begin{array}{l}\text { L2, Beaver Lake at Highway } 412 \\
\quad \text { bridge near Sonora (segment } 5)^{1}\end{array}$ & 2006-2010 & -74.7 & 18.3 & -17.7 & 19.3 & 24.7 \\
\hline $\begin{array}{l}\text { L9, War Eagle Creek above White } \\
\text { River near Lowell (segment 48) }\end{array}$ & $2007-2010$ & -50.8 & 14.8 & -5.96 & 11.5 & 15.2 \\
\hline $\begin{array}{l}\text { L10, Beaver Lake downstream } \\
\text { from Hickory Creek landing near } \\
\text { Springdale (segment 14) }\end{array}$ & $2008-2010$ & -27.4 & 5.97 & -5.20 & 7.64 & 10.8 \\
\hline \multicolumn{7}{|c|}{ Chloride, in milligrams per liter } \\
\hline $\begin{array}{l}\text { L1, White River near Goshen } \\
\quad(\text { segment } 2)^{1}\end{array}$ & $2006-2010$ & -39.1 & 0.725 & -3.92 & 4.17 & 8.13 \\
\hline $\begin{array}{l}\text { L2, Beaver Lake at Highway } 412 \\
\quad \text { bridge near Sonora (segment } 5)^{1}\end{array}$ & 2006-2010 & -7.60 & 1.04 & -1.68 & 1.83 & 2.60 \\
\hline $\begin{array}{l}\text { L9, War Eagle Creek above White } \\
\text { River near Lowell (segment 48) }\end{array}$ & $2007-2010$ & -2.10 & 2.41 & 0.80 & 1.20 & 1.37 \\
\hline $\begin{array}{l}\text { L10, Beaver Lake downstream } \\
\text { from Hickory Creek landing near } \\
\text { Springdale (segment 14) }\end{array}$ & $2008-2010$ & -2.35 & 1.01 & 0.04 & 0.65 & 0.81 \\
\hline $\begin{array}{l}\text { L3, Beaver Lake near Lowell } \\
\quad \text { (segment 16) }\end{array}$ & 2006-2010 & -2.84 & 1.33 & -0.29 & 0.69 & 0.93 \\
\hline $\begin{array}{l}\text { L4, Beaver Lake at Highway } 12 \\
\text { bridge near Rogers (segment 23) }\end{array}$ & 2006-2010 & -2.50 & 0.92 & -0.33 & 0.56 & 0.74 \\
\hline $\begin{array}{l}\text { L5, Beaver Lake near Eureka } \\
\text { Springs (segment 35) }\end{array}$ & 2006-2010 & -0.82 & 0.58 & -0.01 & 0.22 & 0.29 \\
\hline
\end{tabular}


Table 4. CE-QUAL-W2 model calibration evaluation statistics for water temperature, dissolved solids, chloride, and sulfate for Beaver Lake sites, January 2006 through December 2010.—Continued

[Difference is simulated minus measured]

\begin{tabular}{|c|c|c|c|c|c|c|}
\hline Station & Year & $\begin{array}{l}\text { Minimum } \\
\text { difference }\end{array}$ & $\begin{array}{l}\text { Maximum } \\
\text { difference }\end{array}$ & $\begin{array}{c}\text { Mean } \\
\text { difference }\end{array}$ & $\begin{array}{c}\text { Absolute } \\
\text { mean error }\end{array}$ & $\begin{array}{l}\text { Root mean } \\
\text { square error }\end{array}$ \\
\hline \multicolumn{7}{|c|}{ Sulfate, in milligrams per liter } \\
\hline $\begin{array}{l}\text { L2, Beaver Lake at Highway } 412 \\
\text { bridge near Sonora (segment } 5)^{1}\end{array}$ & 2006-2010 & -7.24 & 8.89 & 0.10 & 2.49 & 3.12 \\
\hline $\begin{array}{l}\text { L10, Beaver Lake downstream } \\
\text { from Hickory Creek landing near } \\
\text { Springdale (segment 14) }\end{array}$ & 2008-2010 & -2.03 & 2.33 & 0.916 & 1.40 & 1.55 \\
\hline $\begin{array}{l}\text { L3, Beaver Lake near Lowell } \\
\quad \text { (segment 16) }\end{array}$ & 2006-2010 & -3.47 & 5.87 & 1.31 & 1.60 & 1.93 \\
\hline
\end{tabular}

${ }^{1}$ Model simulation does not include dissolved solids, chloride, and sulfate constituents from the Fayetteville, Arkansas, wastewater-treatment plant, which influence measured concentrations. 

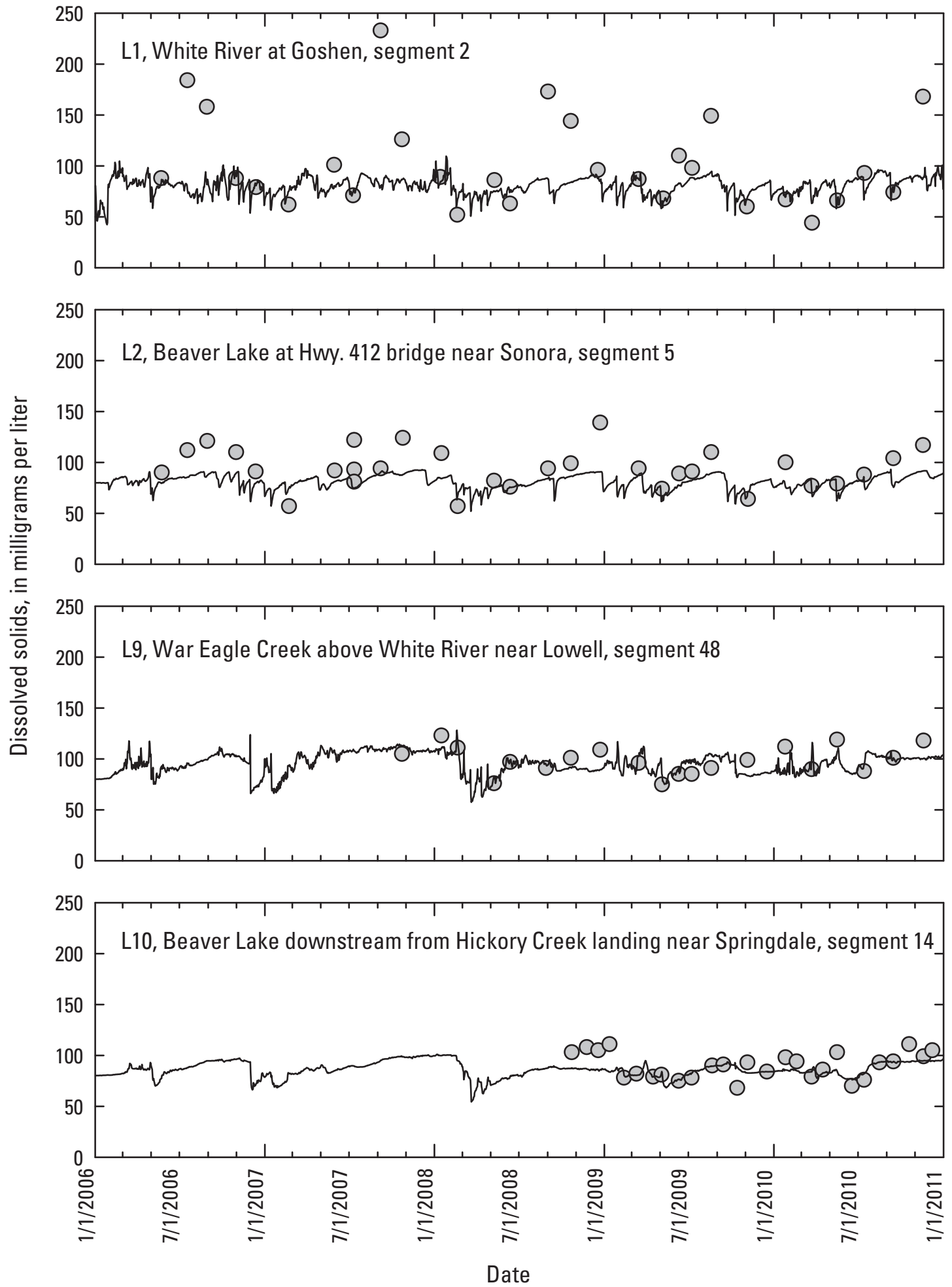

\section{EXPLANATION}

O Measured concentration

Simulated concentration

Figure 11. Simulated and measured dissolved solids concentrations 2 meters $(\mathrm{m})$ below the surface in Beaver Lake, Arkansas. 


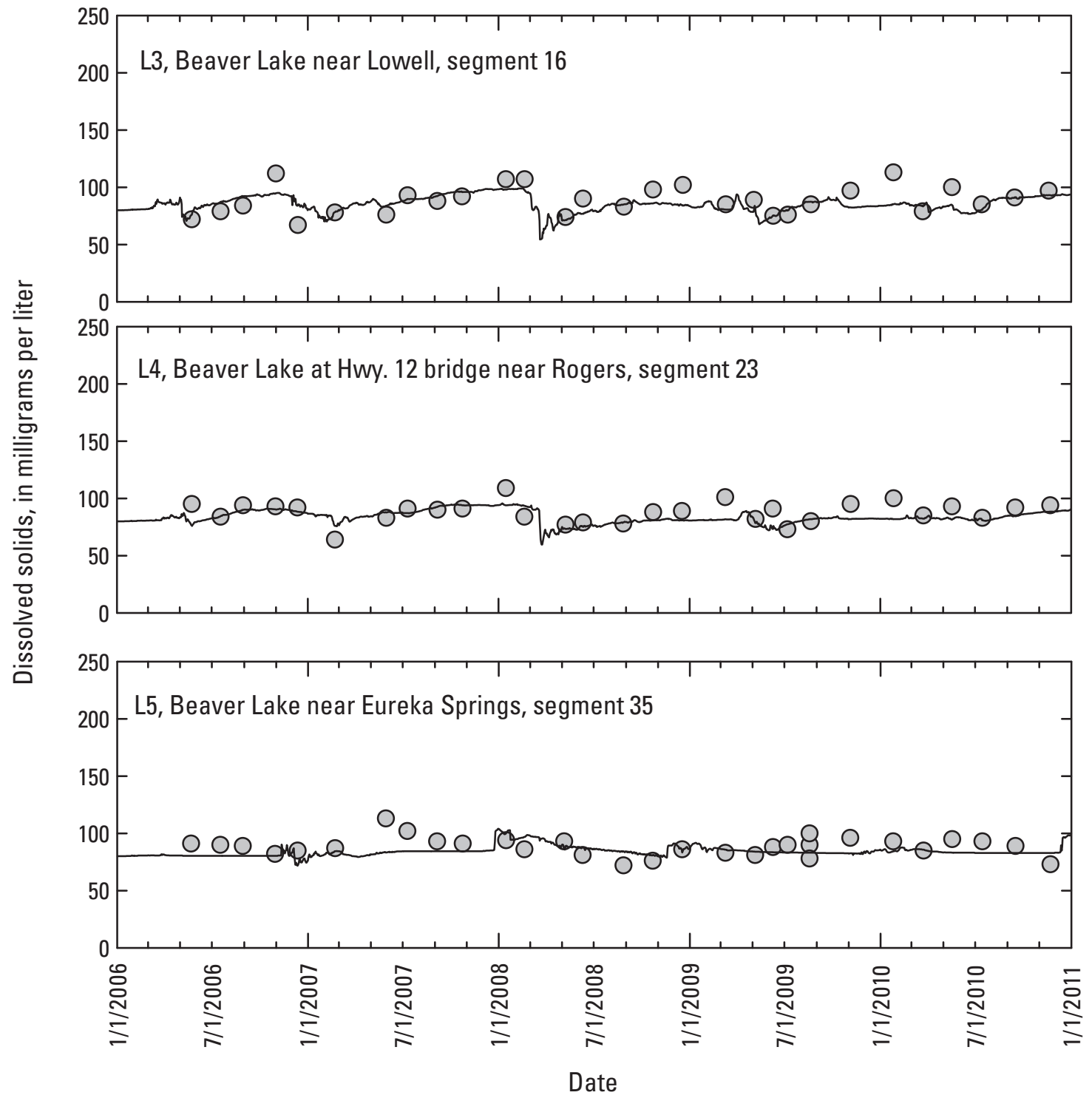

EXPLANATION

O Measured concentration

Simulated concentration

Figure 11. Simulated and measured dissolved solids concentrations 2 meters $(\mathrm{m})$ below the surface in Beaver Lake, Arkansas.-Continued 

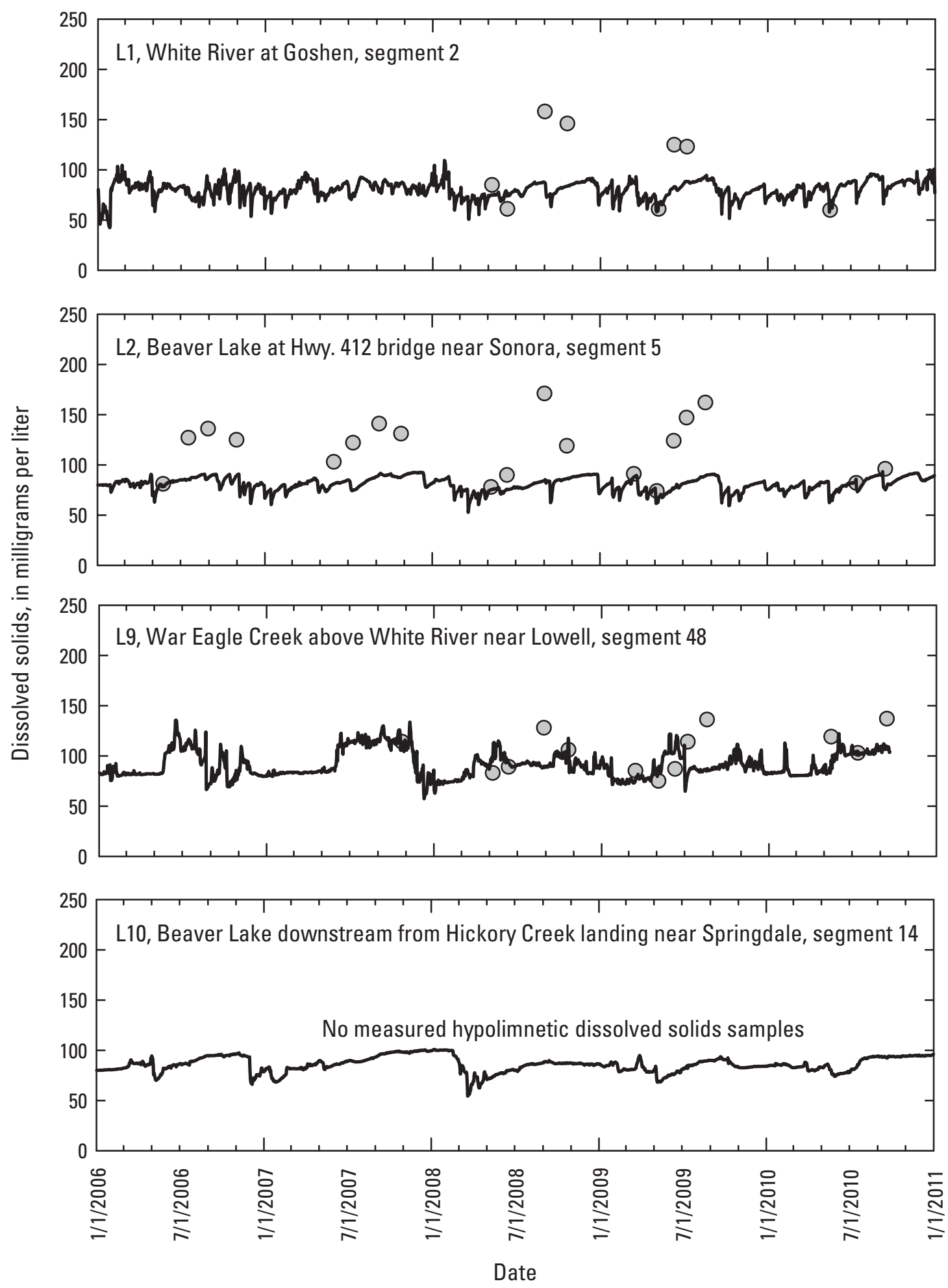

\section{EXPLANATION}

O Measured concentration

Simulated concentration

Figure 12. Simulated and measured dissolved solids concentrations 2 meters $(\mathrm{m})$ above the bottom in Beaver Lake, Arkansas. 

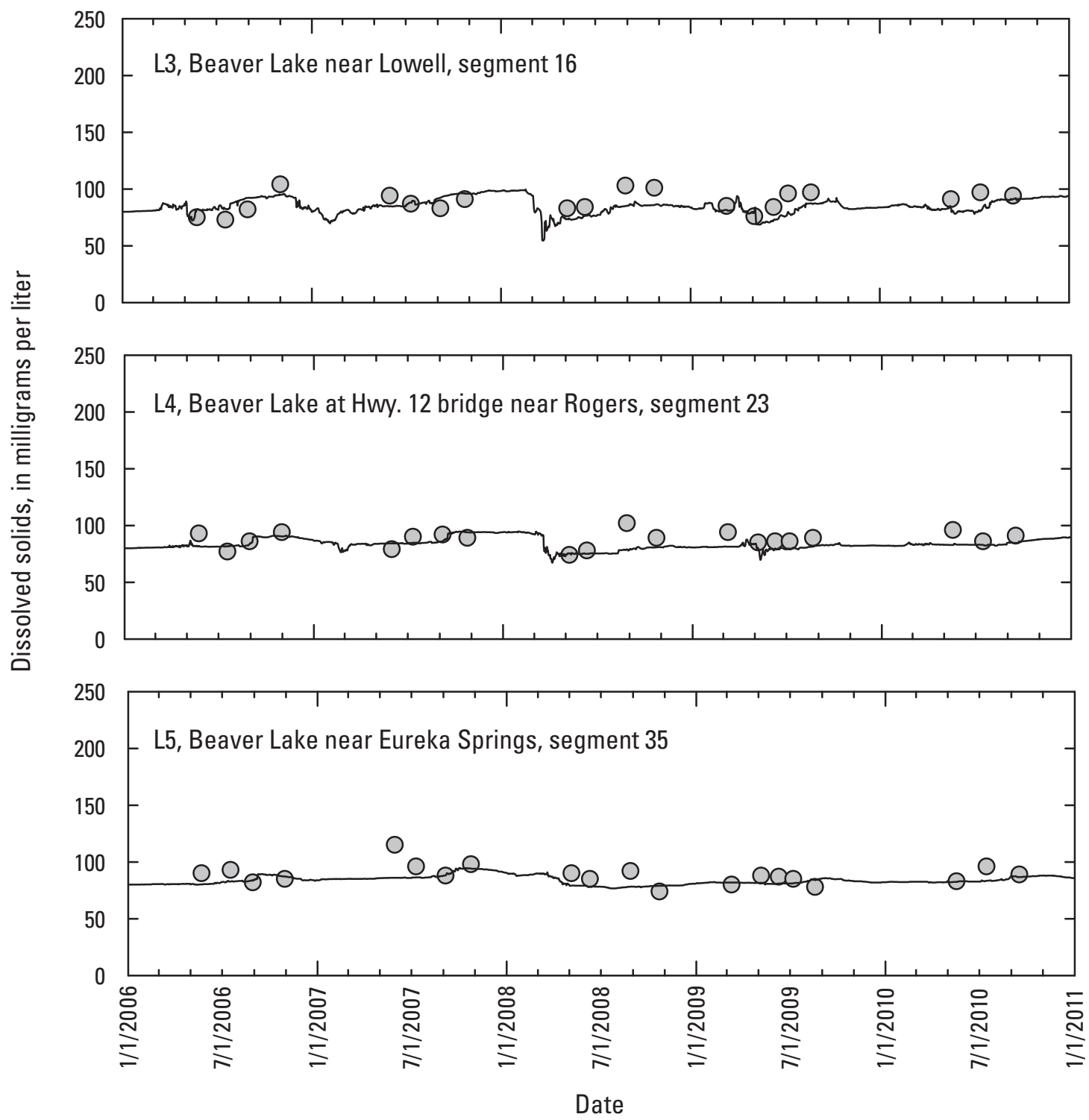

\section{EXPLANATION}

O Measured concentration

Simulated concentration

Figure 12. Simulated and measured dissolved solids concentrations 2 meters $(\mathrm{m})$ above the bottom in Beaver Lake, Arkansas.-Continued 

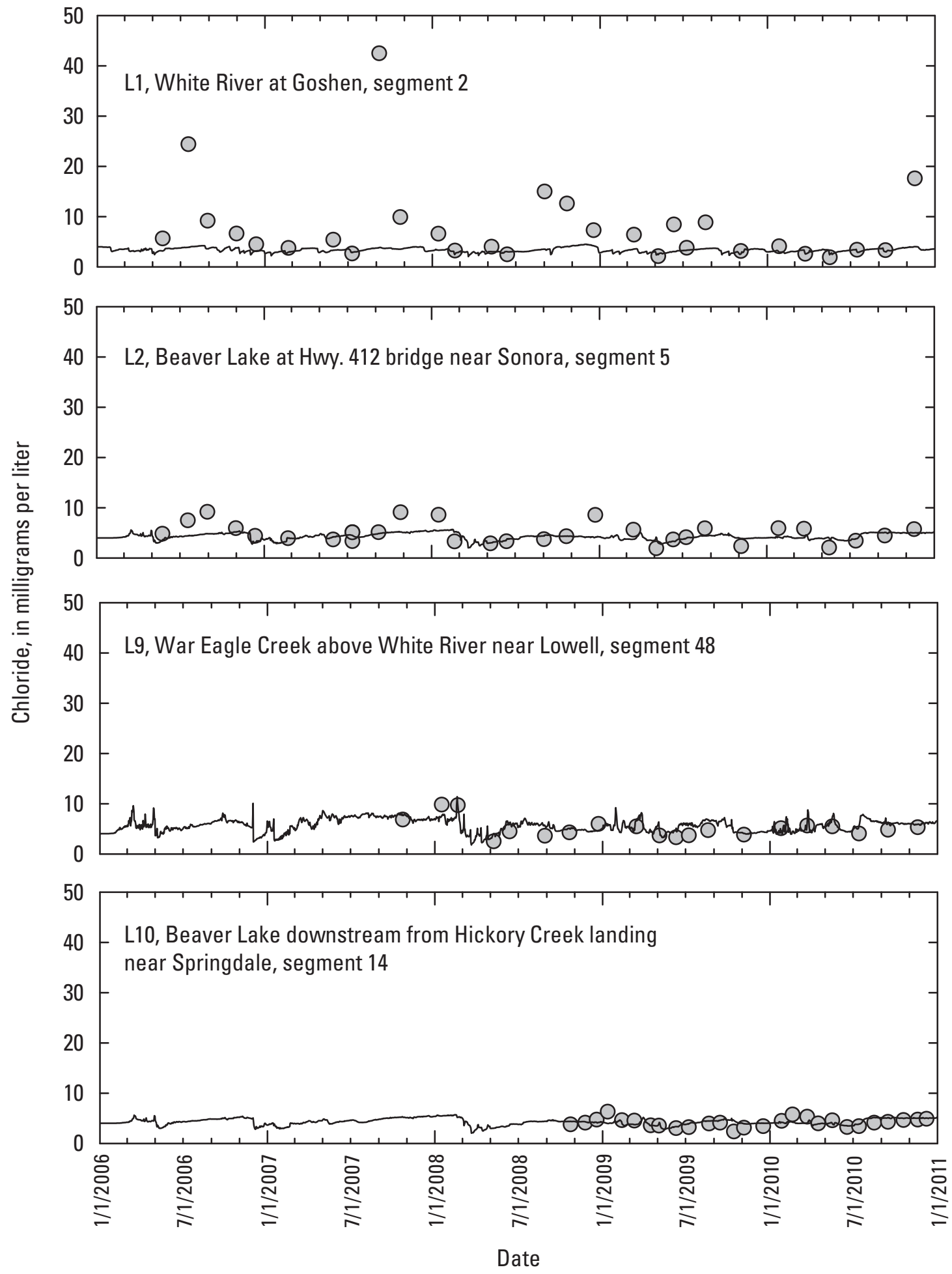

\section{EXPLANATION}

Measured concentration

Simulated concentration

Figure 13. Simulated and measured chloride concentrations 2 meters ( $\mathrm{m}$ ) below the surface in Beaver Lake, Arkansas. 

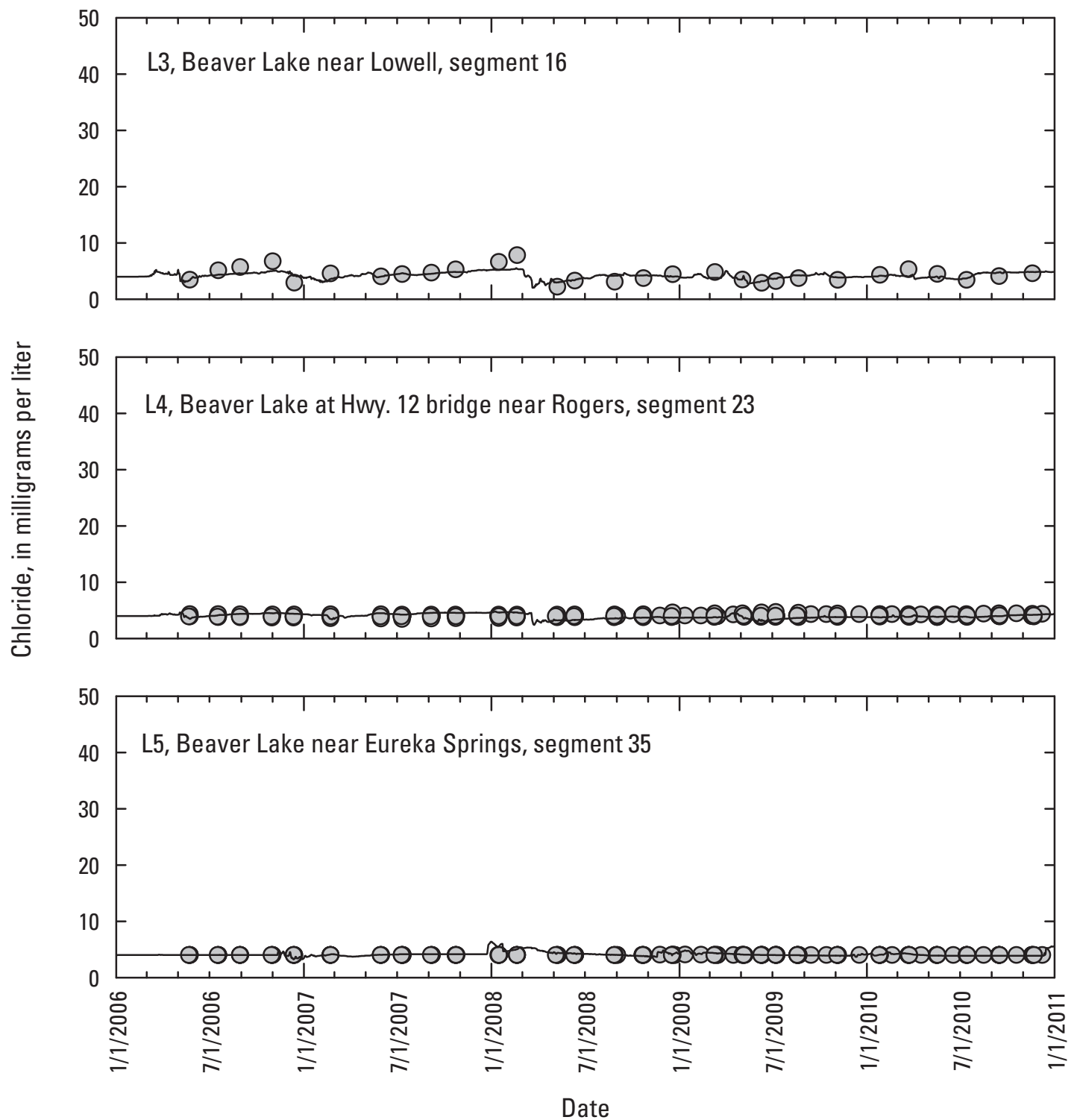

\section{EXPLANATION}

O Measured concentration

Simulated concentration

Figure 13. Simulated and measured chloride concentrations 2 meters $(\mathrm{m})$ below the surface in Beaver Lake, Arkansas.-Continued 

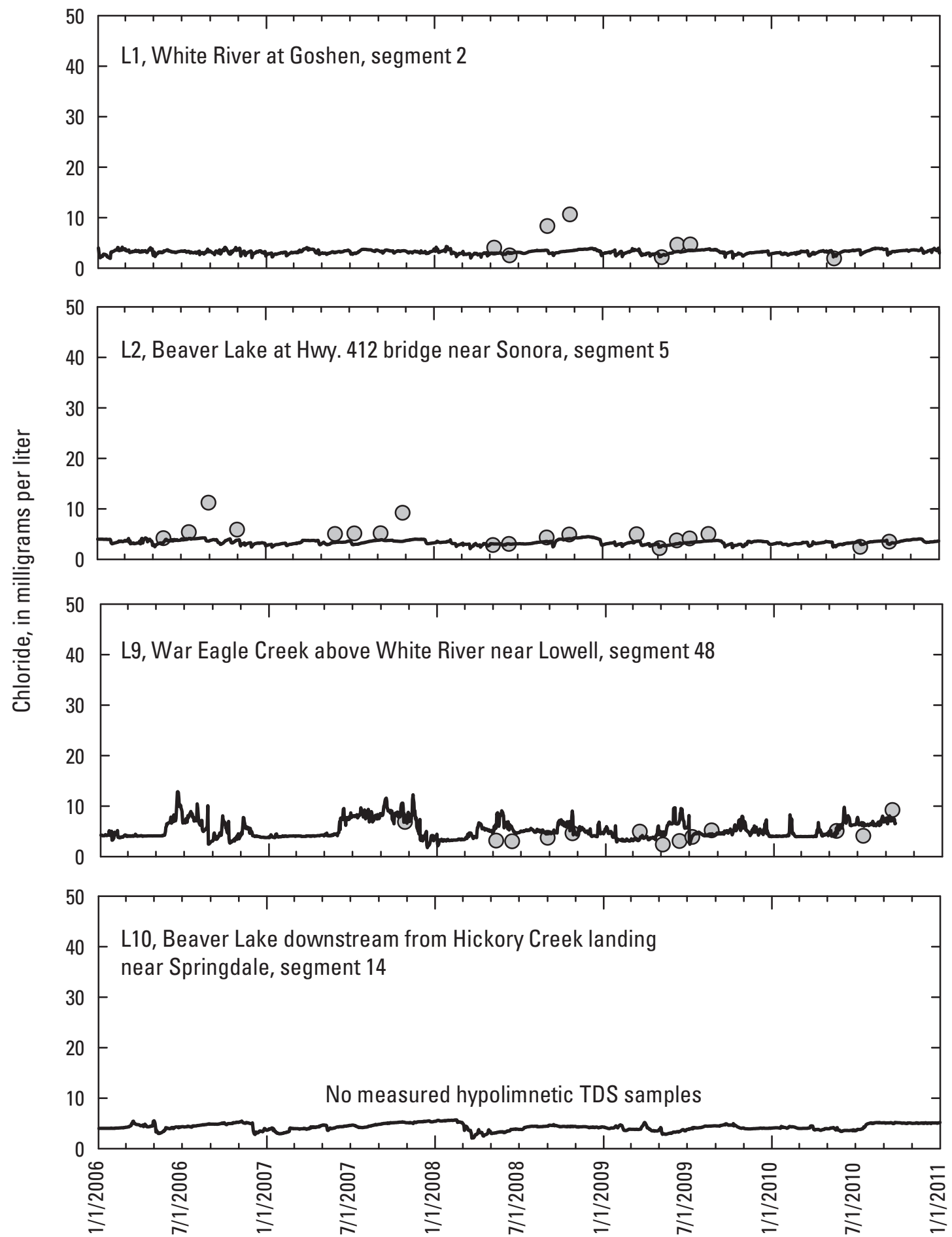

Date

\section{EXPLANATION}

O Measured concentration

Simulated concentration

Figure 14. Simulated and measured chloride concentrations 2 meters $(\mathrm{m})$ above the bottom in Beaver Lake, Arkansas. 

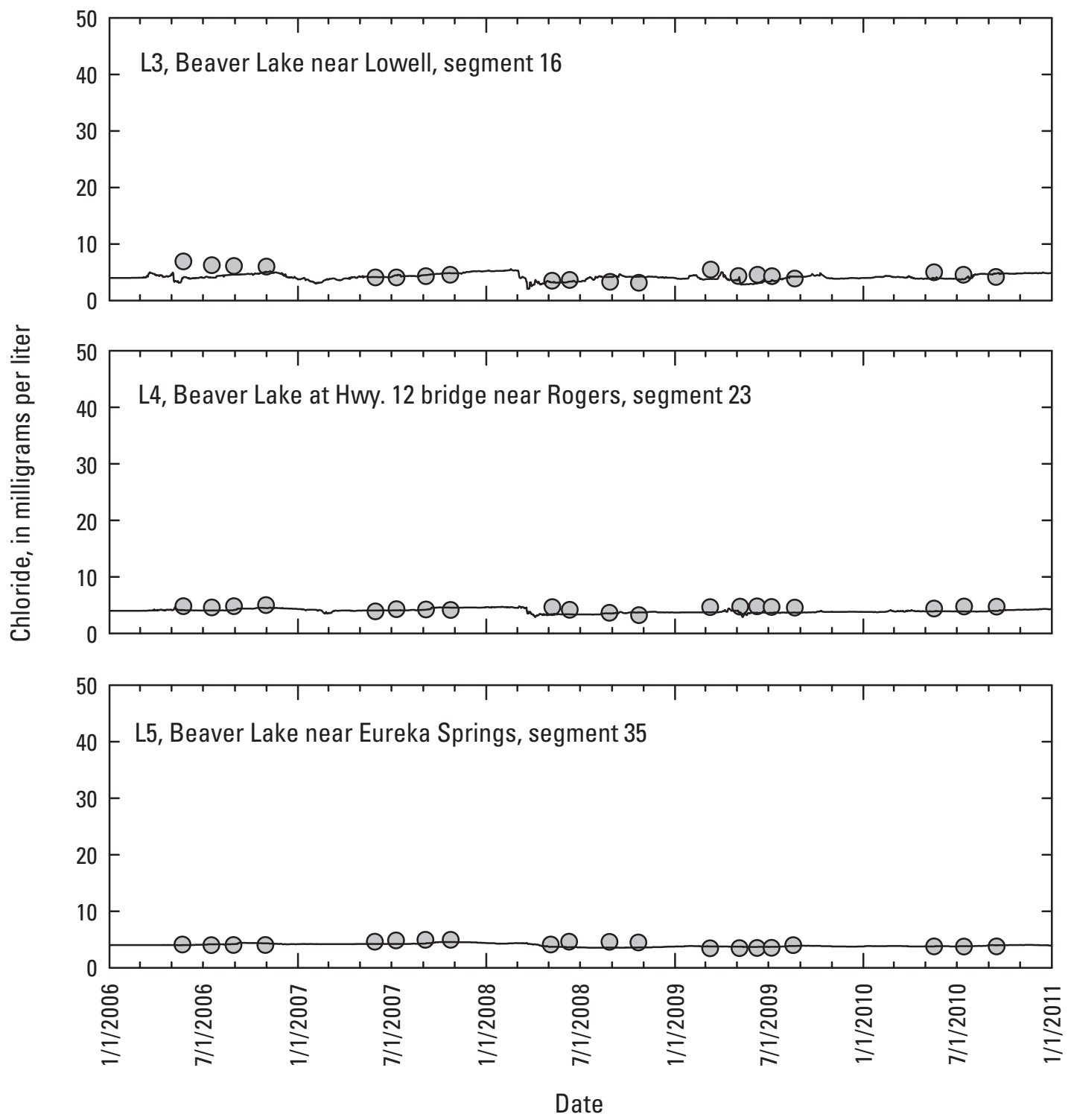

\section{EXPLANATION}

Measured concentration

Simulated concentration

Figure 14. Simulated and measured chloride concentrations 2 meters ( $m$ ) above the bottom in Beaver Lake, Arkansas.-Continued 

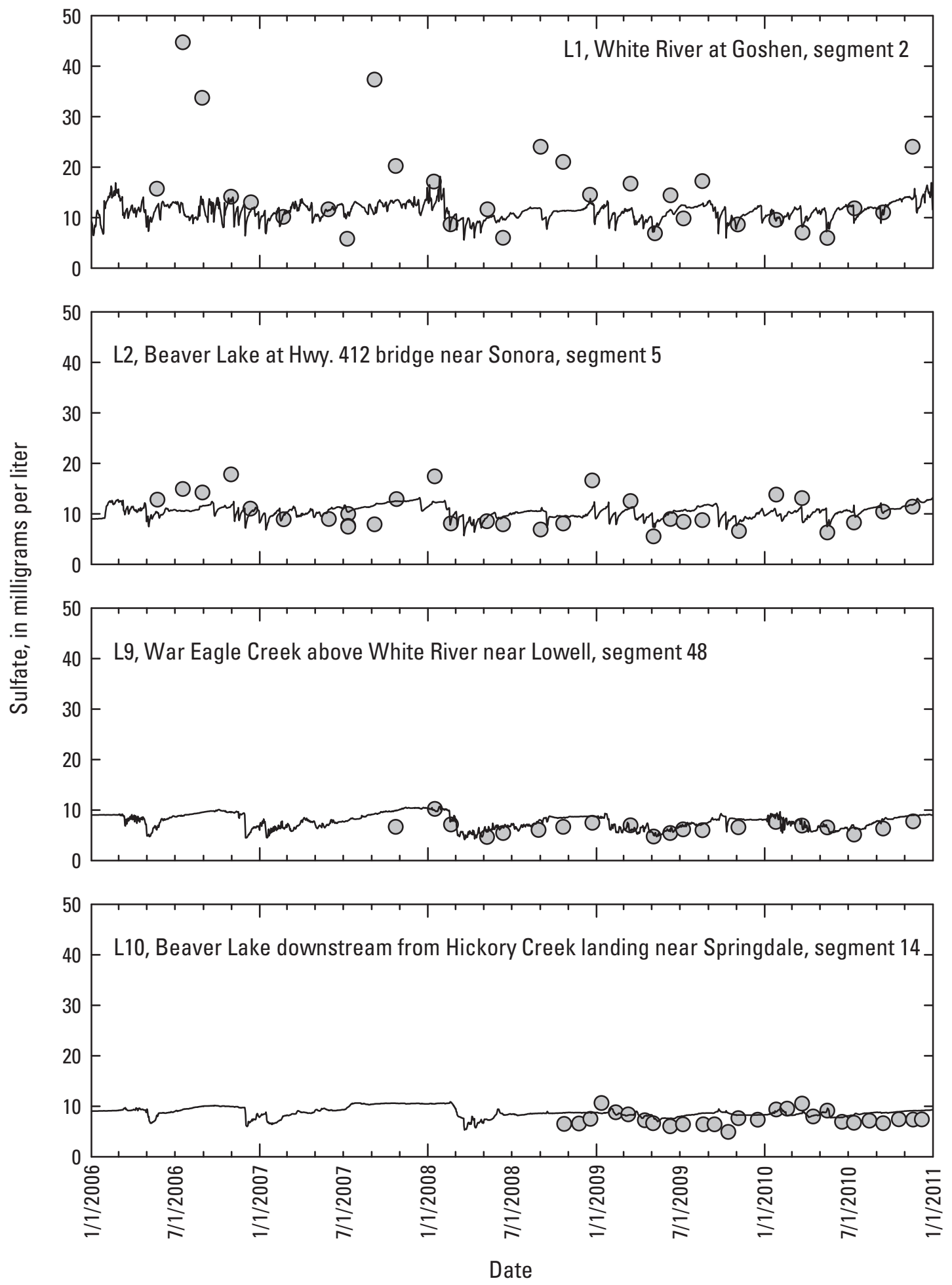

\section{EXPLANATION}

O Measured concentration

Simulated concentration

Figure 15. Simulated and measured sulfate concentrations 2 meters $(\mathrm{m})$ below the surface in Beaver Lake, Arkansas. 

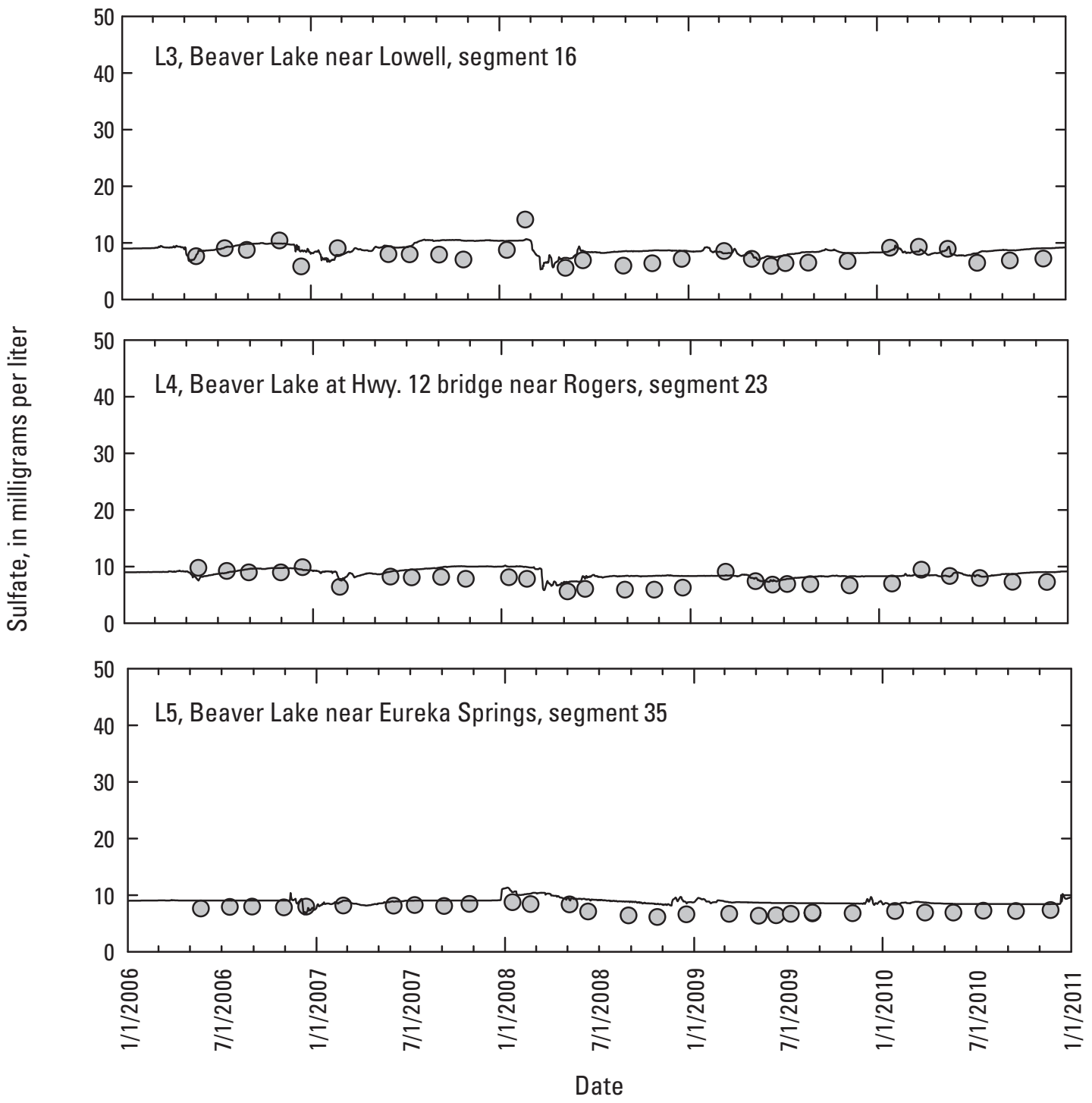

\section{EXPLANATION}

O Measured concentration

- Simulated concentration

Figure 15. Simulated and measured sulfate concentrations 2 meters $(\mathrm{m})$ below the surface in Beaver Lake, Arkansas.-Continued 

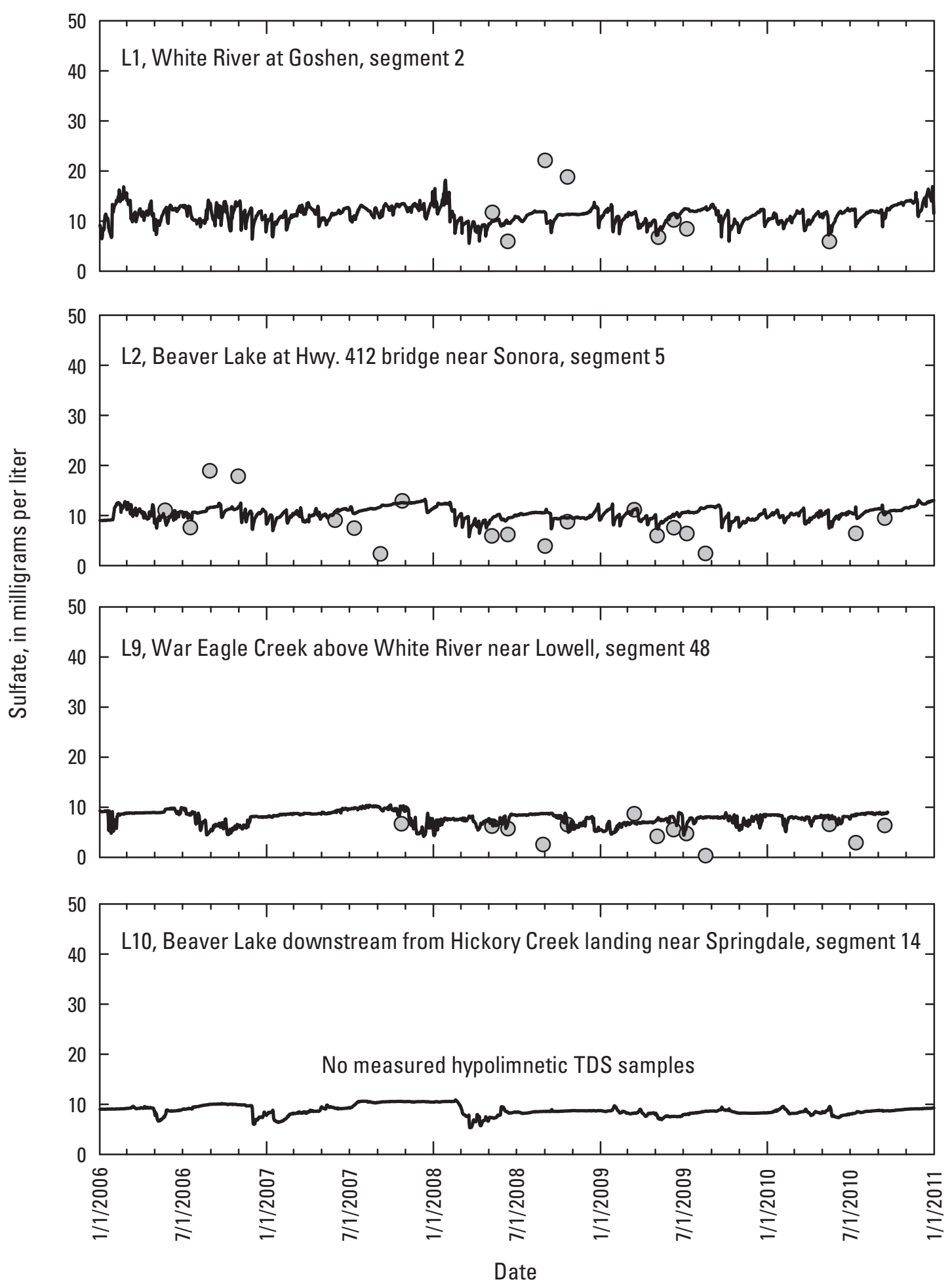

\section{EXPLANATION}

O Measured concentration

Simulated concentration

Figure 16. Simulated and measured sulfate concentrations 2 meters $(\mathrm{m})$ above the bottom in Beaver Lake, Arkansas. 


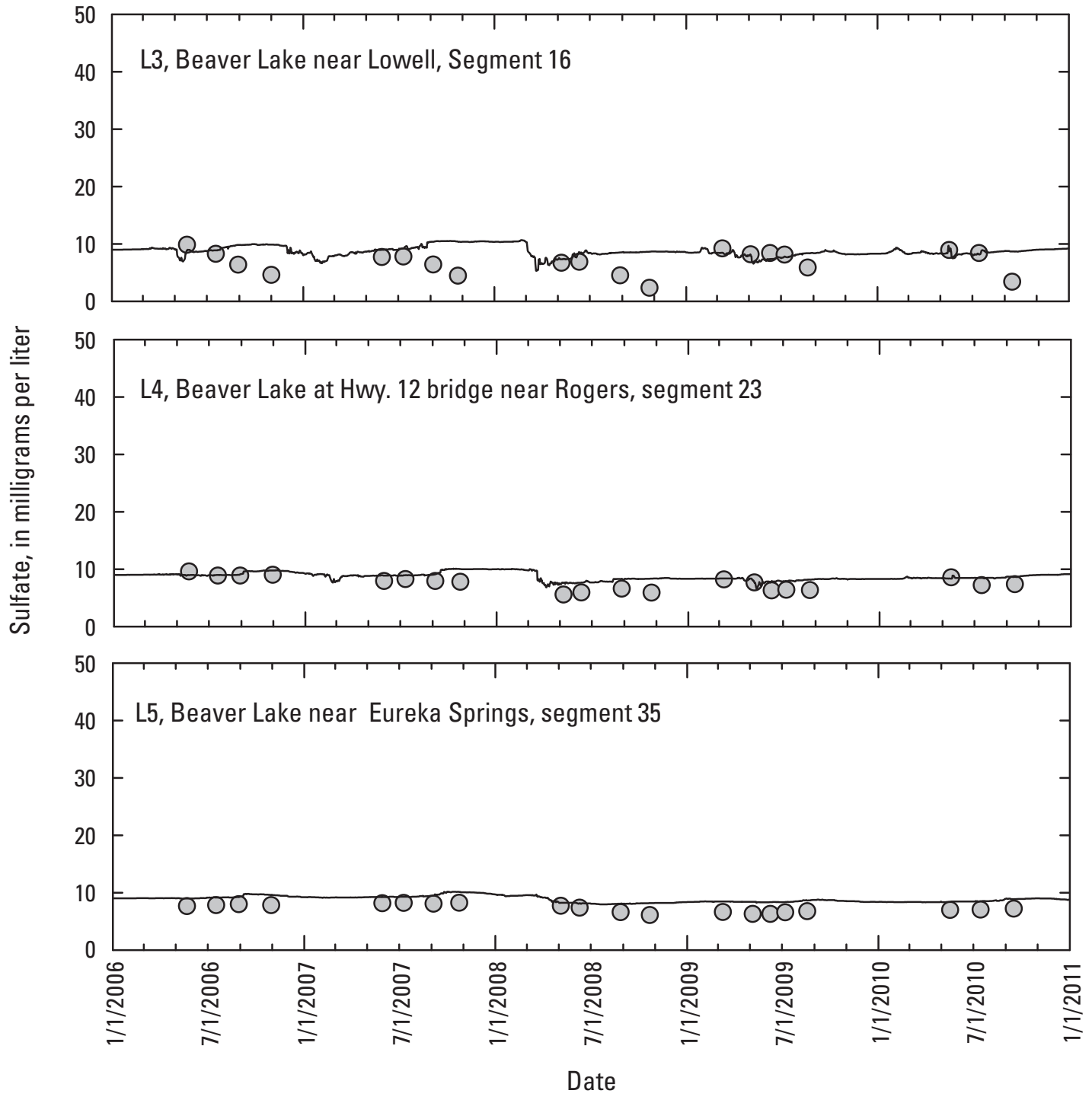

EXPLANATION

O Measured concentration

Simulated concentration

Figure 16. Simulated and measured sulfate concentrations 2 meters $(\mathrm{m})$ above the bottom in Beaver Lake, Arkansas.-Continued 

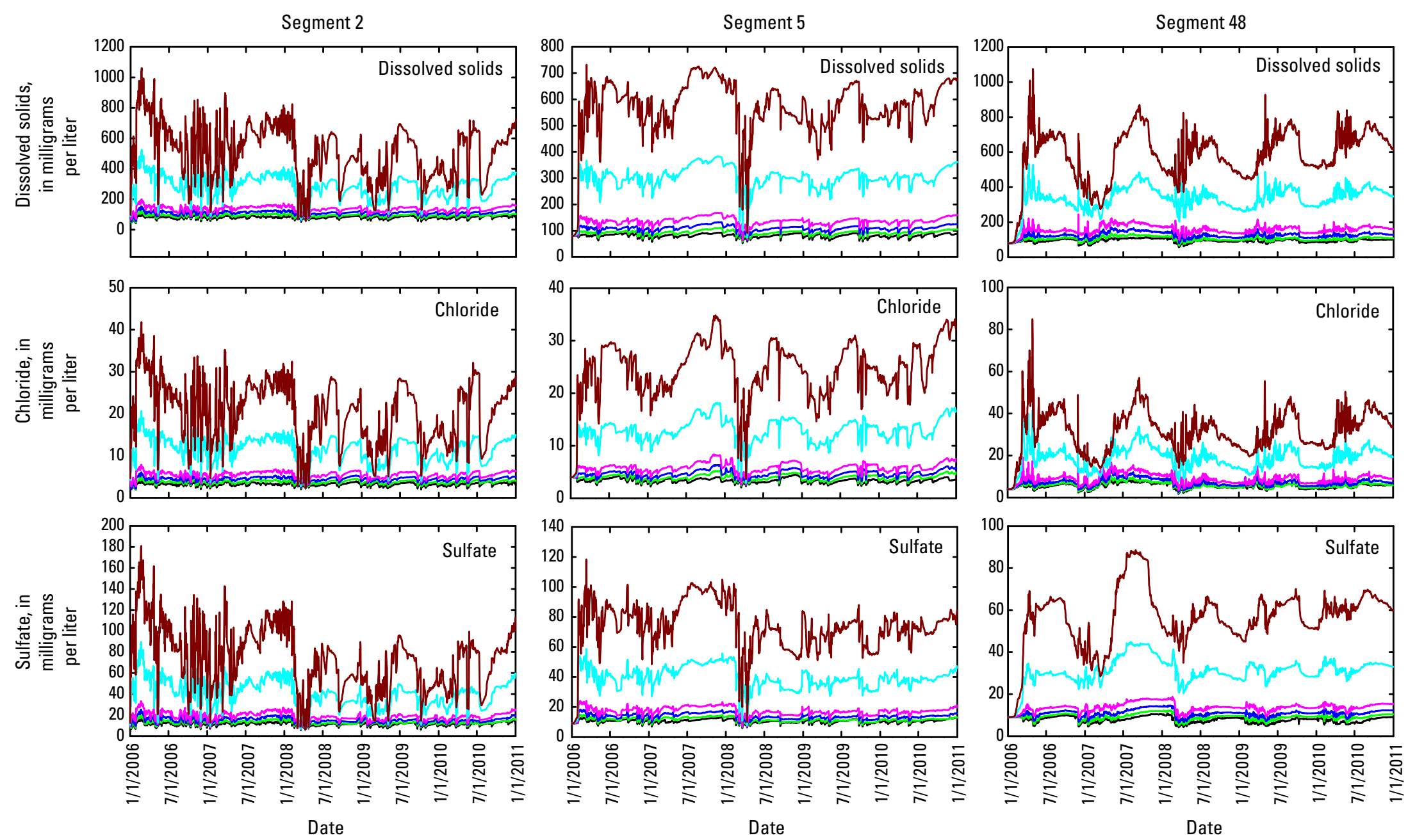

\section{EXPLANATION}

- Baseline (without

wastewater-treatment plant load)

— 1.2 times loading

- 1.5 times loading

- 2.0 times loading

— 5.0 times loading

- 10.0 times loading

Figure 17. Dissolved solids, chloride, and sulfate concentrations 2 meters (m) below the surface at model segments 2, 5, 48, 14, 16, 23 and 35 from baseline model and increased loading scenarios from both White River near Fayetteville, Arkansas, (site S1) and War Eagle Creek near Hindsville, Ark. (site S3). 

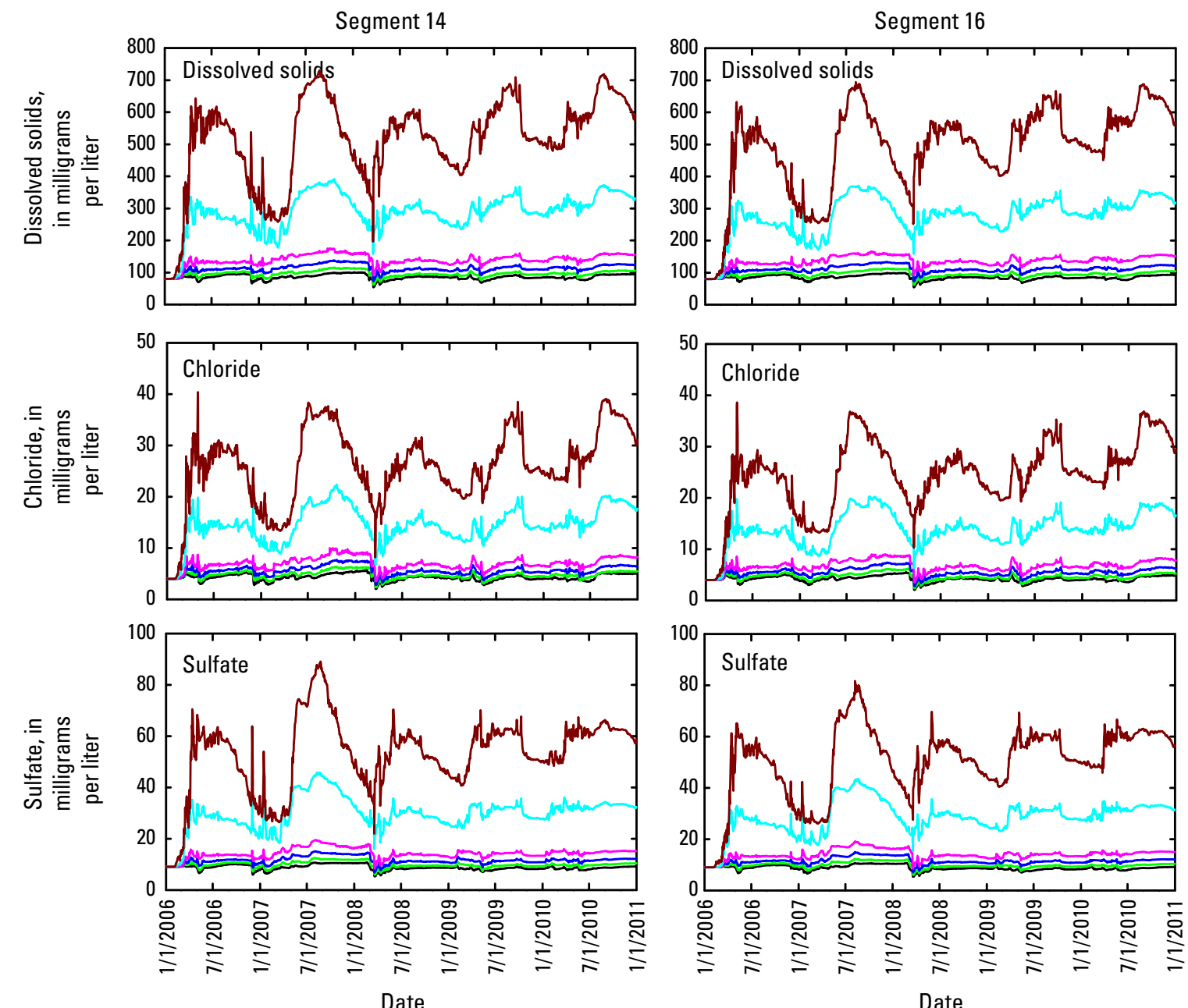

\title{
EXPLANATION
}

\author{
- Baseline (without \\ wastewater-treatment plant load) \\ 1.2 times loading \\ - 1.5 times loading \\ - 2.0 times loading \\ — 5.0 times loading \\ - 10.0 times loading
}

Figure 17. Dissolved solids, chloride, and sulfate concentrations 2 meters $(\mathrm{m})$ below the surface at model segments $2,5,48,14,16,23$ and 35 from baseline model and increased loading scenarios from both White River near Fayetteville, Arkansas, (site S1) and War Eagle Creek near Hindsville, Ark. (site S3).—Continued 

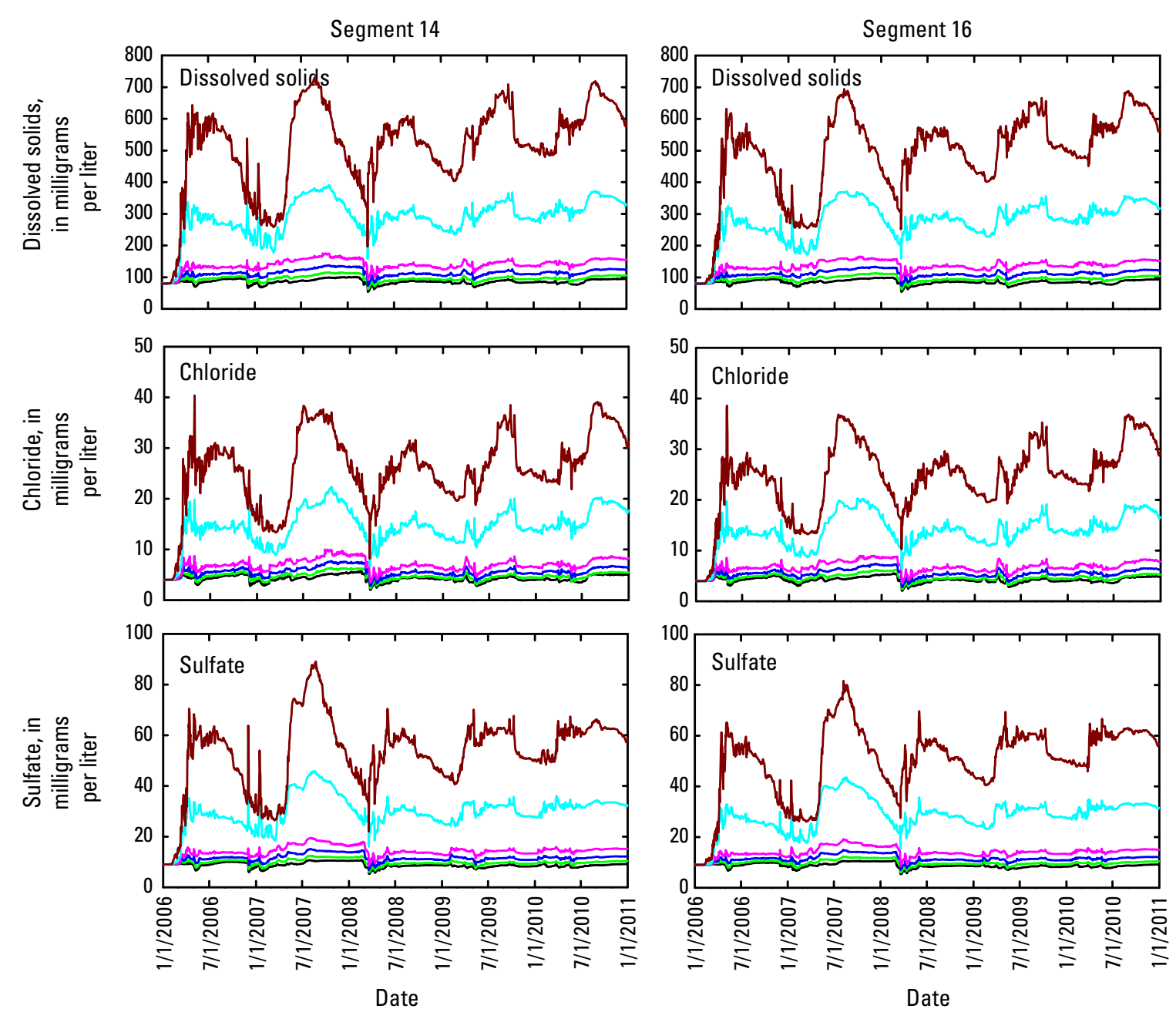

EXPLANATION

\author{
- Baseline (without \\ wastewater-treatment plant load) \\ - 1.2 times loading \\ - 1.5 times loading \\ - 2.0 times loading \\ - 5.0 times loading \\ - 10.0 times loading
}

Figure 17. Dissolved solids, chloride, and sulfate concentrations 2 meters $(\mathrm{m})$ below the surface at model segments 2, 5, 48, 14, 16, 23 and 35 from baseline model and increased loading scenarios from both White River near Fayetteville, Arkansas, (site S1) and War Eagle Creek near Hindsville, Ark. (site S3).-Continued 
Table 5. Average daily dissolved solids, chloride, and sulfate concentrations for baseline condition and increasing loading factor scenarios from White River near Fayetteville (site S1) only, for the period January 2006 through December 2010, 2 meters (m) below the surface and $2 \mathrm{~m}$ above the bottom at model segments 2, 5, 14, 16, 23, and 35 (fig. 2).

\begin{tabular}{|c|c|c|c|c|c|c|c|c|c|c|c|c|}
\hline \multirow[b]{2}{*}{ Loading factor } & \multicolumn{2}{|c|}{$\begin{array}{c}\text { Segment } 2 \\
\text { (site L1) }\end{array}$} & \multicolumn{2}{|c|}{$\begin{array}{l}\text { Segment } 5 \\
\text { (site L2) }\end{array}$} & \multicolumn{2}{|c|}{$\begin{array}{l}\text { Segment } 14 \\
\text { (site L10) }\end{array}$} & \multicolumn{2}{|c|}{$\begin{array}{l}\text { Segment } 16 \\
\text { (site L3) }\end{array}$} & \multicolumn{2}{|c|}{$\begin{array}{l}\text { Segment } 23 \\
\text { (site L4) }\end{array}$} & \multicolumn{2}{|c|}{$\begin{array}{l}\text { Segment } 35 \\
\text { (site L5) }\end{array}$} \\
\hline & $\begin{array}{l}2 \text { m below } \\
\text { surface }\end{array}$ & $\begin{array}{c}2 \mathrm{~m} \text { above } \\
\text { bottom }\end{array}$ & $\begin{array}{c}2 \text { m below } \\
\text { surface }\end{array}$ & $\begin{array}{c}2 \mathrm{~m} \text { above } \\
\text { bottom }\end{array}$ & $\begin{array}{c}2 \text { m below } \\
\text { surface }\end{array}$ & $\begin{array}{c}2 \mathrm{~m} \text { above } \\
\text { bottom }\end{array}$ & $\begin{array}{c}2 \text { m below } \\
\text { surface }\end{array}$ & $\begin{array}{c}2 \mathrm{~m} \text { above } \\
\text { bottom }\end{array}$ & $\begin{array}{l}2 \text { m below } \\
\text { surface }\end{array}$ & $\begin{array}{c}2 \mathrm{~m} \text { above } \\
\text { bottom }\end{array}$ & $\begin{array}{l}2 \mathrm{~m} \text { below } \\
\text { surface }\end{array}$ & $\begin{array}{c}2 \mathrm{~m} \text { above } \\
\text { bottom }\end{array}$ \\
\hline \multicolumn{13}{|c|}{ Dissolved solids, in milligrams per liter } \\
\hline 1.0x (baseline) & 80.4 & 85.8 & 81.0 & 80.8 & 86.1 & 83.1 & 85.5 & 83.5 & 83.9 & 84.3 & 84.2 & 84.2 \\
\hline $1.2 \mathrm{x}$ & 91.7 & 94.2 & 90.9 & 90.0 & 91.5 & 88.5 & 90.9 & 88.2 & 88.1 & 88.1 & 87.1 & 87.4 \\
\hline $1.5 \mathrm{x}$ & 108 & 111 & 105 & 103 & 100 & 96.5 & 100 & 95.4 & 96 & 94.4 & 91.6 & 92.6 \\
\hline $2.0 \mathrm{x}$ & 134 & 142 & 129 & 126 & 115 & 110 & 137 & 108 & 107 & 105 & 99.0 & 101 \\
\hline $5.0 \mathrm{x}$ & 273 & 337 & 269 & 269 & 197 & 202 & 192 & 193 & 170 & 182 & 142 & 169 \\
\hline $10.0 \mathrm{x}$ & 485 & 671 & 477 & 524 & 313 & 367 & 304 & 344 & 258 & 327 & 206 & 307 \\
\hline \multicolumn{13}{|c|}{ Chloride, in milligrams per liter } \\
\hline 1.0x (baseline) & 3.22 & 3.50 & 3.38 & 3.48 & 4.30 & 4.07 & 4.22 & 4.11 & 4.00 & 4.14 & 4.00 & 4.09 \\
\hline $1.2 \mathrm{x}$ & 3.70 & 3.86 & 3.85 & 3.92 & 4.46 & 4.27 & 4.39 & 4.27 & 4.28 & 4.28 & 4.12 & 4.22 \\
\hline $1.5 \mathrm{x}$ & 4.38 & 4.48 & 4.43 & 4.43 & 4.83 & 4.57 & 4.75 & 4.54 & 4.47 & 4.51 & 4.30 & 4.43 \\
\hline $2.0 \mathrm{x}$ & 5.36 & 5.67 & 5.35 & 5.28 & 5.40 & 5.06 & 6.80 & 4.98 & 4.91 & 4.89 & 4.58 & 4.76 \\
\hline $5.0 \mathrm{x}$ & 10.8 & 13.3 & 10.8 & 10.8 & 8.63 & 8.55 & 8.37 & 8.19 & 7.37 & 7.80 & 6.26 & 7.34 \\
\hline $10.0 \mathrm{x}$ & 19.1 & 26.3 & 19.0 & 20.8 & 13.2 & 14.9 & 12.8 & 14.0 & 10.80 & 13.4 & 8.77 & 12.6 \\
\hline \multicolumn{13}{|c|}{ Sulfate, in milligrams per liter } \\
\hline 1.0x (baseline) & 11.3 & 11.4 & 10.5 & 9.87 & 8.80 & 8.69 & 8.79 & 8.76 & 8.75 & 8.88 & 8.90 & 8.93 \\
\hline $1.2 \mathrm{x}$ & 12.7 & 12.6 & 11.5 & 11.0 & 9.63 & 9.46 & 9.61 & 9.41 & 9.42 & 9.42 & 9.29 & 9.39 \\
\hline $1.5 \mathrm{x}$ & 15.0 & 15.6 & 13.6 & 13.0 & 10.9 & 10.6 & 10.8 & 10.5 & 10.4 & 10.3 & 9.92 & 10.1 \\
\hline $2.0 \mathrm{x}$ & 18.7 & 20.5 & 17.0 & 16.2 & 12.9 & 12.7 & 14.1 & 12.3 & 12.0 & 11.9 & 10.9 & 11.4 \\
\hline $5.0 \mathrm{x}$ & 39.4 & 50.2 & 37.2 & 37.3 & 24.3 & 25.9 & 23.7 & 24.5 & 20.5 & 22.9 & 16.8 & 21.0 \\
\hline $10.0 \mathrm{x}$ & 71.3 & 101 & 66.8 & 74.5 & 40.3 & 49.4 & 39.2 & 46.1 & 32.6 & 43.6 & 25.7 & 40.3 \\
\hline
\end{tabular}


Table 6. Average daily dissolved solids, chloride, and sulfate concentrations for baseline condition and increasing loading scenarios from War Eagle Creek (site S3) only, for the period January 2006 through December 2010, 2 meters ( $\mathrm{m}$ ) below the surface and $2 \mathrm{~m}$ above the bottom at model segments 48, 5, 14, 16, 23, and 35 (fig. 2).

[m, meter; $\mathrm{x}$, times]

\begin{tabular}{|c|c|c|c|c|c|c|c|c|c|c|c|c|}
\hline Loading factor & \multicolumn{2}{|c|}{$\begin{array}{c}\text { Segment } 2 \\
\text { (site L1) }\end{array}$} & \multicolumn{2}{|c|}{$\begin{array}{l}\text { Segment } 5 \\
\text { (site L2) }\end{array}$} & \multicolumn{2}{|c|}{$\begin{array}{c}\text { Segment } 14 \\
\text { (Site L10) }\end{array}$} & \multicolumn{2}{|c|}{$\begin{array}{l}\text { Segment } 16 \\
\text { (site L3) }\end{array}$} & \multicolumn{2}{|c|}{$\begin{array}{c}\text { Segment } 23 \\
\text { (site L4) }\end{array}$} & \multicolumn{2}{|c|}{$\begin{array}{l}\text { Segment } 35 \\
\text { (site L5) }\end{array}$} \\
\hline 1.0x (baseline) & 95.1 & 90.4 & 81.0 & 80.8 & 86.1 & 83.1 & 85.5 & 83.5 & 83.9 & 84.3 & 84.2 & 84.2 \\
\hline $1.2 \mathrm{x}$ & 102 & 97.3 & 82.6 & 83.9 & 90.4 & 88.0 & 89.8 & 87.8 & 87.8 & 87.8 & 86.7 & 87.0 \\
\hline $1.5 \mathrm{x}$ & 114 & 110 & 84.8 & 87.7 & 97.8 & 95.3 & 96.9 & 94.6 & 93.4 & 93.8 & 90.7 & 91.8 \\
\hline $10.0 \mathrm{x}$ & 309 & 463 & 166 & 262 & 264 & 348 & 259 & 325 & 222 & 296 & 190 & 293 \\
\hline \multicolumn{13}{|c|}{ Chloride, in milligrams per liter } \\
\hline 1.0x (baseline) & 5.64 & 5.15 & 3.38 & 3.48 & 4.30 & 4.07 & 4.22 & 4.11 & 4.00 & 4.14 & 4.00 & 4.09 \\
\hline $1.2 \mathrm{x}$ & 5.88 & 5.49 & 3.57 & 3.76 & 4.56 & 4.40 & 4.48 & 4.40 & 4.25 & 4.38 & 4.17 & 4.28 \\
\hline $1.5 \mathrm{x}$ & 6.71 & 6.39 & 3.72 & 4.01 & 5.05 & 4.90 & 4.95 & 4.87 & 4.61 & 4.80 & 4.42 & 4.61 \\
\hline 2.0x & 7.96 & 7.91 & 3.98 & 4.48 & 5.82 & 5.78 & 5.69 & 5.68 & 5.17 & 5.53 & 4.82 & 5.21 \\
\hline 1.0x (baseline) & 7.79 & 7.94 & 10.5 & 9.87 & 8.80 & 8.69 & 8.79 & 8.76 & 8.75 & 8.88 & 8.90 & 8.93 \\
\hline $1.2 \mathrm{x}$ & 8.53 & 8.51 & 10.2 & 9.81 & 9.08 & 8.90 & 9.06 & 8.93 & 8.98 & 9.01 & 9.03 & 9.07 \\
\hline $1.5 \mathrm{x}$ & 9.34 & 9.17 & 10.3 & 9.99 & 9.50 & 9.26 & 9.46 & 9.25 & 9.31 & 9.29 & 9.26 & 9.32 \\
\hline $2.0 \mathrm{x}$ & 10.5 & 10.3 & 10.5 & 10.3 & 10.2 & 9.90 & 10.1 & 9.84 & 9.83 & 9.81 & 9.63 & 9.74 \\
\hline $5.0 \mathrm{x}$ & 15.5 & 16.9 & 11.9 & 12.9 & 13.7 & 14.4 & 13.6 & 14.0 & 12.6 & 13.7 & 11.7 & 13.2 \\
\hline $10.0 \mathrm{x}$ & 20.8 & 28.0 & 14.6 & 19.1 & 18.7 & 22.8 & 18.4 & 21.6 & 16.6 & 20.0 & 14.8 & 20.0 \\
\hline
\end{tabular}


Table 7. Average daily dissolved solids, chloride, and sulfate concentrations for baseline condition and increasing loading factor scenarios from White River near Fayetteville (site S1) and War Eagle Creek near Hindsville (site S3), for the period January 2006 through December 2010, 2 meters (m) below the surface and $2 \mathrm{~m}$ above the bottom at model segments $2,5,14,16,23$, and 35 (fig. 2).

$[\mathrm{m}$, meter; $\mathrm{x}$, times]

\begin{tabular}{|c|c|c|c|c|c|c|c|c|c|c|c|c|}
\hline \multirow[b]{2}{*}{ Loading factor } & \multicolumn{2}{|c|}{$\begin{array}{c}\text { Segment } 2 \\
\text { (site L1) }\end{array}$} & \multicolumn{2}{|c|}{$\begin{array}{c}\text { Segment } 5 \\
\text { (site L2) }\end{array}$} & \multicolumn{2}{|c|}{$\begin{array}{c}\text { Segment } 14 \\
\text { (site L10) }\end{array}$} & \multicolumn{2}{|c|}{$\begin{array}{l}\text { Segment } 16 \\
\text { (site L3) }\end{array}$} & \multicolumn{2}{|c|}{$\begin{array}{l}\text { Segment } 23 \\
\text { (site L4) }\end{array}$} & \multicolumn{2}{|c|}{$\begin{array}{l}\text { Segment } 35 \\
\text { (site L5) }\end{array}$} \\
\hline & $\begin{array}{c}2 \mathrm{~m} \text { below } \\
\text { surface }\end{array}$ & $\begin{array}{c}2 \mathrm{~m} \text { above } \\
\text { bottom }\end{array}$ & $\begin{array}{c}2 \mathrm{~m} \text { below } \\
\text { surface }\end{array}$ & $\begin{array}{c}2 \mathrm{~m} \text { above } \\
\text { bottom }\end{array}$ & $\begin{array}{c}2 \mathrm{~m} \text { below } \\
\text { surface }\end{array}$ & $\begin{array}{c}2 \mathrm{~m} \text { above } \\
\text { bottom }\end{array}$ & $\begin{array}{c}2 \mathrm{~m} \text { below } \\
\text { surface }\end{array}$ & $\begin{array}{c}2 \mathrm{~m} \text { above } \\
\text { bottom }\end{array}$ & $\begin{array}{c}2 \text { m below } \\
\text { surface }\end{array}$ & $\begin{array}{c}2 \mathrm{~m} \text { above } \\
\text { bottom }\end{array}$ & $\begin{array}{c}2 \mathrm{~m} \text { below } \\
\text { surface }\end{array}$ & $\begin{array}{c}2 \mathrm{~m} \text { above } \\
\text { bottom }\end{array}$ \\
\hline \multicolumn{13}{|c|}{ Dissolved solids, in milligrams per liter } \\
\hline 1.0x (baseline) & 80.4 & 85.8 & 81.0 & 80.8 & 86.1 & 83.1 & 85.5 & 83.5 & 83.9 & 84.3 & 84.2 & 84.2 \\
\hline $1.2 \mathrm{x}$ & 92.2 & 94.9 & 92.3 & 92.3 & 96.5 & 93.0 & 95.7 & 92.3 & 92.5 & 91.7 & 89.8 & 92.2 \\
\hline $1.5 \mathrm{x}$ & 109 & 112 & 109 & 109 & 113 & 108 & 111 & 106 & 105 & 104 & 98.2 & 100 \\
\hline $2.0 \mathrm{x}$ & 136 & 145 & 136 & 136 & 140 & 132 & 137 & 128 & 125 & 124 & 112 & 118 \\
\hline $5.0 \mathrm{x}$ & 283 & 347 & 301 & 305 & 289 & 276 & 277 & 266 & 236 & 255 & 191 & 247 \\
\hline $10.0 \mathrm{x}$ & 512 & 697 & 570 & 607 & 513 & 524 & 489 & 498 & 403 & 465 & 315 & 455 \\
\hline \multicolumn{13}{|c|}{ Chloride, in milligrams per liter } \\
\hline 1.0x (baseline) & 3.22 & 3.50 & 3.38 & 3.48 & 4.30 & 4.07 & 4.22 & 4.11 & 4.00 & 4.14 & 4.00 & 4.09 \\
\hline $1.2 \mathrm{x}$ & 3.74 & 3.91 & 3.95 & 4.07 & 4.80 & 4.58 & 4.71 & 4.56 & 4.43 & 4.52 & 4.28 & 3.74 \\
\hline $1.5 \mathrm{x}$ & 4.45 & 4.58 & 4.67 & 4.82 & 5.66 & 5.36 & 5.53 & 5.28 & 5.07 & 5.18 & 4.71 & 4.95 \\
\hline $2.0 \mathrm{x}$ & 5.51 & 5.87 & 5.84 & 6.04 & 7.01 & 6.63 & 6.80 & 6.46 & 6.07 & 6.20 & 5.40 & 5.86 \\
\hline $5.0 \mathrm{x}$ & 11.5 & 14.0 & 12.9 & 13.4 & 14.6 & 14.1 & 13.9 & 13.6 & 11.5 & 13.1 & 9.33 & 12.7 \\
\hline $10.0 \mathrm{x}$ & 20.7 & 28.0 & 24.6 & 26.7 & 25.9 & 26.5 & 24.5 & 25.2 & 19.8 & 23.9 & 15.5 & 23.4 \\
\hline \multicolumn{13}{|c|}{ Sulfate, in milligrams per liter } \\
\hline 1.0x (baseline) & 11.3 & 11.4 & 10.5 & 9.87 & 8.80 & 8.69 & 8.79 & 8.76 & 8.75 & 8.88 & 8.90 & 8.93 \\
\hline $1.2 \mathrm{x}$ & 12.7 & 12.6 & 11.6 & 11.1 & 9.92 & 9.65 & 9.88 & 9.59 & 9.63 & 9.58 & 9.45 & 12.7 \\
\hline $1.5 \mathrm{x}$ & 15.0 & 15.7 & 13.8 & 13.2 & 11.6 & 11.1 & 11.5 & 10.9 & 10.9 & 10.7 & 10.3 & 10.5 \\
\hline $2.0 \mathrm{x}$ & 18.8 & 20.6 & 17.4 & 16.6 & 14.3 & 13.5 & 14.1 & 13.1 & 13.0 & 12.6 & 11.7 & 12.2 \\
\hline $5.0 \mathrm{x}$ & 40.2 & 50.5 & 39.2 & 38.4 & 29.8 & 27.8 & 28.6 & 26.3 & 24.5 & 25.0 & 19.6 & 24.0 \\
\hline $10.0 \mathrm{x}$ & 73.2 & 102 & 73.8 & 77.2 & 52.9 & 53.3 & 50.3 & 50.2 & 41.6 & 46.6 & 32.2 & 43.7 \\
\hline
\end{tabular}



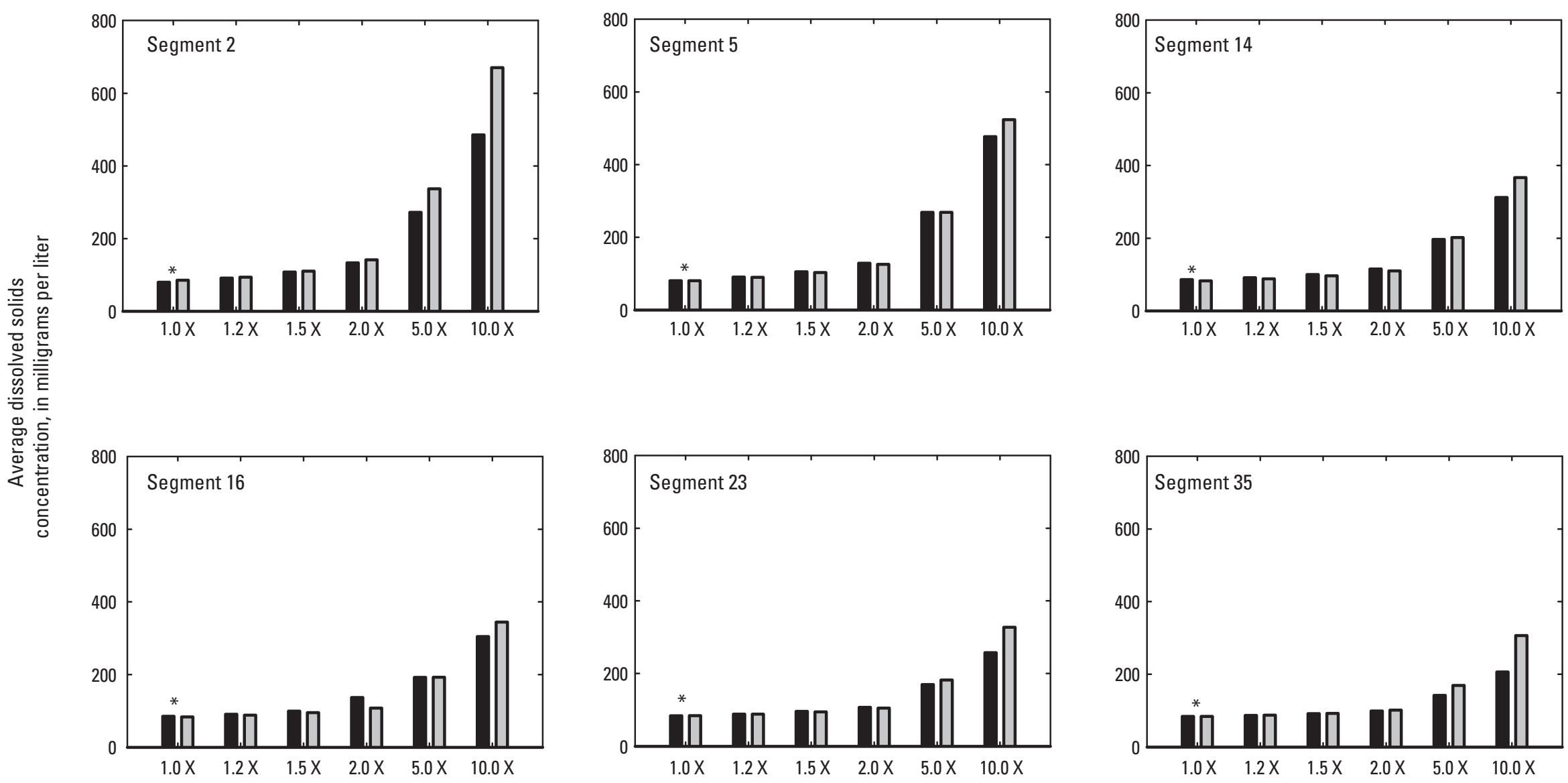

White River near Fayetteville (site S1) loading factor

\section{EXPLANATION}

2 meters below surface

$\square 2$ meters above bottom

Figure 18. Average daily dissolved solids for the period January 2006 through December 2010 at 2 meters $(\mathrm{m})$ below the surface and $2 \mathrm{~m}$ above the bottom at model segments 2 , $5,14,16,23$, and 35 from baseline model (loading factor 1.0) and increased loading factor scenarios (1.2, 1.5, 2.0, 5.0, and 10.0) from White River near Fayetteville, Arkansas, (site S1) only. ( ${ }^{*}$ Fayetteville wastewater treatment plant dissolved solids not included in CE-QUAL-W2 baseline calibration or any scenario runs.) 

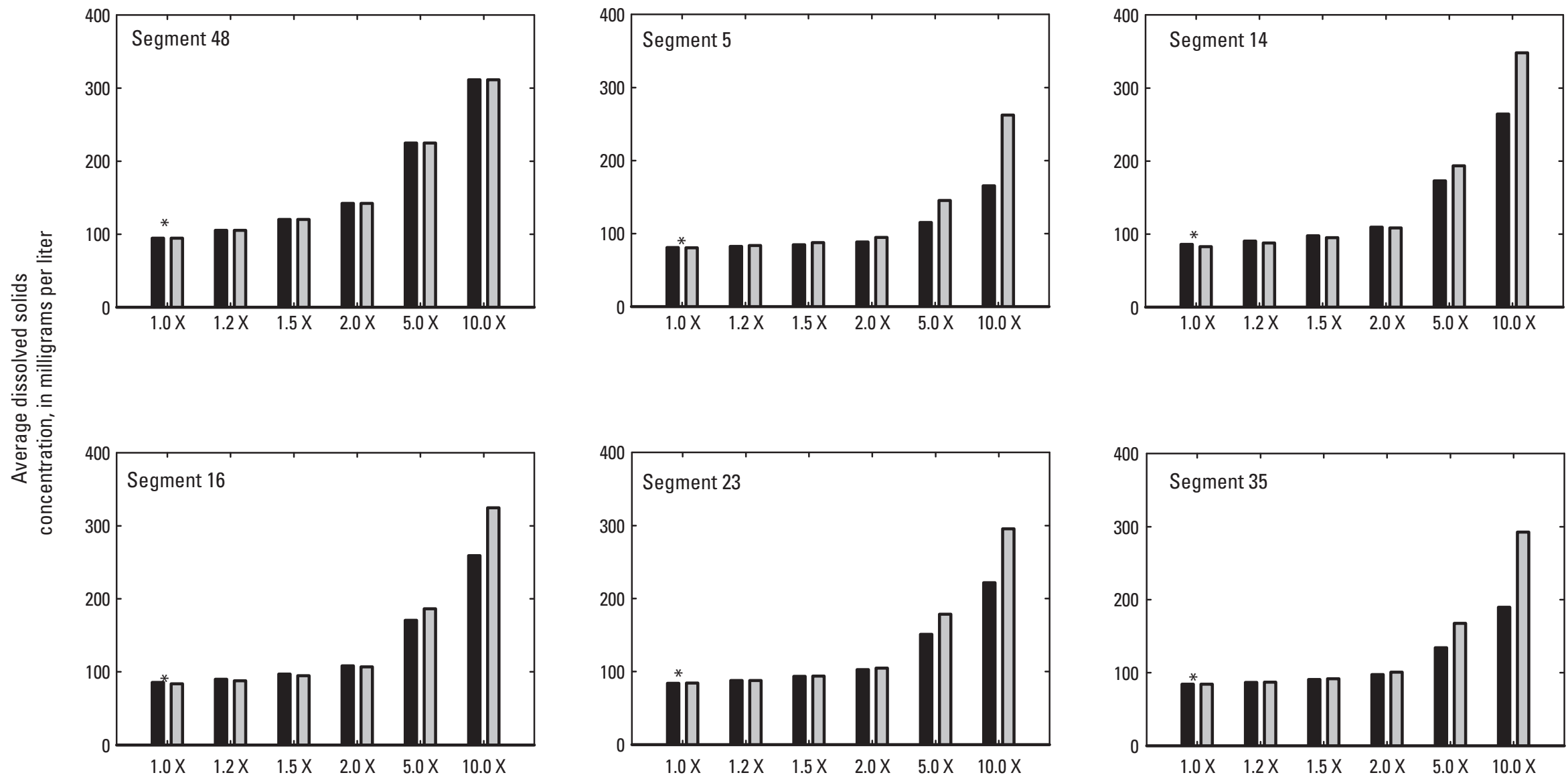

War Eagle Creek near Hindsville (site S3) loading factor

\section{EXPLANATION}

2 meters below surface
2 meters above bottom

Figure 19. Average daily dissolved solids for the period January 2006 through December 2010 at 2 meters (m) below the surface and $2 \mathrm{~m}$ above the bottom at model segments $48,5,14,16,23$, and 35 from baseline model (loading factor 1.0) and increased loading factor scenarios (1.2, 1.5, 2.0, 5.0, and 10.0) from War Eagle Creek near Hindsville, Arkansas, (site S3) only. ( ${ }^{*}$ Fayetteville wastewater treatment plant dissolved solids not included in CE-QUAL-W2 baseline calibration or any scenario runs.) 

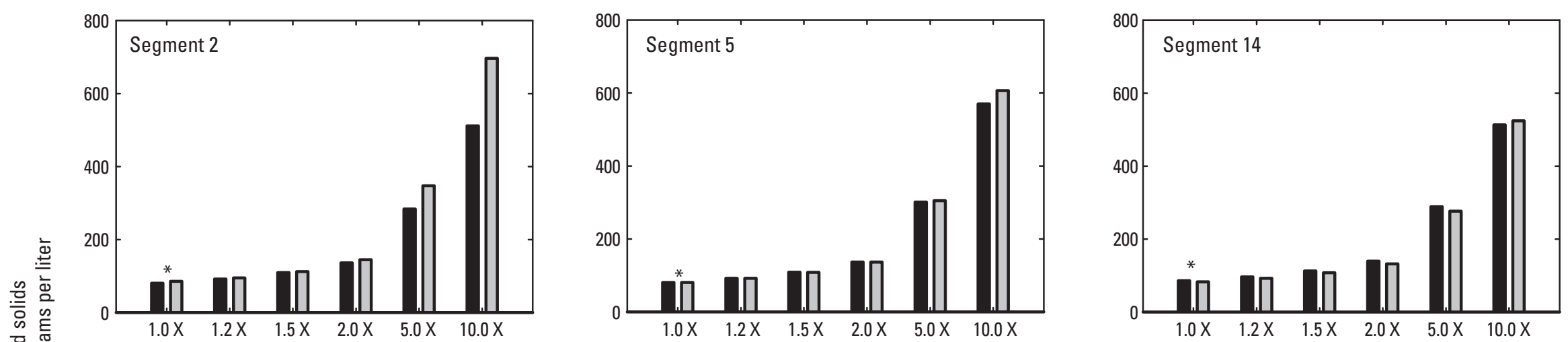

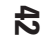
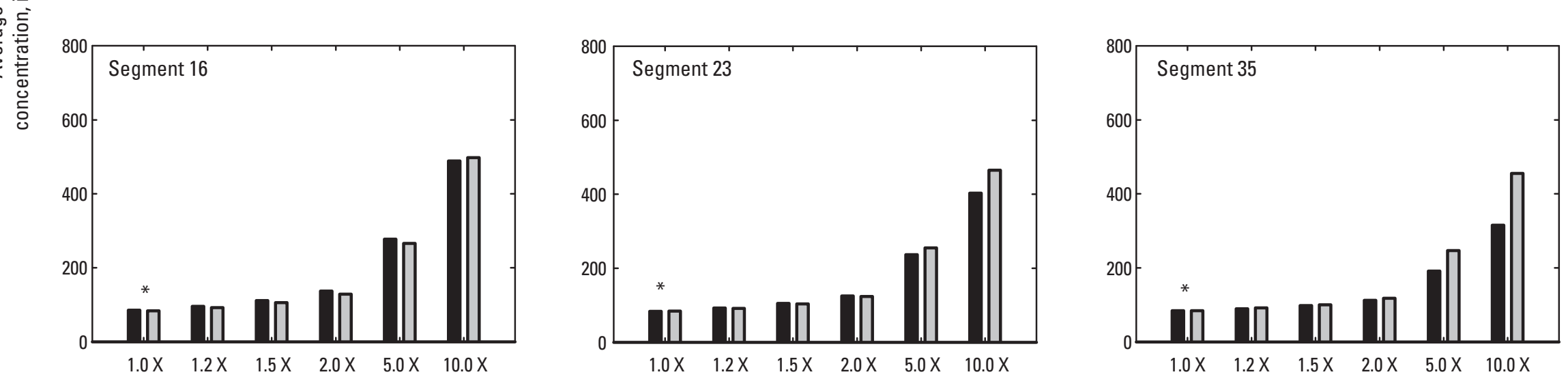

White River near Fayetteville (site S1) and War Eagle Creek near Hindsville (site S3) concurrent loading factor

\section{EXPLANATION}

2 meters below surface

$\square 2$ meters above bottom

Figure 20. Average daily dissolved solids for the period January 2006 through December 2010 at 2 meters below the surface and 2 meters above the bottom at model segments $2,5,14,16,23$, and 35 from baseline model (loading factor 1.0) and increased loading factor scenarios (1.2, 1.5, 2.0, 5.0, and 10.0) from both White River near Fayetteville, Arkansas, (site S1) and War Eagle Creek near Hindsville, Ark. (site S3). (* Fayetteville wastewater treatment plant dissolved solids not included in CE-QUAL-W2 baseline calibration or any scenario runs.) 

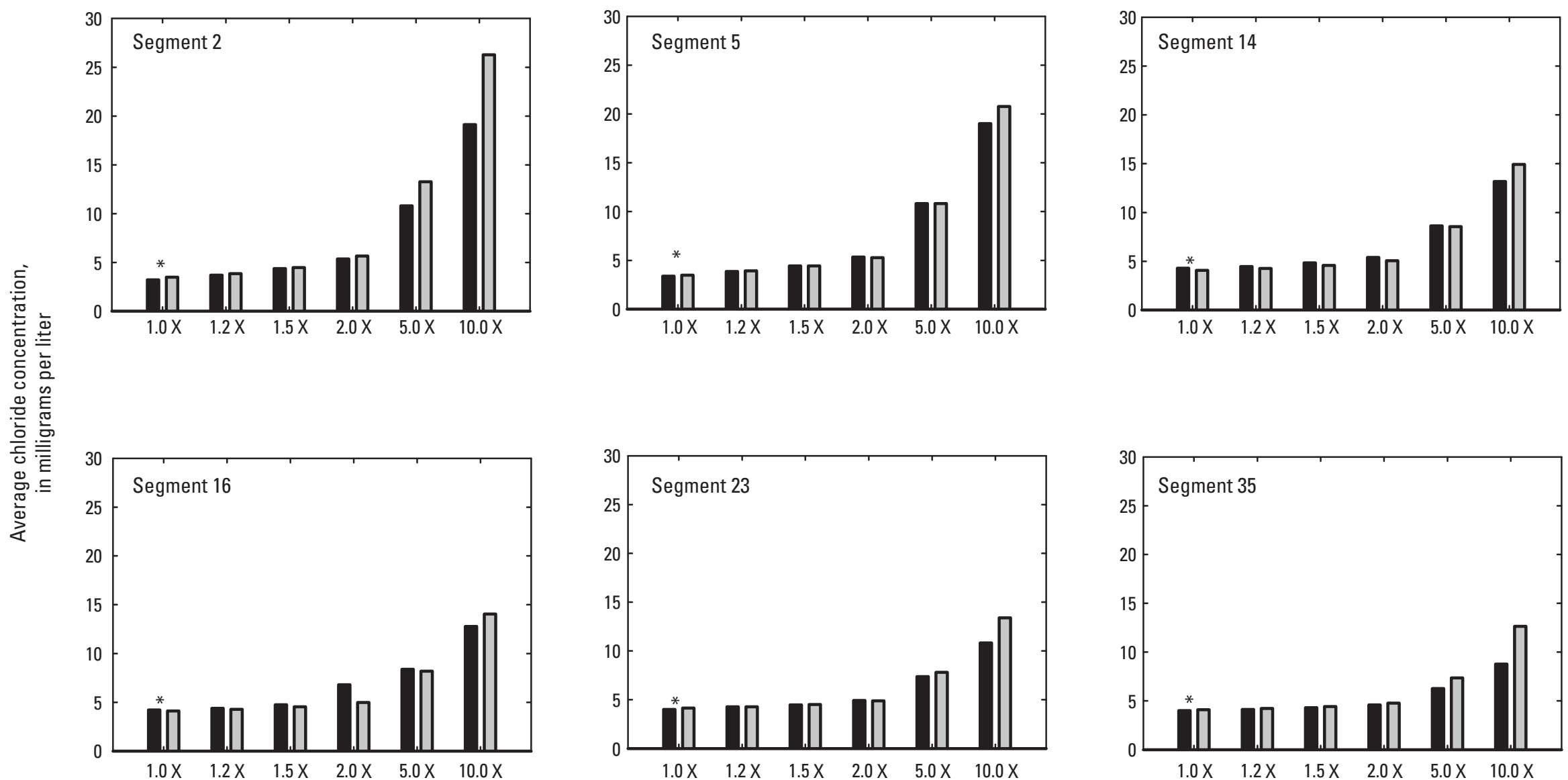

White River near Fayetteville (site S1) loading factor

\section{EXPLANATION}

2 meters below surface

$\square 2$ meters above bottom

Figure 21. Average daily chloride concentrations for the period January 2006 through December 2010 at 2 meters below the surface and 2 meters above the bottom at model segments 2, 5, 14, 16, 23, and 35 from baseline model (loading factor 1.0) and increased loading factor scenarios $(1.2,1.5,2.0,5.0$, and 10.0) from White River near Fayetteville, Arkansas, (site S1) only. (* Fayetteville wastewater treatment plant chloride load not included in CE-QUAL-W2 baseline calibration or any scenario runs.) 

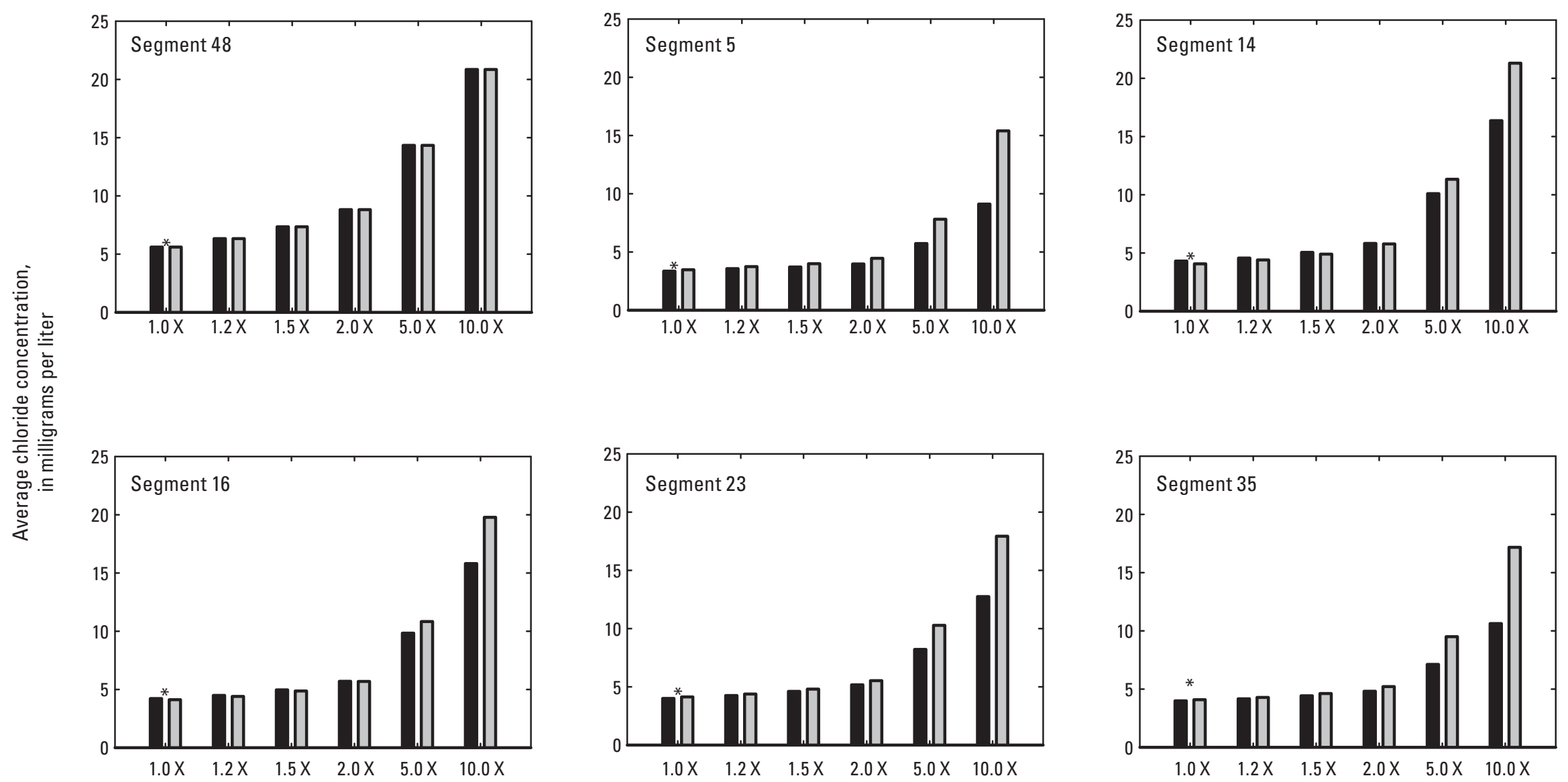

$\$$
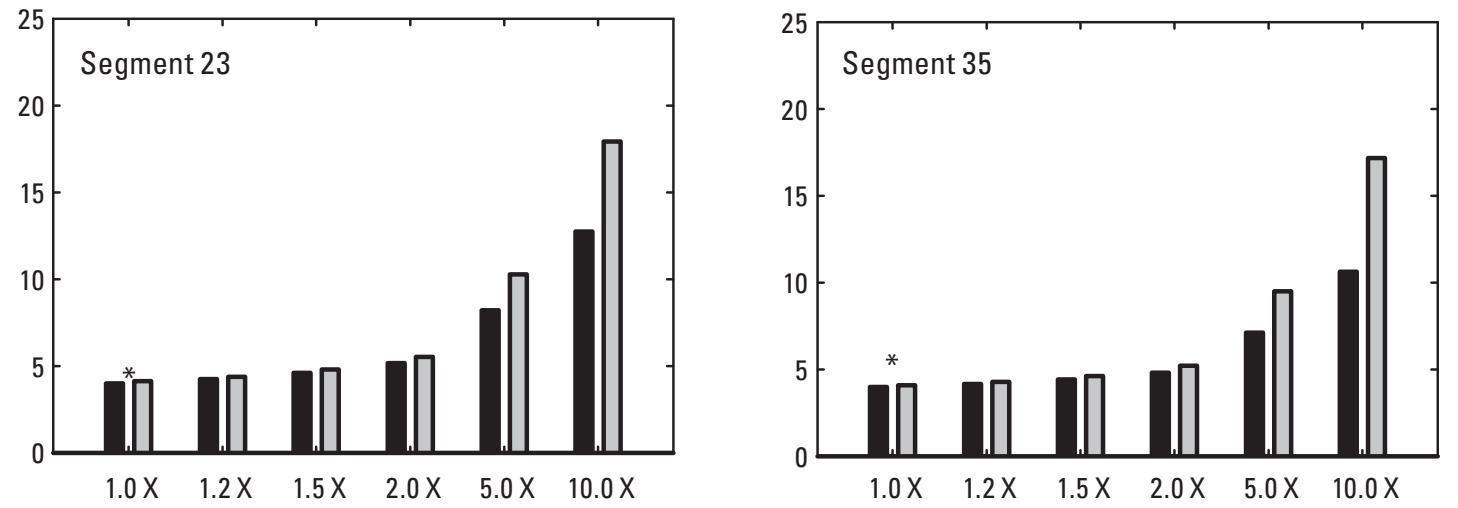

War Eagle Creek near Hindsville (site S3) loading factor

\section{EXPLANATION}

2 meters below surface

2 meters above bottom

Figure 22. Average daily chloride concentrations for the period January 2006 through December 2010 at 2 meters below the surface and 2 meters above the bottom at model segments 48, 5, 14, 16, 23, and 35 from baseline model (loading factor 1.0) and increased loading factor scenarios (1.2, 1.5, 2.0, 5.0, and 10.0) from War Eagle Creek near Hindsville, Arkansas, (site S3) only. ( ${ }^{*}$ Fayetteville wastewater treatment plant chloride load not included in CE-QUAL-W2 baseline calibration or any scenario runs.) 

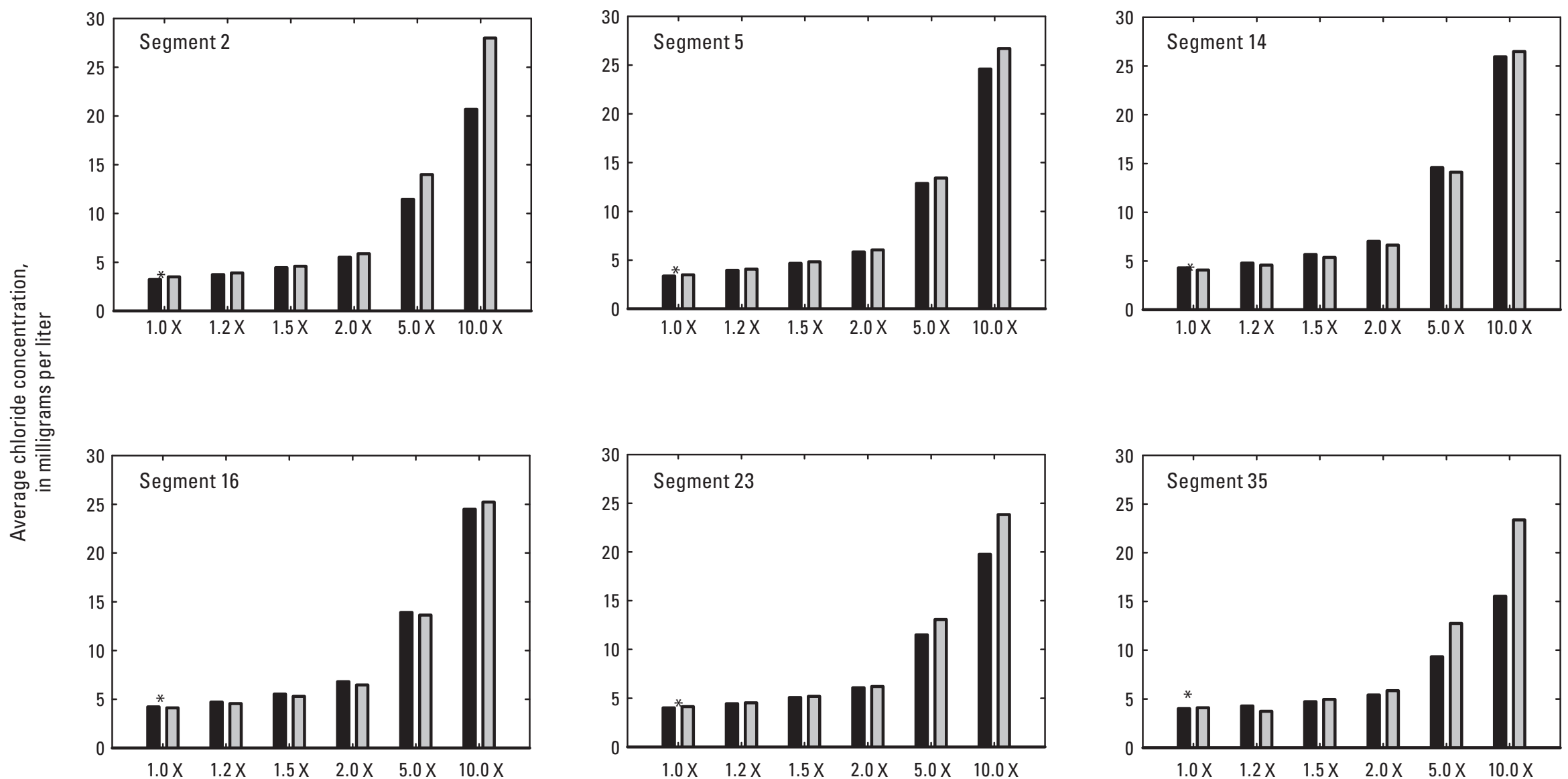

White River near Fayetteville (site S1) and War Eagle Creek near Hindsville (site S3) concurrent loading factor

\section{EXPLANATION}

2 meters below surface

$\square 2$ meters above bottom

Figure 23. Average daily chloride concentrations for the period January 2006 through December 2010 at 2 meters below the surface and 2 meters above the bottom at model segments 2, 5, 14, 16, 23, and 35 from baseline model (loading factor 1.0) and increased loading factor scenarios (1.2, 1.5, 2.0, 5.0, and 10.0) from both White River near Fayetteville, Arkansas, (site S1) and War Eagle Creek near Hindsville, Ark. (site S3). ( ${ }^{*}$ Fayetteville wastewater treatment plant chloride load not included in CE-QUAL-W2 baseline calibration or any scenario runs.) 

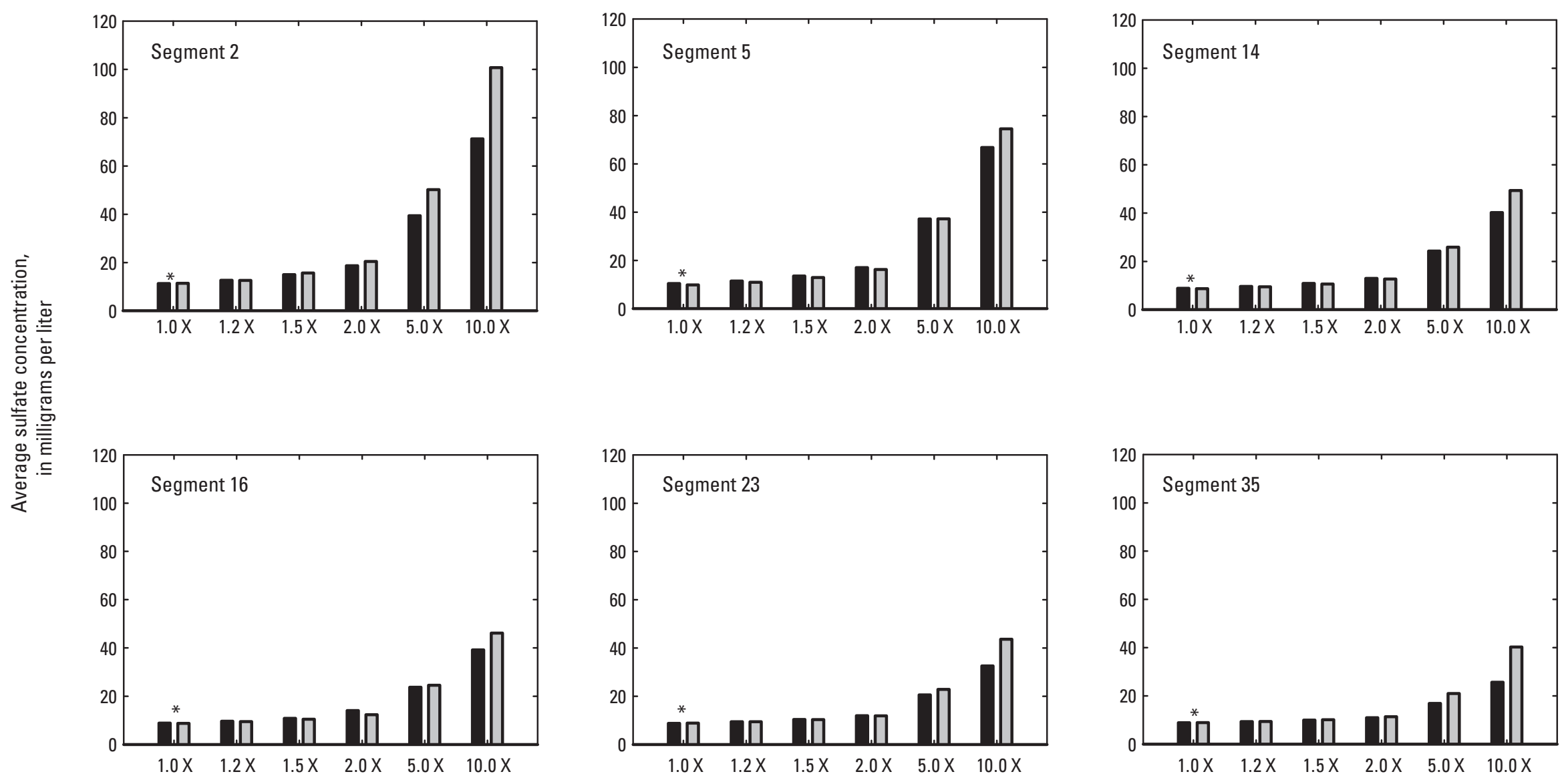

White River near Fayetteville (site S1) loading factor

\section{EXPLANATION}

2 meters below surface
2 meters above bottom

Figure 24. Average daily sulfate concentrations for the period January 2006 through December 2010 at 2 meters below the surface and 2 meters above the bottom at model segments 2, 5, 14, 16, 23, and 35 from baseline model (loading factor 1.0) and increased loading factor scenarios (1.2, 1.5, 2.0, 5.0, and 10.0) from White River near Fayetteville, Arkansas, (site S1) only. (* Fayetteville wastewater treatment plant sulfate load not included in CE-QUAL-W2 baseline calibration or any scenario runs.) 

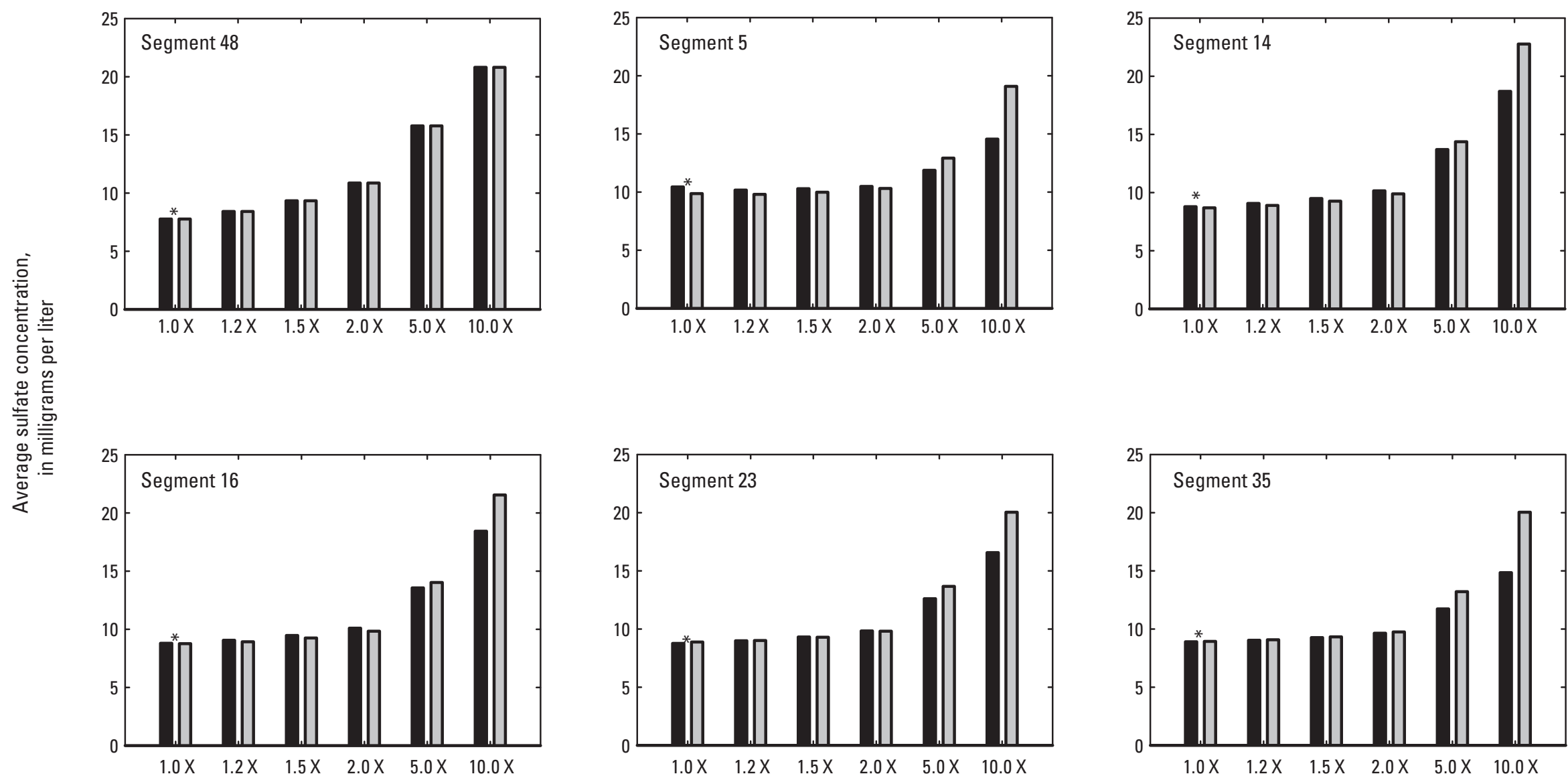

War Eagle Creek near Hindsville (site S3) loading factor

\section{EXPLANATION}

2 meters below surface

$\square 2$ meters above bottom

Figure 25. Average daily sulfate concentrations for the period January 2006 through December 2010 at 2 meters below the surface and 2 meters above the bottom at model segments 48, 5, 14, 16, 23, and 35 from baseline model (loading factor 1.0) and increased loading factor scenarios (1.2, 1.5, 2.0, 5.0, and 10.0) from War Eagle Creek near Hindsville, Arkansas, (site S3) only. (* Fayetteville wastewater treatment plant sulfate load not included in CE-QUAL-W2 baseline calibration or any scenario runs.) 

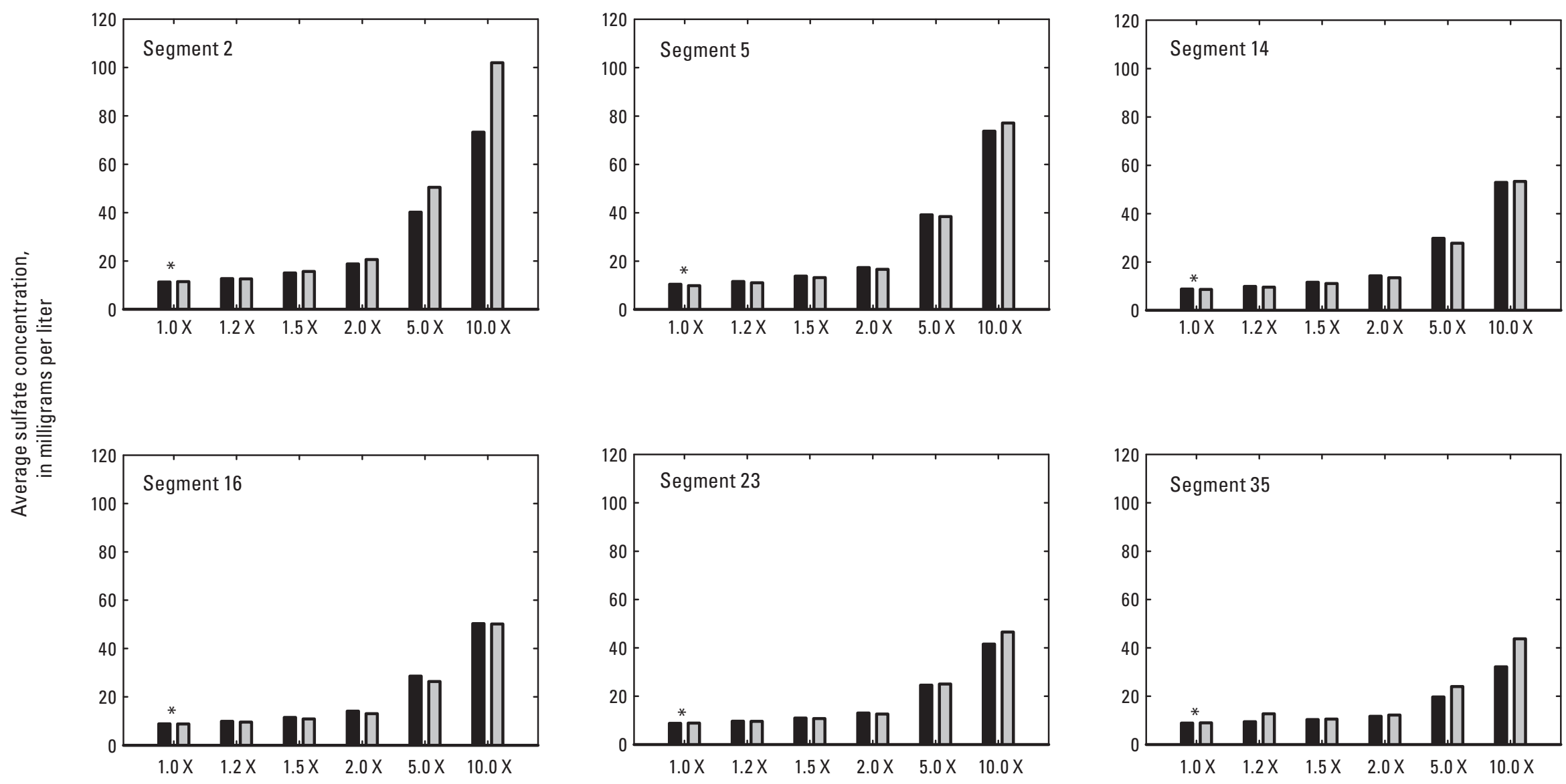

White River near Fayetteville (site S1) and War Eagle Creek near Hindsville (site S3) concurrent loading factor

\section{EXPLANATION}

2 meters below surface

2 meters above bottom

Figure 26. Average daily sulfate concentrations for the period January 2006 through December 2010 at 2 meters below the surface and 2 meters above the bottom at model segments 2, 5, 14, 16,23, and 35 from baseline model (loading factor 1.0) and increased loading factor scenarios (1.2, 1.5, 2.0, 5.0, and 10.0) from both White River near Fayetteville, Arkansas, (site S1) and War Eagle Creek near Hindsville, Ark. (site S3). (* Fayetteville wastewater treatment plant sulfate load not included in CE-QUAL-W2 baseline calibration or any scenario runs.) 


\section{Summary}

Beaver Lake is a large, deep-storage reservoir located in the upper White River Basin in northwestern Arkansas, and was completed in 1963 for the purposes of flood control, hydroelectric power, and water supply. In addition, the reservoir is used for fish and wildlife habitat, recreation, and waste assimilation. Beaver Lake is affected by point and nonpoint sources of minerals, nutrients, and sediments. The City of Fayetteville discharges about half of its sewage effluent into the White River immediately upstream from the backwater of the reservoir. The City of West Fork discharges its sewage effluent into the West Fork of the White River, and the City of Huntsville discharges its sewage effluent into a tributary of War Eagle Creek.

The purpose of this report is to describe the ambient conditions and fate and transport of dissolved solids, chloride, and sulfate concentrations in Beaver Lake. Dissolved solids, chloride, and sulfate are components of wastewater discharged into Beaver Lake and a major concern of the drinking water utilities that use Beaver Lake as their source. A twodimensional model of hydrodynamics and water quality was calibrated to include simulations of dissolved solids, chloride, and sulfate for the period January 2006 through December 2010. Estimated daily dissolved solids, chloride, and sulfate loads were increased in the White River and War Eagle Creek tributaries, individually and the two tributaries together, by $1.2,1.5,2.0,5.0$, and 10.0 times the baseline conditions to examine fate and transport of these constituents through time at seven locations in the reservoir, from upstream to downstream in Beaver Lake.

Fifteen dissolved solids, chloride, and sulfate fate and transport scenarios were compared to the baseline simulation at each of the seven downstream locations in the reservoir, both 2 meters $(\mathrm{m})$ below the surface and $2 \mathrm{~m}$ above the bottom. Concentrations were greater in the reservoir at model segments closer to where the tributaries entered the reservoir. Concentrations resulting from the increase in loading became more diluted farther downstream from the source. Differences in concentrations between the baseline condition and the $1.2,1.5$, and 2.0 times baseline concentration scenarios were smaller than the differences in the 5.0 and 10.0 times baseline concentration scenarios. The results for both the $2 \mathrm{~m}$ below the surface and $2 \mathrm{~m}$ above the bottom were similar, with the exception of concentrations resulting from the increased loading factors (5.0 and 10.0 times), where concentrations 2 $\mathrm{m}$ above the bottom were consistently greater than those $2 \mathrm{~m}$ below the surface at most segments.

\section{Cited References}

Bales, J.D., Sarver, K.M., and Giorgino, M.J., 2001, Mountain Island Lake, North Carolina-Analysis of ambient conditions and simulation of hydrodynamics, constituent transport, and water-quality characteristics, 1996-97: U.S. Geological Survey Water-Resources Investigations Report 01-4138, 85 p.

Cohn, T.A., 1995, Recent advances in statistical methods for the estimation of sediment and nutrient transport in rivers, U.S. National Report to the International Union Geodesy and Geophysics, 1991-1994: Reviews of Geophysics, supplement 33, p. 1117-1123.

Cohn, T.A., Caulder, D.L., Gilroy, E.J., Zynjuk, L.D., and Summers, R.M., 1992, The validity of a simple log-linear model for estimating fluvial constituent loads - An empirical study involving nutrient loads entering Chesapeake Bay: Water Resources Research, v. 28, no. 9, p. 2353-2363.

Cole, T.M., and Wells, S.A., 2003, CEQUAL-W2-A two dimensional, laterally averaged, hydrodynamic and water quality model, version 3.1: U.S. Army Corps of Engineers Instruction Report EL-03-1 [variously paged].

Fishman, M.J., 1993, Methods of analysis by the U.S. Geological Survey National Water Quality Laboratory-Determination of inorganic and organic constituents in water and fluvial sediments: U.S. Geological Survey Open-File Report 93-125, $217 \mathrm{p}$.

Galloway, J.M., and Green, W.R., 2002, Simulation of hydrodynamics, temperature, and dissolved oxygen in Norfork Lake, Arkansas, 1994-1995: U.S. Geological Survey WaterResources Investigations Report 02-4250, 23 p.

Galloway, J.M., and Green, W.R., 2003, Simulation of hydrodynamics, temperature, and dissolved oxygen in Bull Shoals Lake, Arkansas, 1994-1995: U.S. Geological Survey WaterResources Investigations Report 03-4077, 23 p.

Galloway, J.M, and Green, W.R. 2006, Analysis of ambient conditions and simulation of hydrodynamics and waterquality characteristics in Beaver Lake, Arkansas, 20012003: U.S. Geological Survey Scientific Investigations Report 2006-5003, 55 p.

Green, W.R., Galloway, J.M., Richards, J.M., and Wesolowski, E.A., 2003, Simulation of hydrodynamics, temperature, and dissolved oxygen in Table Rock Lake, Missouri, 1996-1997: U.S. Geological Survey Water-Resources Investigations Report 03-4237, 35 p. 
Haggard, B.E., and Green, W.R., 2002, Simulation of hydrodynamics, temperature, and dissolved oxygen in Beaver Lake, Arkansas, 1994-1995: U.S. Geological Survey WaterResources Investigations Report 02-4116, 21 p.

Marciano, J.J., and Harbeck, G.E., 1954, Mass-transfer studies, in Water-loss investigations-Lake Hefner studies, technical report: U.S. Geological Survey Professional Paper 269, p. 46-70.

Rantz, S.E, and others, 1982, Measurement and computation of streamflow-Volume 1. Measurement of stage and discharge, Volume 2. Computation of discharge: U.S. Geological Survey Water-Supply Paper 2175, 631 p.

Runkel, R.L., Crawford, C.G., and Cohn, T.A., 2004, Load estimator (LOADEST) - A FORTRAN program for estimating constituent loads in streams and rivers: U.S. Geological Survey Techniques and Methods, book 4, chap. A5, 69 p.

Sullivan, A.B., and Rounds, S.A., 2005, Modeling hydrodynamics, temperature, and water quality in Henry Hagg Lake, Oregon, 2000-03: U.S. Geological Survey Scientific Investigations Report 2004-5261, 38 p.

U.S. Army Corps of Engineers, 1997, Hydrologic engineering requirements for reservoirs: U.S. Army Corps of Engineers Engineering Manual 1110-2-1420 [variously paged].
Wilde, F.D., and Radke, D.B., 1998, Field measurements: U.S. Geological Survey Techniques of Water-Resources Investigations, book 9, chap. A6 [variously paged].

Wilde, F.D., Radke, D.B., Gibs, J., and Iwatsubo, R.T., 1998a, Preparations for water sampling: U.S. Geological Survey Techniques of Water-Resources Investigations, book 9, chap. A1 [variously paged].

Wilde, F.D., Radke, D.B., Gibs, J., and Iwatsubo, R.T., 1998b, Selection of equipment for water sampling: U.S. Geological Survey Techniques of Water-Resources Investigations, book 9, chap. A2 [variously paged].

Wilde, F.D., Radke, D.B., Gibs, J., and Iwatsubo, R.T., 1998c, Cleaning of equipment for water sampling: U.S. Geological Survey Techniques of Water-Resources Investigations, book 9, chap. A3 [variously paged].

Wilde, F.D., Radke, D.B., Gibs, J., and Iwatsubo, R.T., 1999a, Collection of water samples: U.S. Geological Survey Techniques of Water-Resources Investigations, book 9, chap. A4 [variously paged].

Wilde, F.D., Radke, D.B., Gibs, J., and Iwatsubo, R.T., 1999b, Processing of water samples: U.S. Geological Survey Techniques of Water-Resources Investigations, book 9, chap. A5 [variously paged]. 
